\title{
42. MIOCENE TO EARLY PLIOCENE OXYGEN AND CARBON ISOTOPE STRATIGRAPHY IN THE SOUTHWEST PACIFIC, DEEP SEA DRILLING PROJECT LEG 901
}

\author{
James P. Kennett, Graduate School of Oceanography, University of Rhode Island
}

\begin{abstract}
High-resolution oxygen and carbon isotope stratigraphy is presented for Miocene to early Pliocene sequences at three DSDP sites from the Lord Howe Rise, southwest Pacific, at water depths ranging from 1,300 to 2,000 m. Site 588 is located in the warm subtropics $\left(\sim 26^{\circ} \mathrm{S}\right)$, whereas Sites 590 and 591 are positioned in transitional (northern temperate) water masses $\left(\sim 31^{\circ} \mathrm{S}\right)$. Benthic foraminiferal oxygen and carbon isotope analyses were conducted on all sites; planktonic foraminiferal isotope data were generated for Site 590 only. Sample resolution in these sequences is on the order of $50,000 \mathrm{yr}$. or better. The chronological framework employed in this study is based largely upon ages assigned to Neogene calcareous nannoplankton boundaries.

The benthic oxygen isotope record exhibits several major features during the Neogene. During most of the early Miocene, $\delta^{18} \mathrm{O}$ values were relatively low, reaching minimum values in the late early Miocene (19.5 to $\left.16.5 \mathrm{Ma}\right)$, and recording the climax of Neogene warmth. This was followed by a major increase in benthic $\delta^{18} \mathrm{O}$ values between $\sim 16.5$ and $13.5 \mathrm{Ma}$, which is interpreted as representing major, permanent accumulation of the East Antarctic ice sheet and cooling of bottom waters. During the $3 \mathrm{~m} . \mathrm{y} .{ }^{18} \mathrm{O}$ enrichment, surface waters at these middle latitudes warmed between 16 and $14.5 \mathrm{Ma}$.

During the remainder of the middle and late Miocene, benthic $\delta^{18} \mathrm{O}$ values exhibit distinct fluctuations, but the average value remained unchanged. The isotopic data show two distinct episodes of climatic cooling close to the middle/late Miocene boundary. The earliest of these events occurred between 12.5 and $11.5 \mathrm{Ma}$ in the latest middle Miocene. The second cooling event occurred from 11 to $9 \mathrm{Ma}$, and is marked by some of the highest $\delta^{18} \mathrm{O}$ values of the entire Miocene. This was followed by relative warmth during the middle part of the late Miocene. The latest Miocene and earliest Pliocene (6.2 to $4.5 \mathrm{Ma})$ were marked by relatively high $\delta^{18} \mathrm{O}$ values, indicating increased cooling and glaciation.

During the middle Pliocene, at about $3.4 \mathrm{Ma}$, a $0.4 \%$ increase in benthic $\delta^{18} \mathrm{O}$ documents a net increase in average global ice volume and cooling of bottom waters. During this interval of increased glaciation, surface waters warmed by $2-3^{\circ} \mathrm{C}$ in southern middle-latitude regions. During the late Pliocene, between 2.6 and $2.4 \mathrm{Ma}$, a further increase in $\delta^{18} \mathrm{O}$ occurred; this has been interpreted by previous workers as heralding the onset of Northern Hemisphere glaciation.

Surface-water warming in the middle latitudes occurred in association with major high-latitude glacial increases in the early middle Miocene $(16-14 \mathrm{Ma})$, middle Pliocene $(\sim 3.5 \mathrm{Ma})$, and late Pliocene $(\sim 2.4 \mathrm{Ma})$. These intervals were also marked by increases in the vertical temperature gradient in the open ocean.

Intersite correlation is enhanced by using carbon isotope stratigraphy. The great similarity of the $\delta^{13} \mathrm{C}$ time-series records within and between ocean basins and with water depth clearly indicates that changes in oceanwide average $\delta^{13} \mathrm{C}$ of $\mathrm{HCO}_{3}^{-}$in seawater dominated the records, rather than local effects. Broad changes in the Neogene $\delta^{13} \mathrm{C}$ record were caused largely by transfer of organic carbon between continental and oceanic reservoirs. These transfers were caused by marine transgressions and regressions on the continental margins.

The dominant feature of Neogene $\delta^{13} \mathrm{C}$ stratigraphy is a broad late early to early middle Miocene increase of about $1 \%$ between $\sim 19$ and $14.5 \mathrm{Ma}$. This trend occurred contemporaneously with a period of maximum coastal onlap (transgression) and maximum Neogene climatic warmth. The $\delta^{13} \mathrm{C}$ trend terminated during the expansion of the Antarctic ice sheet and associated marine regression.

The latest Miocene carbon isotope shift (of up to $-0.75 \%$ ) at $6.2 \mathrm{Ma}$ is clearly recorded in all sites examined and was followed by relatively low values during the remainder of the Neogene. This shift was caused by a glacioeustatic sealevel lowering that exposed continental margins via regression and ultimately increased the flux of organic carbon to the deep sea. An increase in $\delta^{13} \mathrm{C}$ values during the early Pliocene ( $\sim 5$ to $4 \mathrm{Ma}$ ) resulted from marine transgression during a time of global warmth.
\end{abstract}

\section{INTRODUCTION}

Cenozoic cooling, which began in the middle Eocene, proceeded gradually, but was punctuated by sudden transitions from one climatic state to another. Global climate underwent major changes during the Miocene Epoch. The most important change occurred during the early middle Miocene, between $\sim 17$ and 14 Ma. A marked increase in $\delta^{18} \mathrm{O}$ of benthic foraminiferal calcite at this time is commonly interpreted as recording the

\footnotetext{
${ }^{1}$ Kennett, J. P., von der Borch, C. C., et al., Init. Repts. DSDP, 90: Washington (U.S. Govt, Printing Office).

School of Oceanography, University of Rhode Island, Narragansett, R.I. $92882-1197$.
}

rapid growth of the East Antarctic ice sheet and associated cooling of high-latitude surface and deep-ocean waters (Savin et al., 1975; Shackleton and Kennett, 1975b; Kennett, 1977; Schnitker, 1980; Keigwin, 1979; Woodruff et al., 1981; Savin et al., 1981). Others have interpreted this increase in $\delta^{18} \mathrm{O}$ values as reflecting only a decrease in bottom-water temperatures, unaccompanied by any increase in Antarctic ice (Matthews and Poore, 1980).

Oxygen isotope ratios of benthic and planktonic foraminifers indicate that these events were accompanied by a marked increase in the equator-to-pole thermal gradient and an associated decrease in meridional heat transport (Savin et al., 1975, in press). Tropical Pacific nearsurface temperatures increased while high-latitude regions 


\section{J. P. KENNETT}

cooled as Antarctic ice volume increased during the middle Miocene (Savin et al., in press). Increased latitudinal temperature gradients are recorded by the progressive divergence of tropical planktonic and benthic foraminiferal $\delta^{18} \mathrm{O}$ curves caused by increasing vertical temperature stratification. The early Miocene was marked by limited Antarctic glaciation, gentler equator-to-pole and tropical surface-to-bottom temperature gradients, and warmer high-latitude surface waters. This early Miocene ocean contrasts sharply with that of the late Miocene, which was more similar to the modern ocean (Matthews et al., 1980).

The primary objective of DSDP Leg 90 was to study the Cenozoic paleoceanographic and paleoclimatic evolution of the South Pacific, with emphasis on the Neogene. A latitudinal traverse of carbonate-rich Neogene sequences was cored during Leg 90 on the Lord Howe Rise and New Zealand Platform. Since these sedimentary sequences were obtained using the hydraulic piston corer (HPC) and the extended core barrel (XCB), they are relatively continuous and undisturbed, and are of great value for studies of high-resolution stratigraphy and paleoceanography. HPC sequences in the relatively soft carbonate ooze that blankets this shallow southwest Pacific region were longer than $200 \mathrm{~m}$ in each site studied. At Site 588, the HPC sequence is $315 \mathrm{~m}$ thick, the longest ever obtained. This sequence contains a continuous, largely uninterrupted record spanning the past 17 m.y. from the late early Miocene to the Quaternary.

This paper presents a detailed study of oxygen and carbon isotope stratigraphy during the Miocene and early Pliocene in three of the Leg 90 sites: 588, 590, and 591 (Fig. 1; Table 1). A number of features of strati- graphic value were identified in the isotopic records of these continuous, high-resolution sequences. The stratigraphic resolution in these sites is much higher than obtained in previous investigations and thus allows a more detailed examination of Miocene paleoceanographic and paleoclimatic history than was previously possible. This paper describes major trends in the isotopic data and discusses causal mechanisms underlying the changes. Future work will consider detailed correlation of the stable isotope records and further examination of cause/effect relationships.

\section{Site Descriptions}

The locations of the three sites are shown in Figure 1, with additional relevant information provided in Table 1. The three sequences are composed of relatively uniform, light-colored, foraminifer-bearing to foraminiferrich nannofossil oozes to chalks throughout the Miocene and Pliocene. Calcium carbonate content is greater than $90 \%$ throughout, the terrigenous sedimentary components are virtually nonexistent. Preservation of foraminiferal assemblages is good to excellent in all sections, and deposition always occurred at depths shallower than the foraminiferal lysocline (Kennett and von der Borch, this volume). A noticeable decrease in the quality of preservation of planktonic foraminifers occurs in chalks of early Miocene age at Site 590 and of early middle and early Miocene age at Site 591 . Some planktonic foraminiferal specimens from these intervals are slightly recrystallized, but benthic foraminifers show no such change.

Rates of sedimentation show marked changes during the Neogene (Gardner, Dean, et al., this volume). Each of the sites exhibits similar trends. Average early Mio-

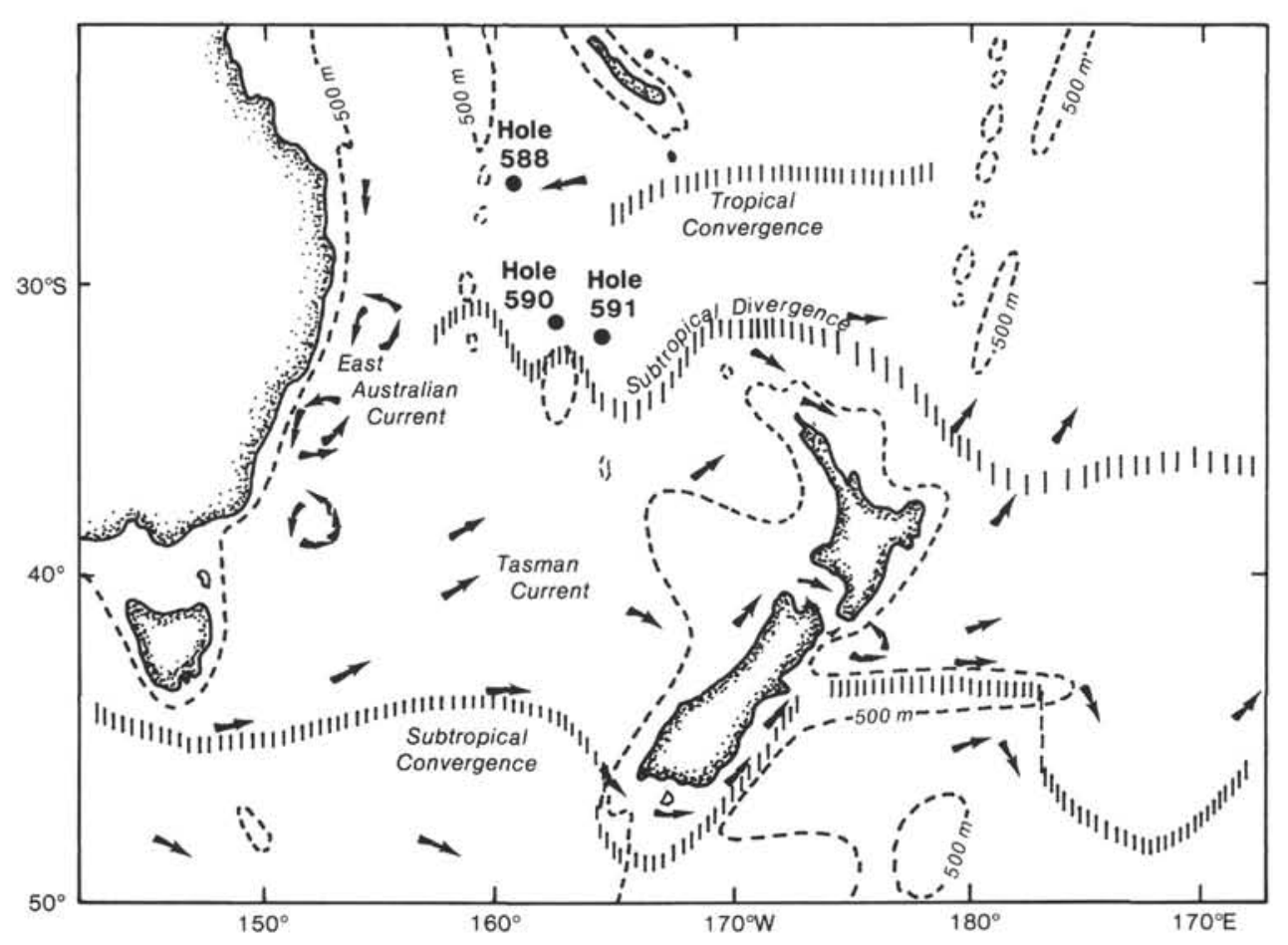

Figure 1. Location of Sites 588, 590, and 591 in relation to modern surface-water boundaries and general circulation in the southwest Pacific (Knox, 1970; Wyrtki, 1974). Dashed line indicates $500 \mathrm{~m}$ isobath. 
Table 1. Data for sites analyzed in this chapter.

\begin{tabular}{|c|c|c|c|}
\hline & Site 588 & Site 590 & Site 591 \\
\hline Latitude (S) & $26^{\circ} 06.70^{\prime}$ & $31^{\circ} 10.02^{\prime}$ & $31^{\circ} 35.06^{\prime}$ \\
\hline Longitude (E) & $161^{\circ} 13.60^{\prime}$ & $163^{\circ} 21.51^{\prime}$ & $164^{\circ} 26.92^{\prime}$ \\
\hline Water depth (m) & 1533 & 1299 & 2131 \\
\hline Modern water mass & Warm-subtropical & $\begin{array}{l}\text { Cool-subtropical to } \\
\text { transitional }\end{array}$ & $\begin{array}{l}\text { Cool-subtropical to } \\
\text { transitional }\end{array}$ \\
\hline $\begin{array}{l}\text { Thickness of Miocene } \\
\text { sequence drilled (m) }\end{array}$ & 288 & 306 & 316 \\
\hline $\begin{array}{l}\text { Depth at which XCB sub- } \\
\text { stituted for HPC (m) }\end{array}$ & 248.6 & 250.7 & 283.1 \\
\hline $\begin{array}{l}\text { Depth of ooze/chalk } \\
\text { transition }(\mathrm{m})\end{array}$ & 260 & 283.1 & 290 \\
\hline
\end{tabular}

cene ( 23 to $16 \mathrm{Ma})$ carbonate accumulation rates for the open ocean were relatively constant $\left(4.9 \mathrm{~g} / \mathrm{cm}^{2}\right.$ per $10^{3}$ yr.). Accumulation rates were much more variable from about 15 to $10 \mathrm{Ma}$ (middle Miocene) reaching a peak (up to $13 \mathrm{~g} / \mathrm{cm}^{2}$ per $10^{3} \mathrm{yr}$.) at approximately $12 \mathrm{Ma}$. The late Miocene to earliest Pliocene (10 to $4 \mathrm{Ma}$ ) was marked by fairly constant and average rates of accumulation (Gardner, Dean, et al., this volume). At about $5 \mathrm{Ma}$, near the Miocene/Pliocene boundary, accumulation rates again increased, and widespread, shortlived, remarkably high accumulation rates (up to $27 \mathrm{~g} / \mathrm{cm}^{2}$ per $10^{3}$ yr.) occurred between 4 and $3 \mathrm{Ma}$ (late early Pliocene). This does not simply reflect an artifact of the time scale, because a major modification of the time scale would be required substantially to change the pattern of increased sedimentation rates. Relatively high rates of sedimentation during this interval have also been reported elsewhere for areas such as the Columbia Basin and the Caribbean Sea (Prell, Gardner, et al., 1982). These high rates during the late early Pliocene were particularly pronounced at Sites 590 and 591 and were due to high productivity of calcareous biogenic material (site chapters, this volume), related to the position of the Subtropical Divergence (Tasman Front) that crosses the Tasman Sea in the vicinity of Sites 590 and 591 (Fig. 1). Sedimentation rates are much lower to the north (Site 588 ) and south (Site 592). Accumulation rates during the late Pliocene were much lower than in the early Pliocene, but remained higher than average Neogene rates.

\section{Oceanographic Setting}

The physical oceanography has not been studied in much detail in the region of the three sites used in this study (Fig. 1). Knox (1970) and Wyrtki (1974) showed the position of the major surface-water masses and their boundaries, and directions of surface-water flow in the region (Fig. 1). Site 588 lies within the warm-subtropical water mass, whereas Sites 590 and 591 lie close to the present-day position of the Subtropical Divergence (Tasman Front) that separates warm-subtropical and temperate water masses (Denham and Crook, 1976; Stanton, 1979, 1981). The Subtropical Divergence represents the southern extent of the South Pacific subtropical gyre as the East Australian Current turns to the east, passing to the north of the barrier formed by New Zealand. Upwelling at the Subtropical Divergence is caused by the divergence of the two surface-water masses and the interaction of the eastward-flowing gyral circulation with the Lord Howe Rise (Stanton, 1981). This has created high biogenic sedimentation rates, which in the late Neogene ranged up to $131 \mathrm{~m} / \mathrm{m}$.y. at Site 591, the site closest to the Divergence.

Sites 588 and 590 are located in similar water depths, 1500 and $1300 \mathrm{~m}$, respectively, yet bottom-water temperatures at Site 590 are $0.5^{\circ} \mathrm{C}$ warmer (Site $588=3.75^{\circ} \mathrm{C}$; Site $590=4.25^{\circ} \mathrm{C}$ ), because of the eastward passage across this area of the warm waters contained in the subtropical gyre.

The sites on the Lord Howe Rise have moved about $5^{\circ}$ to the north during the Neogene as the result of the movement of the Indo-Australian Plate (Sclater et al., in press). The northward movement of these sites into warmer waters during the Neogene should be reflected by planktonic assemblages indicative of increasingly warm surface water and by lower planktonic $\delta^{18} \mathrm{O}$ values, unless the water masses themselves changed latitudinal positions.

\section{Stratigraphy and Chronology}

Rich calcareous microfossil assemblages facilitated biostratigraphic subdivision of the sequences. Calcareous nannoplankton and planktonic foraminiferal zonal boundaries are from Lohman (this volume) and Jenkins and Srinivasan (this volume), as summarized in the Introduction (this volume). The nannoplankton zonal boundaries were determined using uneven sample spacing ranging from a few $\mathrm{cm}$ to up to $8 \mathrm{~m}$, resulting in varying precision in the placement of individual zonal boundaries. Planktonic foraminiferal zonal boundaries were determined by examining core-catcher samples only (i.e., at $9 \mathrm{~m}$ stratigraphic intervals). Minor adjustments were made on zonal boundary positions in the late Miocene and Pliocene of Site 590, as discussed by Elmstrom and Kennett (this volume).

The chronological framework employed here is based upon ages assigned to Neogene calcareous nannoplankton zonal (NN) boundaries (Table 2) by Berggren (1981), and the scheme was uniformly applied by the Leg 90 scientific group (Introduction, this volume). I have also adopted an age of $6.2 \mathrm{Ma}$ for the NN11a/11b boundary. The chronology of the latest Miocene through early Quaternary of Site 590 was that used by Elstrom and Kennett (this volume), with some minor modifications from the scheme used by the Leg 90 group. The chronological

Table 2. Ages assigned to boundaries between nannofossil NN zones to establish chronological framework in this paper.

\begin{tabular}{cccr}
\hline NN zones & Ma & NN zones & Ma \\
\hline NN19/20 & 0.55 & NN10/11a & 9.50 \\
$18 / 19$ & 1.90 & $9 / 10$ & 11.00 \\
$17 / 18$ & 2.30 & $8 / 9$ & 12.00 \\
$16 / 17$ & 2.40 & $7 / 8$ & 12.20 \\
$15 / 16$ & 3.45 & $6 / 7$ & 13.00 \\
$14 / 15$ & 3.65 & $5 / 6$ & 15.00 \\
$13 / 14$ & 4.10 & $4 / 5$ & 17.00 \\
$12 / 13$ & 4.60 & $3 / 4$ & 17.80 \\
$11 \mathrm{~b} / 12$ & 5.20 & $2 / 3$ & 19.00 \\
$11 \mathrm{a} / 11 \mathrm{~b}$ & 6.20 & $1 / 2$ & 20.50 \\
\hline
\end{tabular}


intercalibration used by Berggren (1981) and most other workers for the past 10 years is based upon a correlation between Chron 9 and Anomaly 5. This scheme places the middle/late Miocene boundary at $11 \mathrm{Ma}$. After Leg 90 was completed, a major adjustment to the Neogene time scale was made by Berggren, Kent, and Van Couvering (1985), based upon a correlation between Chron 11 and Anomaly 5 (Barron et al., in press). If this correlation is accepted, then an age of 8.92 to 10.42 Ma must be assigned to Chron 11 in accordance with the Berggren, Kent, and Flynn (1985) paleomagnetic time scale. In this scheme, the middle Miocene/late Miocene boundary, which is correlated with upper Chron 11, is assigned an age of $9.5 \mathrm{Ma}$ (Barron et al., in press). This change also requires a shift of about 1.5 to $2 \mathrm{~m}$.y. toward younger ages for much of the late Miocene and late middle Miocene. Nevertheless, to maintain consistency among the Leg 90 contributions, the older time scale is employed here.

All three sites contain continuous sedimentary sequences except for an unconformity at $456 \mathrm{~m}$ at Site 590. This unconformity contains the interval from the upper part of the Globorotalia miozea Zone (late early Miocene) to the lower part of the $G$. fohsi s.l. Zone (early middle Miocene). The calcareous nannoplankton do not indicate an unconformity at this level, but suggest instead the NN4 and part of NN5 are missing at $470.3 \mathrm{~m}$. In this study I recognize the hiatus at $456 \mathrm{~m}$ and place its age between about 18 and $16.5 \mathrm{Ma}$ (latest early Miocene).

Sample intervals for the isotopic analyses in the three sites were, for the most part, evenly spaced at $75 \mathrm{~cm}$ (Appendix). The quantity of time represented between samples varies according to changes in sedimentation rates. For much of the Miocene, sedimentation rates ranged from 1.5 to $3 \mathrm{~cm} / 10^{3} \mathrm{yr}$, which provides a sampling interval of about $25 \times 10^{3} \mathrm{yr}$. In the Pliocene, sedimentation rates were much higher, ranging from about 5 to $13 \mathrm{~cm} / 10^{3} \mathrm{yr}$. This provides a sampling interval of about 5 to $15 \times 10^{3} \mathrm{yr}$. Sampling intervals for isotope analyses are smaller than those used to define the positions of the calcareous nannoplankton boundaries and hence the isotope record is of higher resolution than the chronological framework.

\section{METHODS}

Samples were disaggregated by soaking in buffered Calgon solution, washed over a $63 \mu \mathrm{m}$ sieve, and oven-dried at $50^{\circ} \mathrm{C}$.

Isotopic analyses were performed on the planktonic foraminifers of the Globigerinoides immaturus-G. quadrilobatus-G. sacculifera lineage in Site 590 in the $295-412 \mu \mathrm{m}$ fraction. The relatively small size fraction was used to minimize the effect of size on isotopic variability (Berger et al., 1978; Killingley et al., 1981).

Isotopic analyses were performed on four benthic species $(>150 \mu \mathrm{m}$ size fraction) because no species extends throughout the entire Miocene (Appendix). Cibicidoides coryelli or Oridorsalis umbonatus were analyzed in the lower portion of the section, incorporating part of the early Miocene; $C$. wuellerstorf $i$ was analyzed in the middle part of the section and $C$. kullenbergi in the upper part of the sequence. The middle part of the sequence of Site 591 was analyzed using either $C . k u l-$ lenbergi or C. wuellerstorfi. Cibicidoides wuellerstorfi and C. kullenbergi have been shown to be isotopically indistinguishable within analytical error. The isotopic systematics of Cibicidoides spp. and Oridorsalis spp. have been discussed by Savin et al. (1981) and Loutit, Kennett, et al., (1983). C. wuellerstorfi deposits its test near carbon isotopic equilibrium, but Oridorsalis is $1.06 \%$ lower in $\delta^{13} \mathrm{C}$ than $C$. wuellerstorfi (Savin et al., 1981). With respect to $\delta^{18} \mathrm{O}, \mathrm{C}$. wuellerstor$f i$ deposits its test out of oxygen isotopic equilibrium by $0.72 \%$, whereas Oridorsalis is closer to equilibrium $(-0.03 \%$ ) (Savin et al., 1981).

Almost all analyses in this study were performed on Cibicidoides spp. No adjustments were made to the data for disequilibrium effects known for this genus. Because only a few measurements were made on Oridorsalis spp., the values of this form were adjusted relative to Cibicidoides by adding $+1.06 \%$ for $\delta^{13} \mathrm{C}$ and subtracting 0.72 for $\delta^{18} \mathrm{O}$ as suggested by Savin et al. (1981).

Specimens selected for isotopic analysis were ultrasonically cleaned in reagent-grade methanol and roasted in vacuo at $400^{\circ} \mathrm{C}$ for $1 \mathrm{hr}$. The samples were then reacted in $100 \%$ orthophosphoric acid at $50^{\circ} \mathrm{C}$. The evolved $\mathrm{CO}_{2}$ was purified by distilling four times and was analyzed for ${ }^{18} \mathrm{O} /{ }^{16} \mathrm{O}$ and ${ }^{13} \mathrm{C} /{ }^{12} \mathrm{C}$ ratios using an on-line VG Micromass 602D mass spectrometer. The analytical precision of the mass spectrometer is $\pm 0.1 \%$ for both $\delta^{18} \mathrm{O}$ and $\delta^{13} \mathrm{C}$, which is based upon the analyses of a laboratory standard of powdered B-1 (Orchardo, in the Appendix to Murphy and Kennett, this volume). This standard was analyzed at the beginning and end of each day. All isotopic results are expressed as per mil difference from PDB.

\section{RESULTS}

All isotopic results are presented in the Appendix. For each of the sites, the isotopic data were plotted against both depth and age and a three-point running average of the isotopic data was plotted against age. For Site 588, the data are plotted in Figures 2, 3, and 4; for Site 590 in Figures 5, 6, and 7; and for Site 591 in Figures 8, 9 , and 10 .

\section{Site 588}

\section{Benthic Foraminiferal Oxygen Isotopes}

The main features of Miocene benthic oxygen isotope records are exhibited by Figures 3 and 4. During the early Miocene, a slow, progressive decrease in $\delta^{18} \mathrm{O}$ values (apparent warming) occurred, reaching several minima (maximum isotopic temperatures) during the late early Miocene between about 19.5 and $17 \mathrm{Ma}$. Within this interval of optimal Neogene warmth, an episode of slightly higher $\delta^{18} \mathrm{O}$ values (apparent cooling) occurred between 19 and $18 \mathrm{Ma}$.

From $17 \mathrm{Ma}$ (latest early Miocene) to about $13.5 \mathrm{Ma}$ (middle middle Miocene), $\delta^{18} \mathrm{O}$ values increased by about $1.5 \%$. This increase, recognized in most deep-sea sedimentary sections, represents a shift in average values of about $1 \% 0$ from the early Miocene to the late Miocene.

From about $13.5 \mathrm{Ma}$ (middle middle Miocene) to about $4 \mathrm{Ma}$ (early Pliocene), the benthic $\delta^{18} \mathrm{O}$ values remained permanently offset, but exhibit no apparent long-term trends. There were, however, significant fluctuations during this interval. Within this 13.5 to $4 \mathrm{Ma}$ interval, episodes interpreted as having been warmer and with less polar ice occurred between about 13 and $12 \mathrm{Ma}$ (late middle Miocene), 7.5 and 6.2 (middle late Miocene), and 5.2 and $4 \mathrm{Ma}$ (early Pliocene). Episodes interpreted as having been cooler and with more polar ice occurred from about 11 to $10 \mathrm{Ma}$ (earliest late Miocene) and 6.2 to $5.2 \mathrm{Ma}$ (latest Miocene).

\section{Benthic Foraminiferal Carbon Isotopes}

The Miocene benthic carbon isotope record (Figs. 3 and 4) exhibits both short-term and long-term variabili- 
MIOCENE TO PLIOCENE ISOTOPE STRATIGRAPHY, SOUTHWEST PACIFIC

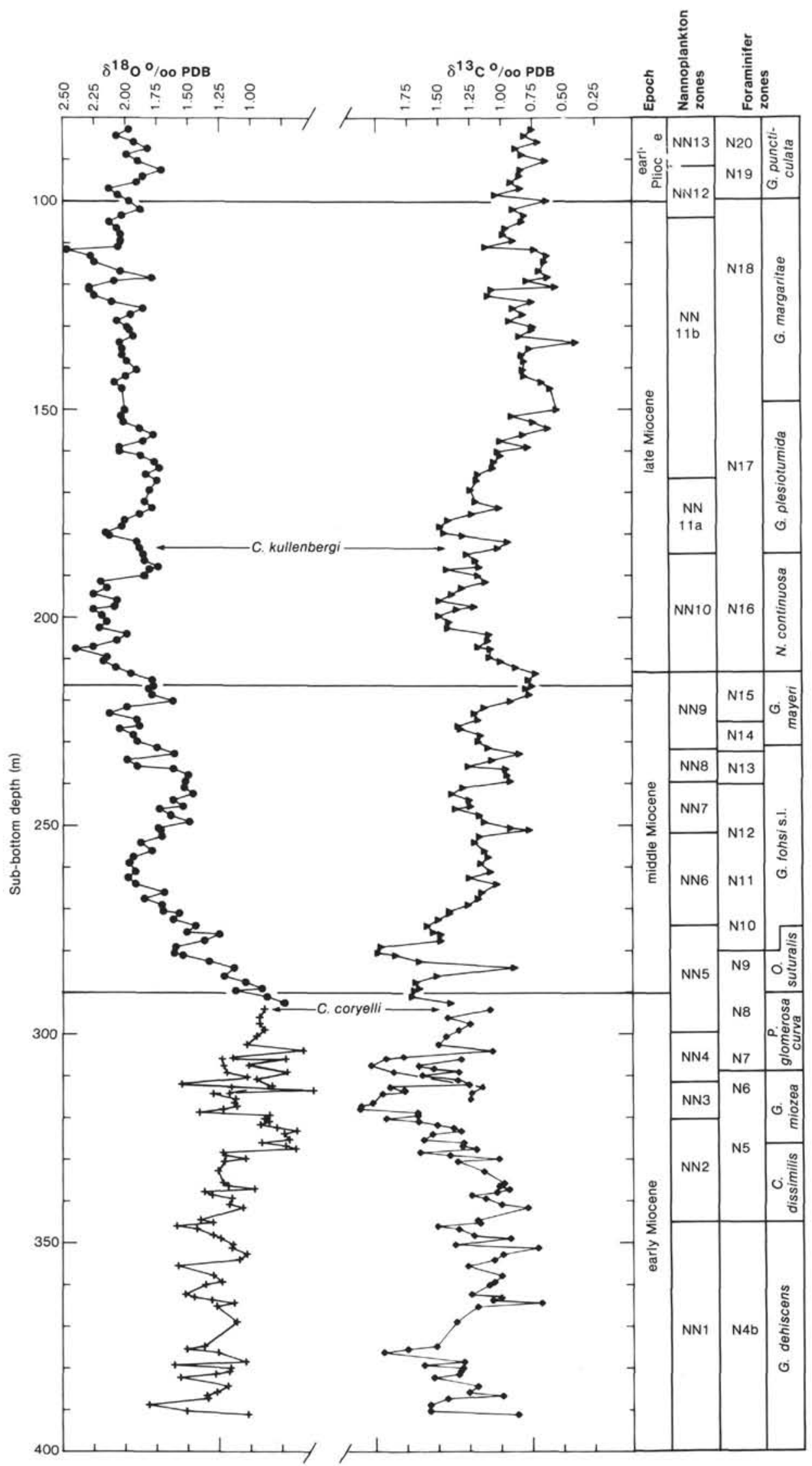

Figure 2. Benthic $\delta^{18} \mathrm{O}$ and $\delta^{13} \mathrm{C}$ for Holes $588,588 \mathrm{~A}$, and $588 \mathrm{C}$ plotted against depth at Site 588 and biostratigraphic zonations for calcareous nannoplankton (Lohman, this volume) and planktonic foraminifers (Jenkins and Srinivasan, this volume). 


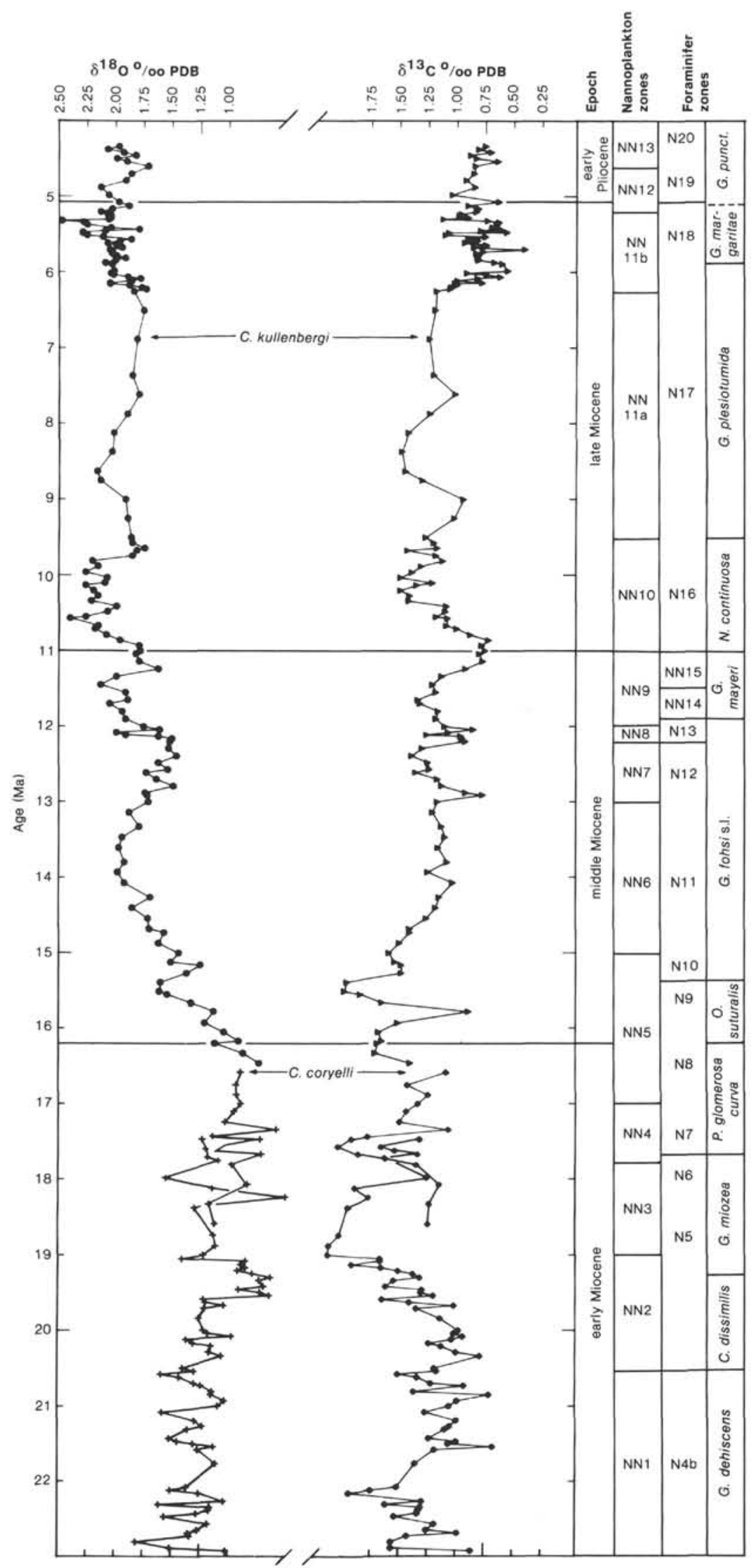

Figure 3. Benthic $\delta^{18} \mathrm{O}$ and $\delta^{13} \mathrm{C}$ for Holes $588,588 \mathrm{~A}$, and $588 \mathrm{C}$ plotted against age at Site 588 and biostratigraphic zonations for calcareous nannoplankton (Lohman, this volume) and planktonic foraminifers (Jenkins and Srinivasan, this volume). 
MIOCENE TO PLIOCENE ISOTOPE STRATIGRAPHY, SOUTHWEST PACIFIC

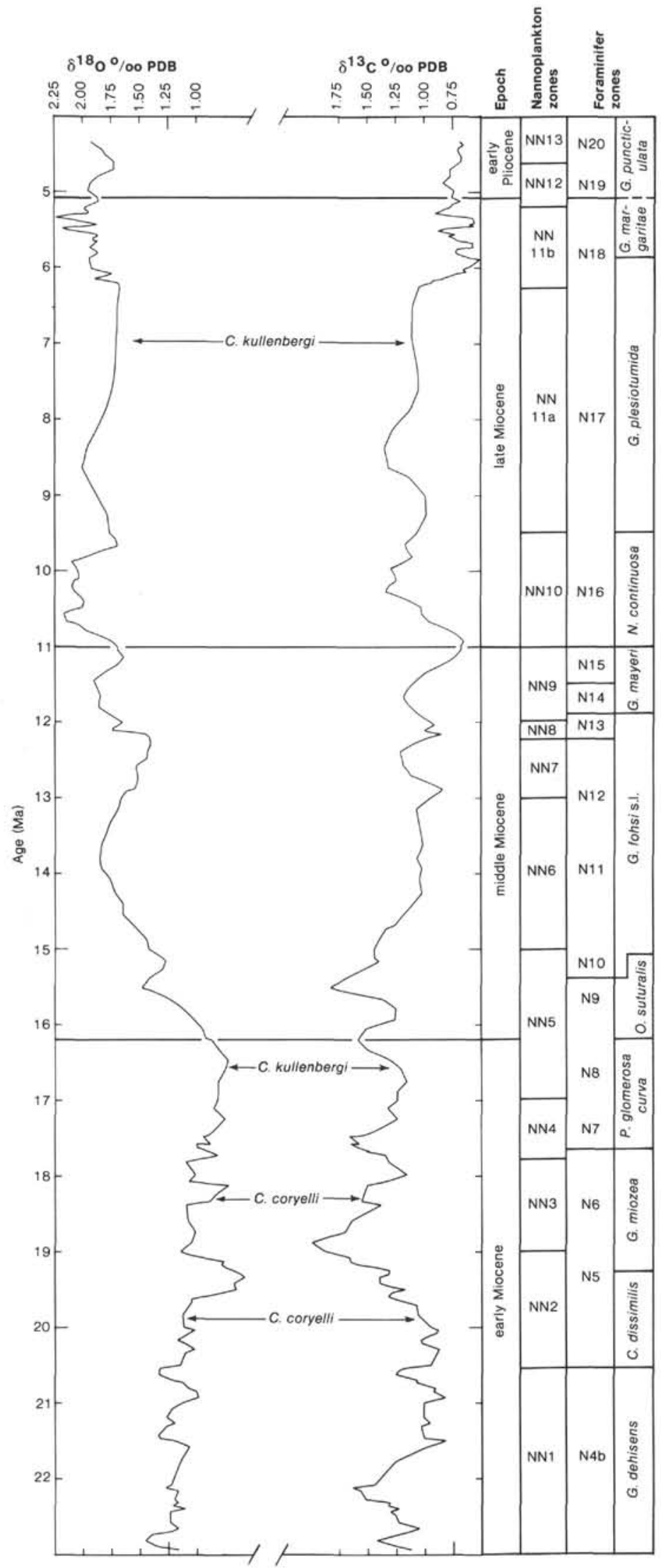

Figure 4. Smoothed benthic $\delta^{18} \mathrm{O}$ and $\delta^{13} \mathrm{C}$ data (three-point running averages) for Holes 588, 588A, and 588C and biostratigraphic zonations for Site 588, plotted against age. 


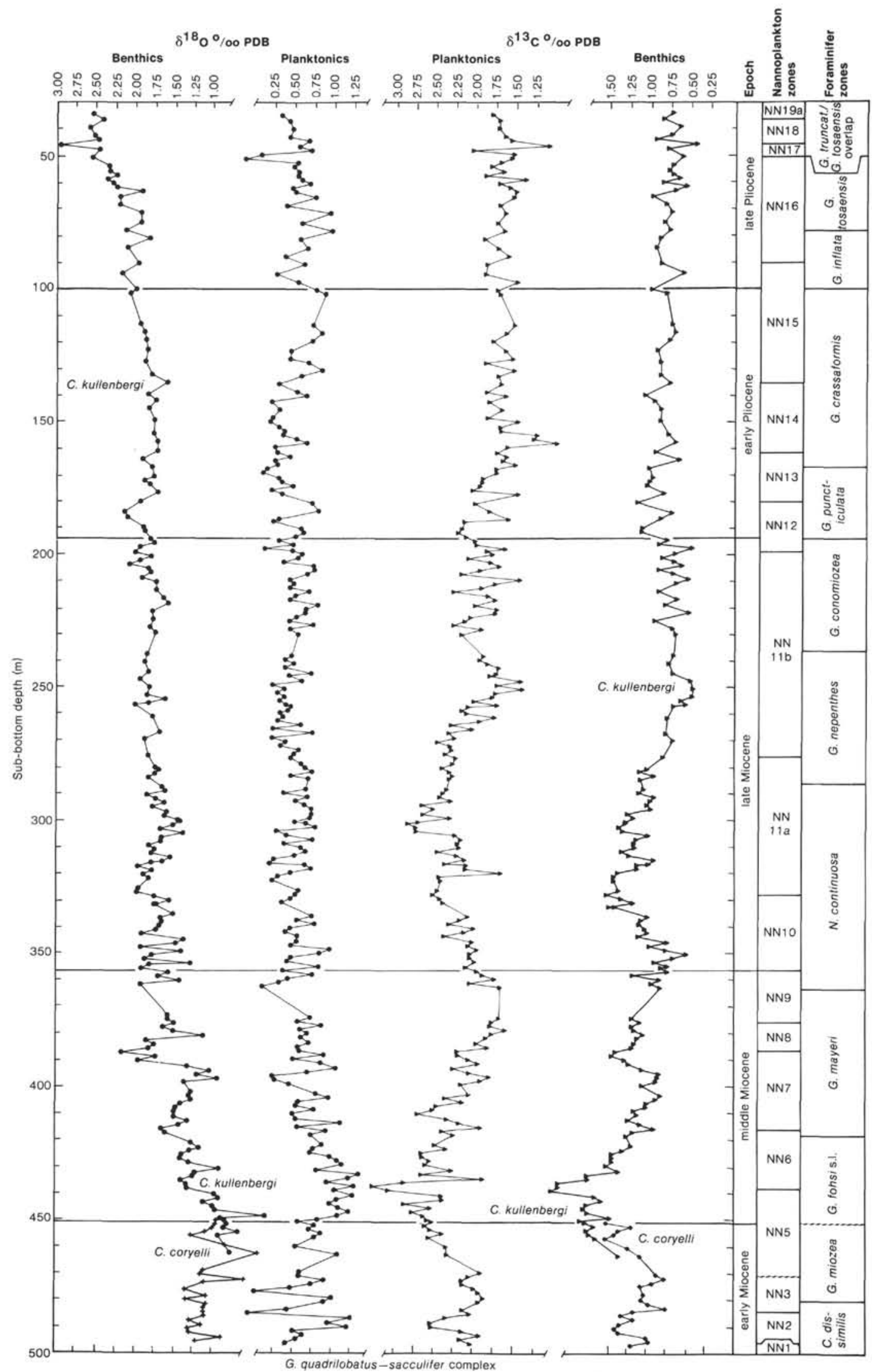

Figure 5. Benthic and planktonic $\delta^{18} \mathrm{O}$ and $\delta^{13} \mathrm{C}$ for Holes $590 \mathrm{~A}$ and $590 \mathrm{~B}$ plotted against depth in Site 590 and biostratigraphic zonations for calcareous nannoplankton (Lohman, this volume) and planktonic foraminifers (Jenkins and Srinivasan, this volume). 
ty. Relatively high $\delta^{13} \mathrm{C}$ values mark the earliest Miocene between about 23 and $22 \mathrm{Ma}$, followed by lower values between 22 and $19.5 \mathrm{Ma}$. This, in turn, was followed by the most conspicuous feature of the Neogene benthic carbon isotope record: a period of increased $\delta^{13} \mathrm{C}$ values from the late early Miocene to the early middle Miocene, between 19.5 and $15 \mathrm{Ma}$. The increase leading to these high $\delta^{13} \mathrm{C}$ values consisted of a shift of about $1 \%$ that occurred between $\sim 19.8$ and $18.8 \mathrm{Ma}$. Although overall values were high during this interval, distinct fluctuations occurred, including minima centered at 18.0, 17.0 , and $15.8 \mathrm{Ma}$. The return to lower values is also distinctive, consisting of a $-1 \%$ shift between 15.4 and 14.2 in the early middle Miocene. Following this major mid-Neogene episode, there were no such major fluctuations in $\delta^{13} \mathrm{C}$ during the remainder of the middle and late Miocene except for a negative peak centered at about 11.2 Ma near the middle/late Miocene boundary. Following this, the most distinctive change in the Neogene benthic carbon isotope record occurred during the late Miocene at about 6.2 Ma, representing a marked shift in $\delta^{13} \mathrm{C}$ values of about $-0.7 \%$. This represents the wellknown latest Miocene carbon isotope shift (see Vincent et al., 1980, for review). Generally lower values mark the remainder of the latest Miocene and the early Pliocene, although there was a trend toward slightly higher values during the early Pliocene (5.2 to $4 \mathrm{Ma}$ ). The record from Site 588 suggests that the most important events in $\delta^{13} \mathrm{C}$ occurred at $\sim 22$ to $21.6 \mathrm{Ma} ; 19.8$ to 19 $\mathrm{Ma} ; 15.4$ to $14.2 \mathrm{Ma}$; and $6.2 \mathrm{Ma}$.

Site $\mathbf{5 9 0}$

\section{Benthic Foraminiferal Oxygen Isotopes}

Sedimentation at Site 590 was continuous except for an unconformity centered in the latest early Miocene between about 18 and $16.5 \mathrm{Ma}$. The early Miocene exhibits relatively low $\delta^{18} \mathrm{O}$ values, with the lowest values for the entire Neogene probably dated between about 19 and $18 \mathrm{Ma}$. From the latest early Miocene (about 16.5 Ma) until about $13 \mathrm{Ma}, \delta^{18} \mathrm{O}$ values increased irregularly by about $1 \%$.

During the remainder of the Miocene and early Pliocene, average values remained unchanged, although important oscillations occurred. These include an episode of lower values (warmer temperatures) centered at about 12.5 Ma followed rapidly by a brief interval of higher values centered at 12.2 Ma. An interval of high values is also centered at about $4.8 \mathrm{Ma}$ in the earliest Pliocene.

Important positive shifts $(\sim 0.75 \%)$ occurred during the Pliocene between about $3.5 \mathrm{Ma}$ and $2.2 \mathrm{Ma}$; these changes are discussed in detail by Elmstrom and Kennett (this volume).

\section{Planktonic Foraminiferal Oxygen Isotopes}

The planktonic oxygen isotope record (Figs. 6 and 7) generally exhibits higher variability than the benthic record, especially during the early Miocene, latest Miocene, and Pliocene. The high variability in the early Miocene, between 20 and $18 \mathrm{Ma}$, of up to $1.3 \%$, is considered to have resulted from recrystallization of planktonic foraminiferal tests.
The early middle Miocene exhibits distinctly lower values (warmer isotopic temperatures) between 16 and 14.5 $\mathrm{Ma}$. This was followed by the well-known $\delta^{18} \mathrm{O}$ increase ( of about $1 \% 0$ ), which continued in the $\delta^{18} \mathrm{O}$ planktonic record at this site until about $12.4 \mathrm{Ma}$. Following this, no apparent long-term trends occurred during the latest middle and late Miocene in planktonic $\delta^{18} \mathrm{O}$ until $6 \mathrm{Ma}$. At that time, a distinct positive shift occurred of about $0.5 \% 0$ (cooler temperatures). Average latest Miocene to Pliocene values are almost $0.5 \%$ higher than during the earlier part of the late Miocene. After $6 \mathrm{Ma}$, several distinct planktonic $\delta^{18} \mathrm{O}$ oscillations occurred, including an increase between about $4.6 \mathrm{Ma}$ and $3.7 \mathrm{Ma}(0.5 \%)$ and another increase beginning at $3 \mathrm{Ma}$ and continuing to the Pleistocene (at least to $1.8 \mathrm{Ma}$ ). Intervals marked by lower values occurred between 5.4 and 5.2 , between 4.8 and 4.6, and between 3.7 and $3 \mathrm{Ma}$. Detailed descriptions of these changes have been made by Elmstrom and Kennett (this volume).

\section{Benthic and Planktonic Foraminiferal Carbon Isotopes}

Distinct parallelism occurs between benthic and planktonic carbon isotope records (Figs. 6 and 7), including many of the short-term oscillations, although the amplitude of change often differs. Because of their similarity of change, the records are described as one. The earliest Miocene sequence (20.8 to $18 \mathrm{Ma}$ ), preceding the unconformity, exhibits relatively low $\delta^{13} \mathrm{C}$ values. A major increase in $\delta^{13} \mathrm{C}(\sim 1.2 \%)$ occurred during the latest early Miocene to early middle Miocene, with highest values centered at about $15 \mathrm{Ma}$. This is the most distinct carbon isotope episode of the Neogene. Following this broad early middle Miocene peak, there was a somewhat irregular decrease in $\delta^{13} \mathrm{C}$ values, which reached particularly low values between about 11.5 and $10.5 \mathrm{Ma}$, close to the middle/late Miocene boundary. Values again increased toward a maximum in the middle late Miocene between about 9.5 and $8 \mathrm{Ma}$. In the latest Miocene at 6.2, a distinct, rapid, negative carbon isotope shift occurred that is synchronous with the Chron 6 carbon isotope shift. The carbon isotope change in the planktonic record $(\sim 0.9 \%)$ is almost double that exhibited in the benthic record $(\sim 0.4 \%)$. Relatively low $\delta^{13} \mathrm{C}$ values mark the remainder of the late Neogene sequence. Following the Miocene/Pliocene boundary, at 5.2 Ma, a temporary increase in $\delta^{13} \mathrm{C}$ occurred. This, in turn, was followed by a return to generally lower values typical of the middle and late Pliocene. Details of these changes are described in Elmstrom and Kennett (this volume).

\section{Site 591}

\section{Benthic Foraminiferal Oxygen Isotopes}

The stable isotope record at Site 591 extends from the late early Miocene (17 Ma) to the middle Pliocene (4 Ma) (Figs. 8-10). The benthic $\delta^{18} \mathrm{O}$ record exhibits the lowest values (warmest isotopic temperatures) at about $17 \mathrm{Ma}$. From $17 \mathrm{Ma}$ (latest early Miocene) to about 14.5 $\mathrm{Ma}$, an irregular increase in $\delta^{18} \mathrm{O}$ values of about $1.25 \%$ occurred, synchronous with the early middle Miocene shift observed in other sites. The time of maximum change occurred between $\sim 16$ and $15.2 \mathrm{Ma}$. Although 


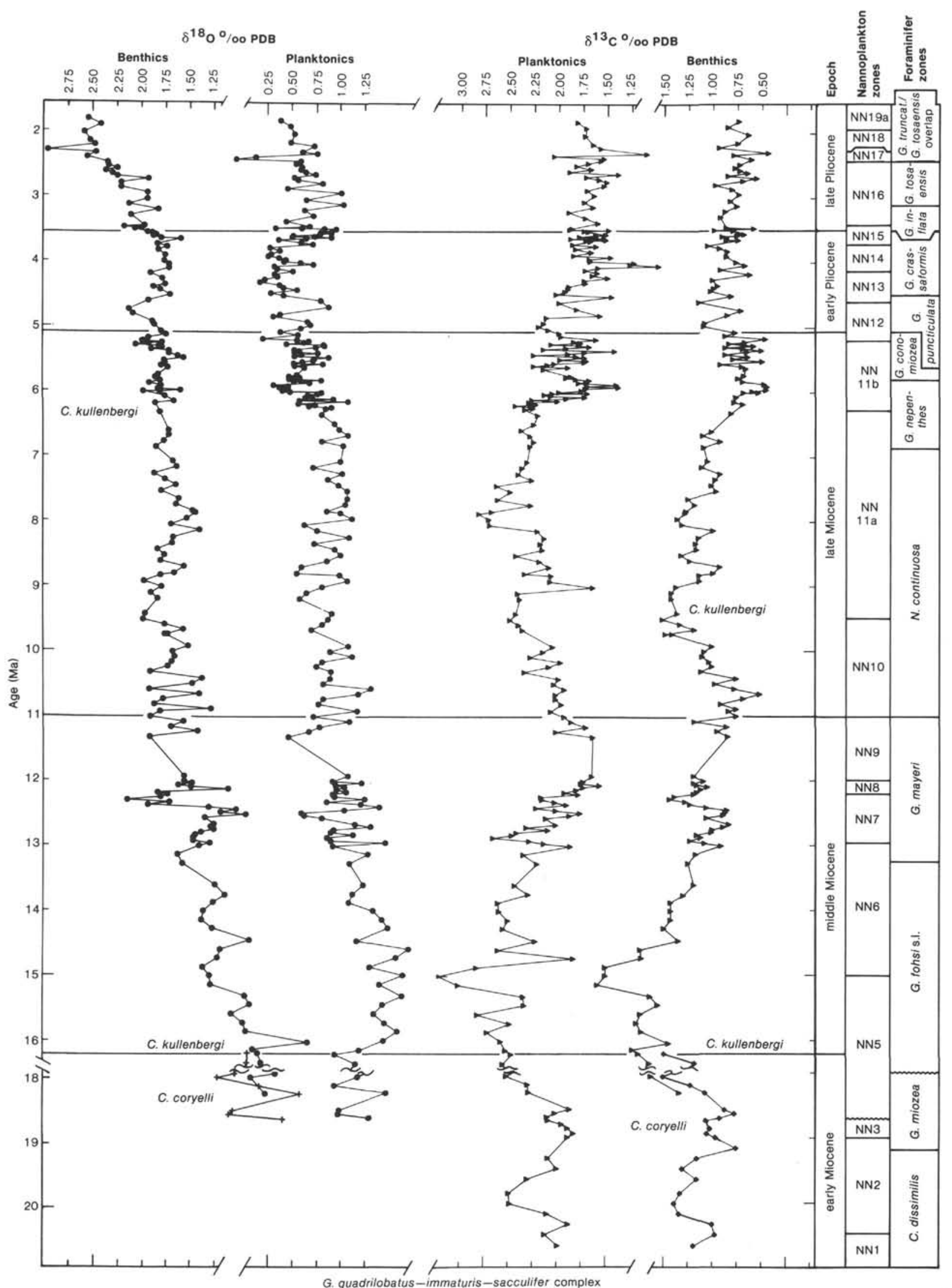

Figure 6. Benthic and planktonic $\delta^{18} \mathrm{O}$ and $\delta^{13} \mathrm{C}$ for Holes $590 \mathrm{~A}$ and $590 \mathrm{~B}$ plotted against age in Site 590 and biostratigraphic zonation for calcareous nannoplankton (Lohman, this volume) and planktonic foraminifers (Jenkins and Srinivasan, this volume). Note unconformity between 16.5 and $18 \mathrm{Ma}$. 


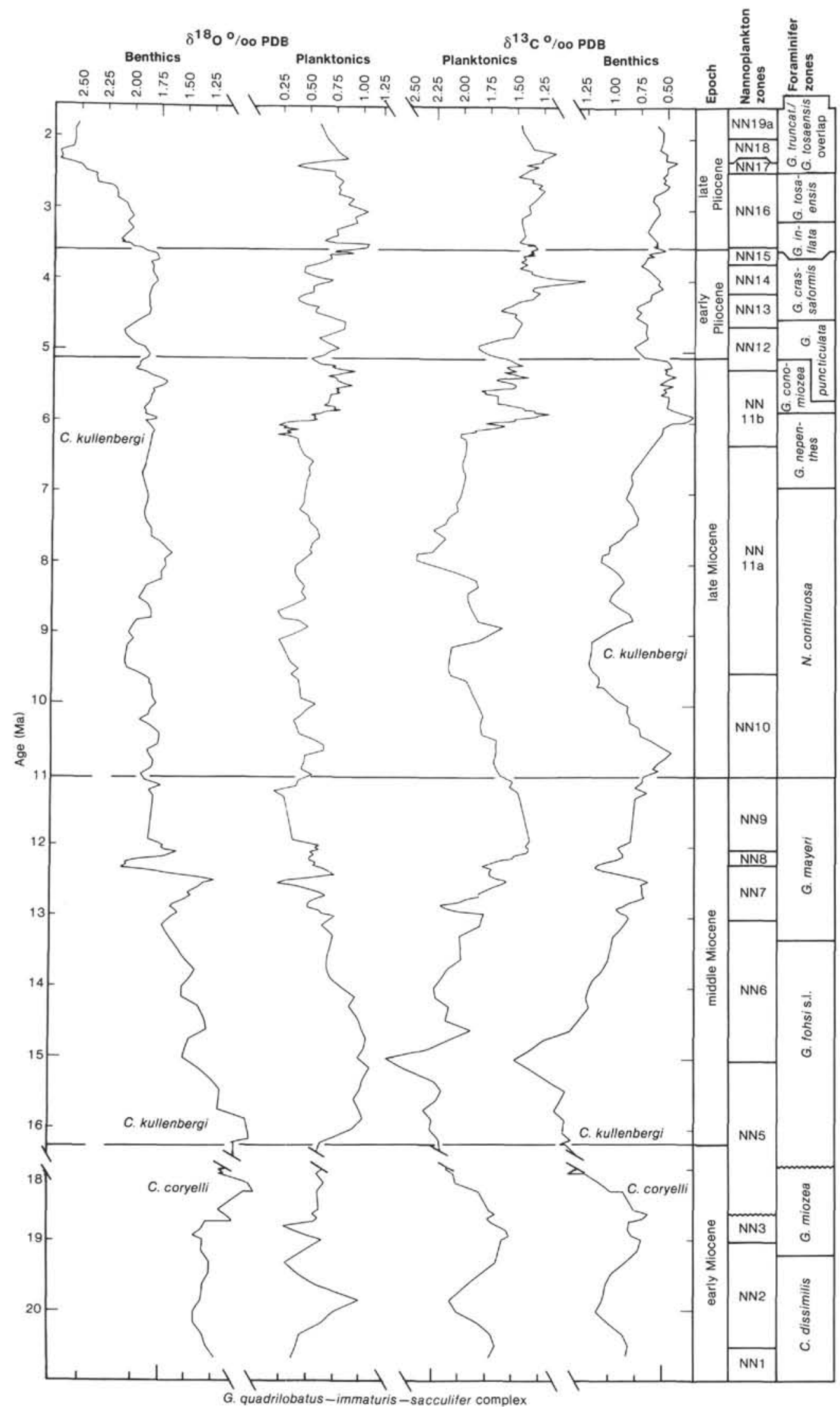

Figure 7. Smoothed benthic and planktonic $\delta^{18} \mathrm{O}$ and $\delta^{13} \mathrm{C}$ data (three-point running averages) for Holes 590A and $590 \mathrm{~B}$ and biostratigraphic zonations for Site 590 , plotted against age. 


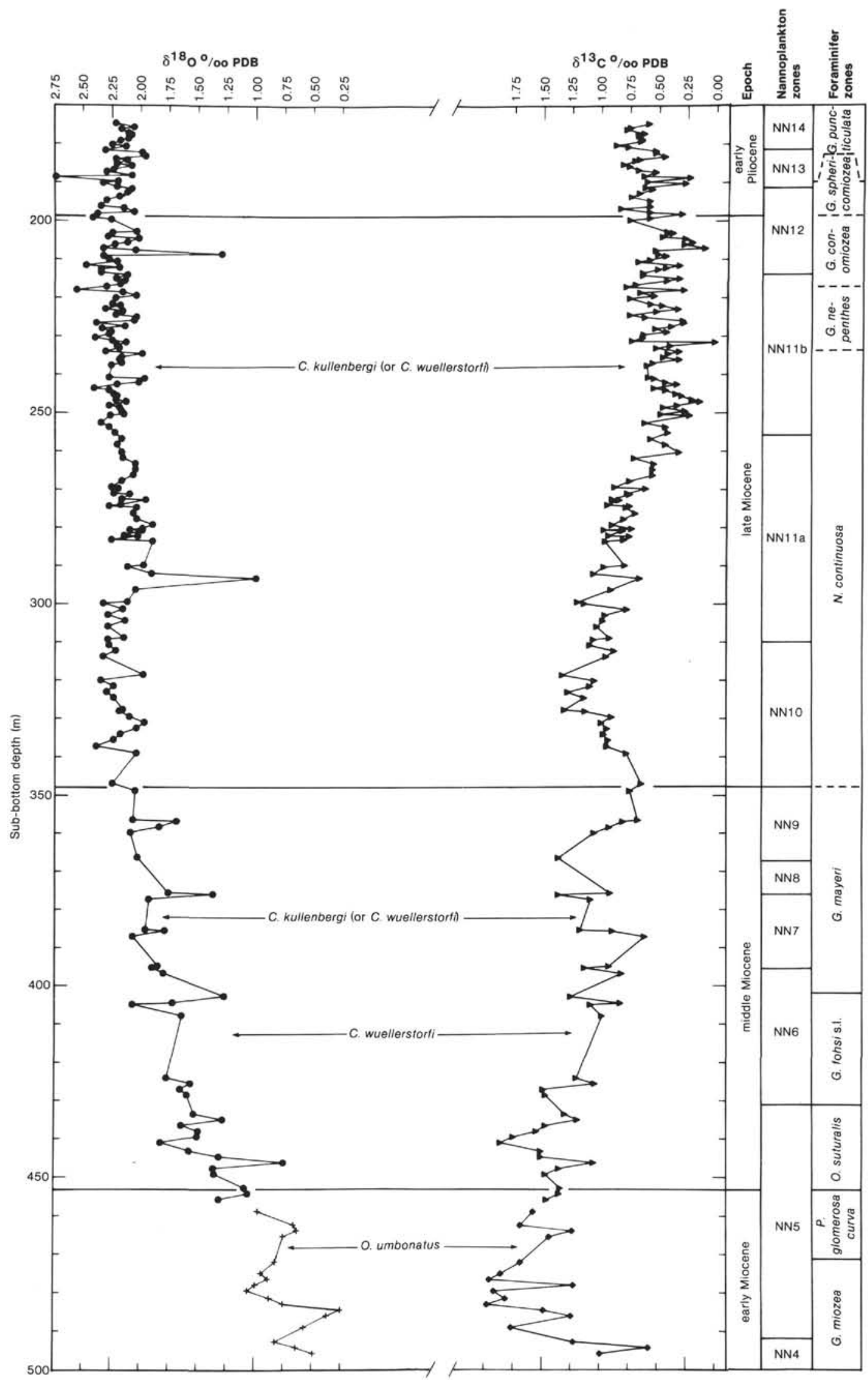

Figure 8. Benthic $\delta^{18} \mathrm{O}$ and $\delta^{13} \mathrm{C}$ for Holes 591 and 591B plotted against depth in Site 591 and biostratigraphic zonation for calcareous nannoplankton (Lohman, this volume) and planktonic foraminifers (Introduction, this volume). Stable isotope data for Oridorsalis umbonatus have been adjusted to that of Cibicidoides by adding $+1.06 \%$ for $\delta^{13} \mathrm{C}$ and subtracting 0.72 for $\delta^{18} \mathrm{O}$ (see text for discussion). 


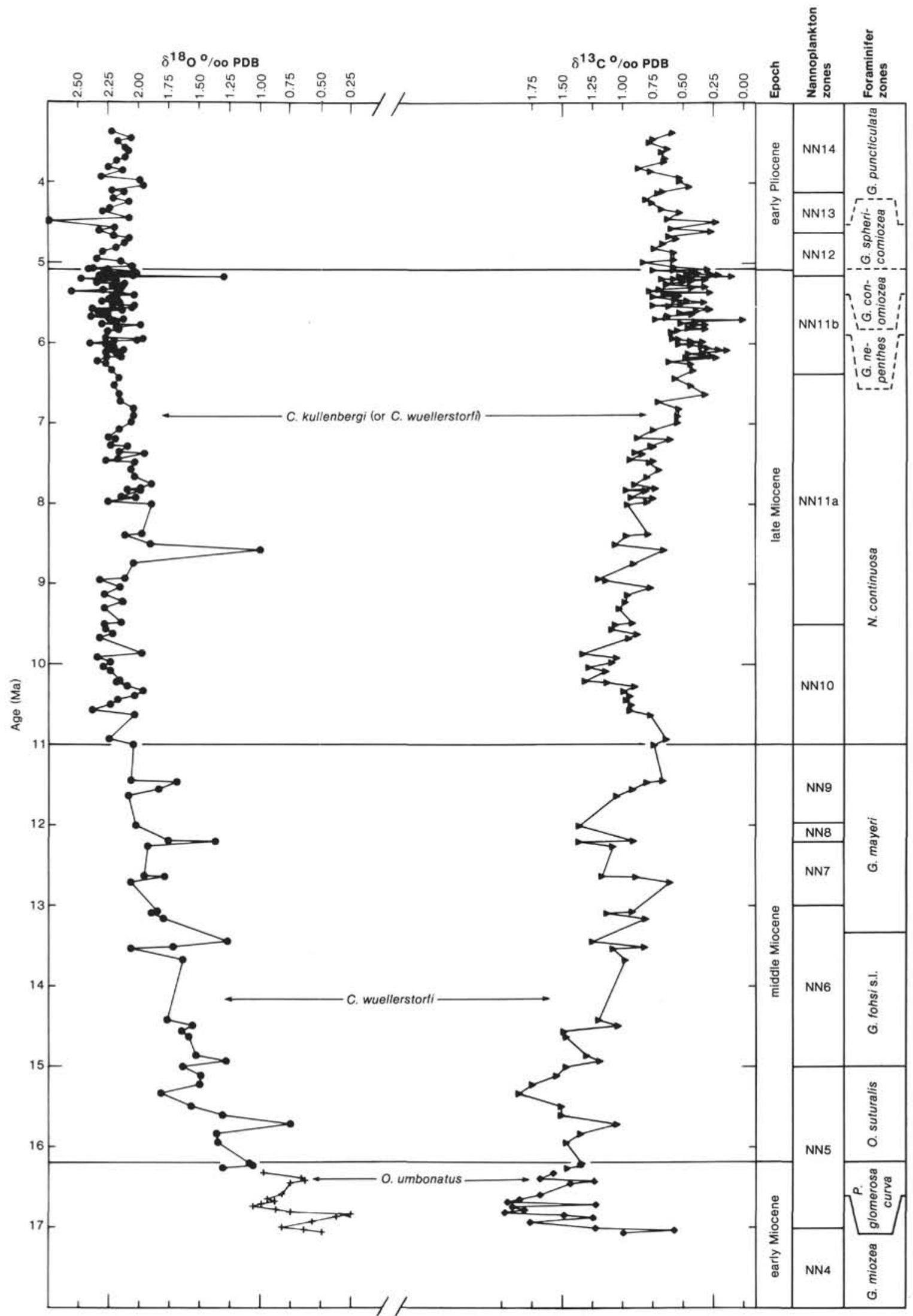

Figure 9. Benthic $\delta^{18} \mathrm{O}$ and $\delta^{13} \mathrm{C}$ for Holes 591 and 591B plotted against age in Site 591 and biostratigraphic zonation for calcareous nannoplankton (Lohman, this volume) and planktonic foraminifers (Introduction, this volume). Stable isotope data for Oridorsalis umbonatus have been adjusted to that of Cibicidoides by adding $+1.06 \%$ for $\delta^{13} \mathrm{C}$ and subtracting 0.72 for $\delta^{18} \mathrm{O}$ (see text for discussion). 


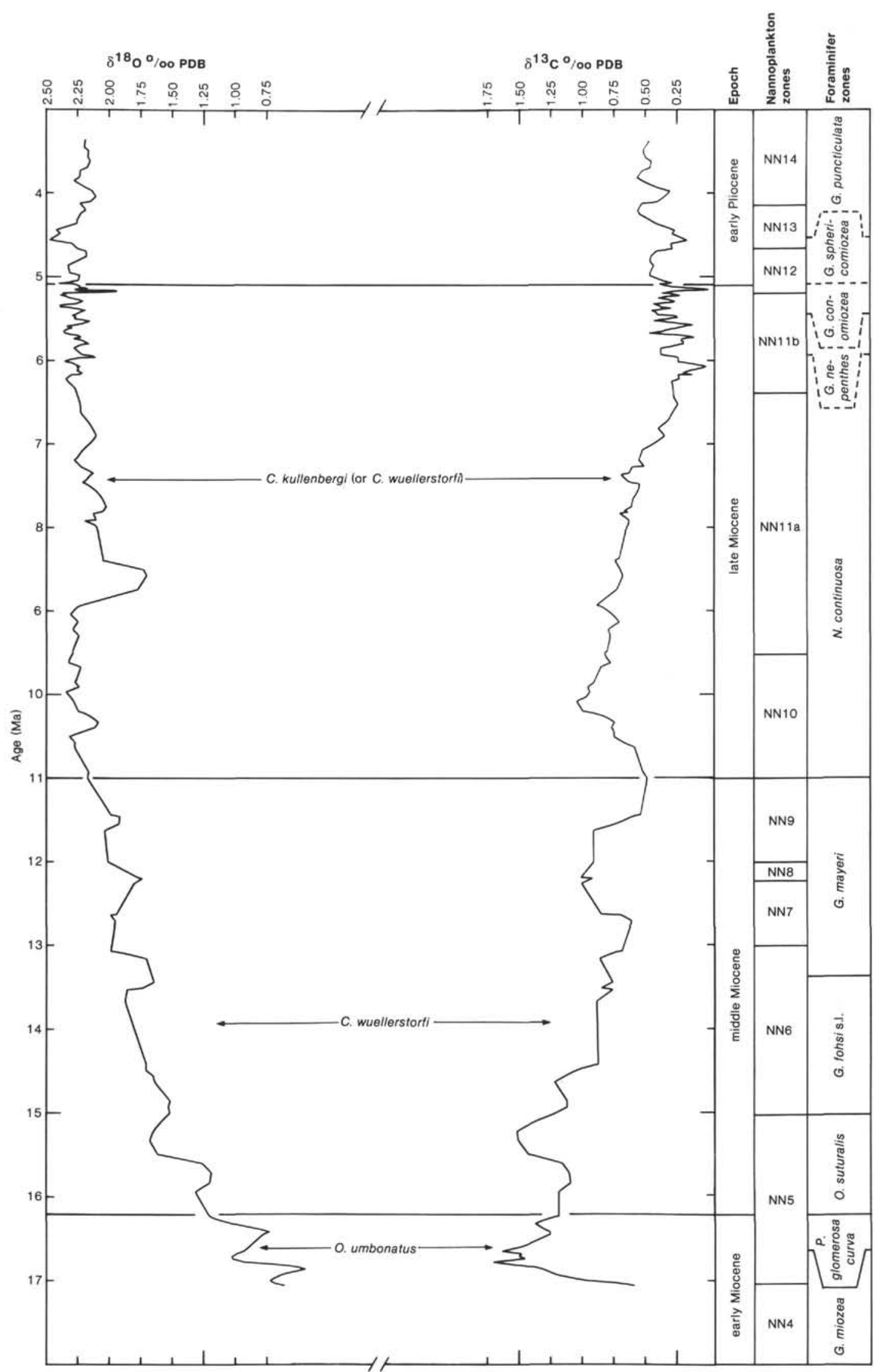

Figure 10. Smoothed benthic $\delta^{18} \mathrm{O}$ and $\delta^{13} \mathrm{C}$ data (three-point running averages) for Holes 591 and 591B and biostratigraphic zonations for Site 591, plotted against age. 
stratigraphic resolution during the middle Miocene at this site is not high, some trends seem to be evident. From 14.5 to $11.5 \mathrm{Ma}$, the $\delta^{18} \mathrm{O}$ values remained much the same or perhaps slightly increased, reaching a maximum close to the middle/late Miocene boundary at $\sim 11.5 \mathrm{Ma}$. During the late Miocene and the Pliocene, there was relatively little change in $\delta^{18} \mathrm{O}$ in this section.

\section{Benthic Foraminiferal Carbon Isotopes}

The benthic carbon isotope record at Site 591 (Figs. $8-10)$ is similar to that of Site 588 and exhibits considerable variability. As at Site 588 , the most conspicuous feature of the record is the interval of increased $\delta^{13} \mathrm{C}$ values during the late early to early middle Miocene (base of sequence at $17 \mathrm{Ma}$ to $14.5 \mathrm{Ma}$ ). During the remainder of the Miocene the $\delta^{13} \mathrm{C}$ values generally decreased, reaching a minimum between about 11.6 and $10.6 \mathrm{Ma}$, associated with the middle/late Miocene boundary. This was followed by a $\delta^{13} \mathrm{C}$ maximum at $10.0 \mathrm{Ma}$ and then gradually decreasing values in the late Miocene, culminating in a distinct shift toward low $\delta^{13} \mathrm{C}$ values from about 7.5 to $6 \mathrm{Ma}$. However, unlike the record at the other two sites, this latest Miocene carbon isotope shift was more gradual, rather than sharply defined at 6.2 Ma. A gradual depletion in ${ }^{13} \mathrm{C}$ of $0.4 \%$ occurred between 7.5 and 6.2 , with an additional shift of $0.5 \%$ centered at 6.2 Ma. During the early Pliocene between 5 and $4 \mathrm{Ma}$, average $\delta^{13} \mathrm{C}$ values were about $0.25 \%$ higher than latest Miocene values.

\section{DISCUSSION}

\section{Oxygen Isotopes}

The oxygen isotope composition of calcite is controlled by both the oxygen isotope composition of ambient seawater and its temperature (Epstein et al., 1953). The isotopic composition of the oceans is strongly affected by changes in continental ice volume because ${ }^{16} \mathrm{O}$ is preferentially stored in such ice. An increase in continental ice volume causes an increase in $\delta^{18} \mathrm{O}$ values of the ocean. A record of ice volume is provided by benthic foraminiferal oxygen isotope changes during intervals when the temperatures of ocean bottom waters remained constant. Planktonic foraminiferal $\delta^{18} \mathrm{O}$ is controlled by local and global changes in the isotopic composition of the oceans and temperature of surface waters. It is difficult to differentiate the effects of temperature from those due to ice volume. The detailed relations provided here between benthic and planktonic $\delta^{18} \mathrm{O}$ changes at different latitudes may help differentiate between changes that resulted from ice volume and those that resulted from temperature.

This chapter has no statistically based correlations between the isotope stratigraphies of the individual sites. Nevertheless, visual comparison of the curves shows that many events are easily recognizable in the three sequences. Intersite correlation of these isotopic events also reveals that the assigned ages of individual events, based upon correlations using the nannoplankton biostratigraphy, are not identical in each of the sequences. Individual peaks are often offset by 0.1 to $0.3 \mathrm{~m}$.y. It is clear that intersite correlation could be enhanced by the combined use of $\delta^{13} \mathrm{C}$ and $\delta^{18} \mathrm{O}$ stratigraphy. More detailed composite isotopic curves will be established in the future by applying quantitative techniques of signal correlation to these and other existing records. In the meantime, visual comparisons of the isotope stratigraphy for the three sites are adequate for interpretation of paleoceanographic history. In the following sections, a synthesis is provided of this history.

\section{Early Miocene}

The earliest Miocene (oldest than 19.5 Ma) was marked by relatively high benthic $\delta^{18} \mathrm{O}$ values, although the values were lower than those of the late Miocene. This indicates warmer intermediate water and less continental ice during the earliest Miocene than during the late Miocene. A slow, general warming of intermediate water occurred between 23 and $19.5 \mathrm{Ma}$, leading to the lowest $\delta^{18} \mathrm{O}$ values for the entire Neogene between about 19.5 and 16.5 Ma (late early Miocene; late NN2 to middle NN5). This interval represents the optimum of Neogene warmth. Haq (1980) identified a particularly warm interval between 17 and $16 \mathrm{Ma}$ based on mid- to high-latitude Atlantic calcareous nannoplankton biogeography. A minor, cool episode occurred within this warm period between 19 and $18 \mathrm{Ma}$.

\section{Middle Miocene}

The late early Miocene climatic optimum at $16.5 \mathrm{Ma}$ immediately preceded the major middle Miocene episode of increasing $\delta^{18} \mathrm{O}$ values, which I interpret to represent major, permanent accumulation of the East Antarctic ice sheet and cooling of bottom waters (Shackleton and Kennett, 1975b; Savin et al., 1975). Thus, sea-surface temperatures at high latitude were relatively warm immediately preceding the buildup of the Antarctic ice sheet, a necessary prerequisite according to Mercer and Suter (1982).

The early middle Miocene $\delta^{18} \mathrm{O}$ increase began about 16.5 to $16 \mathrm{Ma}$, and continued until about 13.5 to 13.2 $\mathrm{Ma}$; the total duration of this event was about 3 m.y. Barron et al. (in press) previously assigned an age of 15.0 to $13.5 \mathrm{Ma}$ to this shift, which encompasses Zones $\mathrm{N} 9$ to lower N12. The maximum enrichment in ${ }^{18} \mathrm{O}$ during this event ranged between 1.25 and $1.50 \%$. This ${ }^{18} \mathrm{O}$ enrichment event has been globally recognized in marine sedimentary sections by Savin et al. (1975); Shackleton and Kennett (1975b), Keigwin (1979), Margolis et al. (1975), Loutit (1981), Loutit, Kennett, et al. (1983); Vincent and Berger (1985); Vincent et al. (in press); Savin et al. (1981), Woodruff et al. (1981), Savin et al. (in press), and many other workers. Haq (1980) identified a cooling trend in mid- to high-latitude Atlantic calcareous nannoplankton assemblages at $15 \mathrm{Ma}$ that he correlated with this isotopic event.

The middle Miocene event has generally been accepted as representing permanent, major buildup of the East Antarctic ice sheet (Savin et al., 1975; Shackleton and Kennett, 1975b) and an associated decrease in bottomwater temperatures related to enhance polar glaciation (Savin et al., 1975). This interpretation was challenged 
by Matthews and Poore (1980), who suggested that all of the isotopic change was due to the decreasing temperature of intermediate and bottom waters. They attributed none of the isotopic shift to ice accumulation, since they believed that most of the Antarctic ice sheet had formed by at least the earliest Oligocene, and used as supporting evidence the major sea-level fall during the middle Oligocene (Vail and Hardenbol, 1979).

Tropical planktonic $\delta^{18} \mathrm{O}$ values decrease, show no change, or exhibit an increase that is smaller in magnitude than the shift observed in high-latitude sequences. Savin et al. (1981, in press), Loutit, Kennett, et al. (1983) and others interpreted these observations as reflecting a warming of tropical sea-surface temperatures. Warming of tropical surface waters during the middle Miocene may have resulted from the progressive thermal isolation of Antarctica and the contraction of the tropical-warm subtropical gyres toward lower latitudes, as the polar and subpolar waters expanded toward the equator. A major question remains, however, as to how much of the $\delta^{18} \mathrm{O}$ shift during the early middle Miocene was due to increased ice volume and how much to decreased temperature.

Comparison of planktonic and benthic $\delta^{18} \mathrm{O}$ records at Site 590 (Figs. 6 and 7) may assist in separating these effects, although interpretations are not unequivocal. Site 590 is currently located at $31^{\circ} \mathrm{S}$, in proximity to the Subtropical Divergence that separates the warm-subtropical and temperate water masses. During the early middle Miocene, this site was located in the present temperate latitudes of about $34^{\circ} \mathrm{S}$ (Sclater et al., in press). At Site 590 , the shift toward higher benthic $\delta^{18} \mathrm{O}$ values began at $16 \mathrm{Ma}$ (Figs. 6 and 7) and continued until $13.2 \mathrm{Ma}$, with a total shift of about $1.25 \%$. In contrast, the planktonic $\delta^{18} \mathrm{O}$ values actually decreased at $16 \mathrm{Ma}$ by about $0.25 \% 0$ and remained low until $14.6 \mathrm{Ma}$. This indicates a distinct warming of surface waters during the early stage of glaciation. The data of Vincent et al. (in press) from the tropical Indian Ocean also exhibit surface-water warming during the first half of the middle Miocene benthic $\delta^{18} \mathrm{O}$ increase. At Site 590 , planktonic $\delta^{18} \mathrm{O}$ values increased irregularly by about $0.65 \%$ between 14.6 and 13.2 Ma (Figs. 6 and 7). The magnitude of the planktonic $\delta^{18} \mathrm{O}$ change was only half that exhibited by benthic $\delta^{18} \mathrm{O}$. Based upon these observations, we suggest that the early stage of the middle Miocene $\delta^{18} \mathrm{O}$ shift (between 16 and 14.6 Ma) resulted largely from high-latitude cooling, which was followed by a phase in which the benthic isotope record largely reflected ice growth between 14.6 and 13.2 Ma (or 13.6 Ma, as indicated in Site 588). The smaller magnitude of the increase in planktonic $\delta^{18} \mathrm{O}$ than benthic $\delta^{18} \mathrm{O}$ suggests that surface waters warmed at these sites near the northern edge of the temperate zone during the middle Miocene. Savin et al. (1975), Savin et al. (in press), and Loutit, Kennett, et al. (1983) suggested previously that sea-surface temperatures in the tropical Pacific warmed during the middle Miocene. Assuming an adjustment in ice volume of $0.5 \%$ and no major changes in the regional variation of the ${ }^{18} \mathrm{O} /{ }^{16} \mathrm{O}$ ratio of surface waters, then tropical Pacific sur- face waters typically warmed by 2 to $5^{\circ} \mathrm{C}$ during the middle Miocene (Savin et al., in press).

The middle Miocene benthic $\delta^{18} \mathrm{O}$ shift exhibits numerous oscillations of up to $0.5 \%$, although these are smaller than the $1 \%$ changes reported at Site 289 in the western tropical Pacific (Woodruff et al., 1981), where sampling density was higher. A brief but well-defined episode of more positive $\delta^{18} \mathrm{O}$ values is centered at 15 (Site 590) or $15.5 \mathrm{Ma}$ (Sites 588 and 591), within the main $\delta^{18} \mathrm{O}$ shift, and may be equivalent to the same episode dated at 15 Ma by Savin et al. (1981).

The isotopic data show two more episodes of especially cool surface and deep water close to the middle/ late Miocene boundary. The earliest of these, between 12.5 and $11.5 \mathrm{Ma}$, seems to be equivalent to that dated by Savin et al. (1981) between 13.5 and $12.5 \mathrm{Ma}$. This event apparently correlates with the early part of paleomagnetic Chron $11(\sim 11.7 \mathrm{Ma})$ according to Burckle et al. (1982). Following a period of warming, a second decline of isotopic temperatures (not well defined in Site 590) occurred between 11 and 9 Ma (earliest late Miocene), but this event was dated by Savin et al. (1981) as occurring between 11.8 and $10.5 \mathrm{Ma}$. This event was correlated with the early part of paleomagnetic Chron $10(11.4-11 \mathrm{Ma})$ by Burckle et al. (1982). Some of the highest $\delta^{18} \mathrm{O}$ values (coldest isotopic temperatures) for the entire Miocene occur within this interval.

\section{Late Miocene}

The late Miocene was marked by large, but variable benthic $\delta^{18} \mathrm{O}$ values reflecting a period of prolonged cool climates. Intermediate waters were coldest near the beginning (11 to $9 \mathrm{Ma}$ ) and the end of the late Miocene ( $\sim 6.5$ to $4.5 \mathrm{Ma})$.

During much of the middle late Miocene, between about 9 and $6.5 \mathrm{Ma}$, average $\delta^{18} \mathrm{O}$ values were slightly lower, indicating a general period of relative climatic warmth (this is not observed at Site 590). Haq (1980) also noted warm climate conditions during the middle late Miocene, between 9 and $7 \mathrm{Ma}$, based upon Atlantic calcareous nannoplankton biogeography.

Further cooling occurred during the latest Miocene, beginning at about $6.2 \mathrm{Ma}$ (shown as $5.5 \mathrm{Ma}$ in Site 590 ), and continued until about 5 to $4.5 \mathrm{Ma}$. Similar high $\delta^{18} \mathrm{O}$ values were reported by Shackleton and Kennett (1975a) from Site 284, and interpreted to represent a major expansion of the Antarctic ice sheet. This terminal Miocene event was marked by widespread cooling. Moderate to severe cooling of the ocean surface in middle to high latitudes is well documented over wide areas during the latest Miocene (Ingle, 1967, 1973; Keller, 1979; Kennett, 1967; Kennett and Vella, 1975; Loutit and Kennett, 1979; Bandy et al., 1971; Cita and Ryan, 1979; Poore, 1981; Haq, 1980). In Argentina, Patagonian glaciers extended beyond the Andean Mountain front, apparently for the first time, between about 7 and 5.2 Ma (Mercer and Sutter, 1982). In Sites 588 (Fig. 3) and 591 (Fig. 9), a number of brief intervals of high $\delta^{18} \mathrm{O}$ values between 5.4 and $4.9 \mathrm{Ma}$ are interpreted to represent further increases in Antarctic ice volume (Hodell, 
Elmstrom, and Kennett, unpublished data). The terminal Miocene event was also marked by marine regression (Kennett, 1967; Adams et al., 1977), growth of the West Antarctic ice sheet (Ciesielski et al., 1982), intensification of oceanic circulation (Brewster, 1980; Savin et al., in press), high sediment accumulation rates (Davies et al., 1977), and the Messinian Salinity Crisis (Hsü et al., 1973; Cita, 1976). The late Miocene was also the time of the distinct latest Miocene carbon isotope shift (Keigwin, 1979).

During the late Miocene until $6.2 \mathrm{Ma}$, planktonic $\delta^{18} \mathrm{O}$ values exhibited large, rapid oscillations about an unchanging average (Figs. 6 and 7). At 6.2 Ma, a marked increase in $\delta^{18} \mathrm{O}$ of about $0.5 \% 0$ coincided exactly with the late Miocene Chron 6 carbon shift. This represents significant and rapid cooling of surface waters. In Site 588 , the carbon shift also coincided with a shift toward higher benthic $\delta^{18} \mathrm{O}$ values.

\section{Pliocene}

During the early Pliocene, benthic $\delta^{18} \mathrm{O}$ values oscillated about an average similar to that of the latest Miocene. At about 3.4 Ma, a 0.4\%o increase (Elmstrom and Kennett, this volume) is documented in the benthic $\delta^{18} \mathrm{O}$ record of Site 590 (Figs. 6 and 7). An oxygen isotope shift similar to this has been reported from the equatorial Pacific (Shackleton and Opdyke, 1977; Keigwin, 1979; Prell, 1984), the South Atlantic (Weissert et al., 1984), the North Atlantic (Shackleton and Cita, 1979), and the Mediterranean (Keigwin and Thunell, 1980). This shift almost certainly documents a cooling of intermediate waters (Prell, 1984), but possibly also some additional growth of Antarctic ice (Weissert et al., 1984). Increased glaciation of Antarctica at about $3.5 \mathrm{Ma}$ created a northward shift in the deposition of circum-Antarctic glacial marine sediments (Ciesielski and Weaver, 1974). A glacial increase at about $3.5 \mathrm{Ma}$ is also consistent with the observation by Keany (1978) of cooling of the Southern Ocean at 3.6 Ma, with cooling in temperate areas (Kennett and Vella, 1975; Kennett et al., 1979), and with increased Patagonian glaciation (Mercer, 1976). Significant sediment ice-rafting in the North Atlantic did not seem to occur until $2.5 \mathrm{Ma}$. Evidence of ice-rafted material prior to $2.4 \mathrm{Ma}$ is negligible and may be due to glaciation unrelated to major Northern Hemisphere ice sheets (Backman, 1979; Shackleton et al., 1984).

The planktonic $\delta^{18} \mathrm{O}$ record during the Pliocene is distinctly different from the benthic $\delta^{18} \mathrm{O}$ record. First, the planktonic isotopic record is more variable, reflecting rapidly changing surface-water conditions. Secondly, planktonic and benthic records are not parallel. Higher planktonic $\delta^{18} \mathrm{O}$ values, reflecting cooler surface waters, occurred between 4.6 and $3.6 \mathrm{Ma}$. In contrast, benthic $\delta^{18} \mathrm{O}$ values show no such trend during this interval. The transition from warm early Pliocene to cooler middle Pliocene intermediate waters is not reflected in the planktonic $\delta^{18} \mathrm{O}$ record from Site 590. From 3.4 to 2.2 $\mathrm{Ma}$, the average $\delta^{18} \mathrm{O}$ values in the planktonic record were lower (Fig. 6), whereas benthic $\delta^{18} \mathrm{O}$ values were increasing. Weissert et al. (1984) also noted this for sequences at similar latitudes $\left(\sim 30^{\circ} \mathrm{S}\right)$ in the South Atlan- tic. I concur with their interpretation that surface waters warmed by at least $2^{\circ} \mathrm{C}$ at these southern latitudes, when high-latitude glaciers were growing and bottom waters were cooling. Between 3.6 and $2.2 \mathrm{Ma}$ at Site 590 , a positive shift of $0.4 \%$ in benthic $\delta^{18} \mathrm{O}$ generally coincided with a negative shift of about $0.4 \%$ in planktonic $\delta^{18} \mathrm{O}$. Surface waters could have warmed by as much as $3^{\circ} \mathrm{C}$ if it is assumed that the oxygen isotope composition of ocean waters increased by $0.4 \%$ because of ice-volume accumulation. However, since the $\delta^{18} \mathrm{O}$ change in benthics was almost certainly caused, in part, by cooling of intermediate waters, the increase in surface waters would have probably been closer to $2^{\circ} \mathrm{C}$. Surface waters seem to have warmed over wide latitudinal areas extending from equatorial regions (Vergnaud Grazzini, 1980) to the warm subtropics (Weissert et al., 1984) between 3.4 and $2.2 \mathrm{Ma}$.

A further increase of about $0.4 \% 0$ in benthic $\delta^{18} \mathrm{O}$ occurred in the late Pliocene between 2.6 and $2.4 \mathrm{Ma}$. This isotopic shift heralds the beginning of Northern Hemisphere ice accumulation, as discussed previously (Backman, 1979; Prell, 1984; Shackleton et al., 1984).

The late Pliocene oxygen isotope trends are somewhat comparable to those that occurred during the early middle Miocene between 16 and $14 \mathrm{Ma}$; that is, they indicate a warming of surface waters at these middle latitudes at times of major ice accumulation at high latitudes.

It is perhaps significant that the transitions between the early and middle Miocene, the middle and late Miocene, the Miocene and Pliocene, and the preglacial and postglacial Pliocene were all marked by episodes of distinct climatic cooling. These stratigraphic boundaries were initially recognized in the classic, shallow-marine sequences exposed on land, on the basis of changes in lithofacies and shallow-water fossils, all susceptible to sea-level change (Loutit and Kennett, 1981) and largescale climatic change.

\section{Water Column Thermal Gradients}

The difference between benthic and planktonic $\delta^{18} \mathrm{O}$ values in the same samples $\left(\Delta^{18} \mathrm{O}\right.$ benthics - planktonics) is a measure of the temperature difference between surface and bottom waters, or the vertical temperature gradient. For Site 590 (Figs. 11 and 12), the average vertical $\delta^{18} \mathrm{O}$ gradient changed from about 1.75 during the early Miocene to about 2.25 during the middle and late Miocene and for much of the early Pliocene (a shift of $0.5 \%$ ). This is equivalent to about a $2{ }^{\circ} \mathrm{C}$ increase in the vertical temperature gradient between $1300 \mathrm{~m}$ and the ocean surface (assuming no salinity change occurred in surface waters). This increase in the southwest Pacific vertical temperature gradient occurred between 16 and $15 \mathrm{Ma}$, during the early middle Miocene (Fig. 12). During the intervals before and after this shift, the average thermal gradient did not change significantly, although there were large temporary oscillations, such as between 13 and $12 \mathrm{Ma}$. These results concur with those of Loutit, Kennett, et al. (1983), who suggested that much of the change that occurred in the thermal gradient in the Miocene occurred during the middle Miocene. 


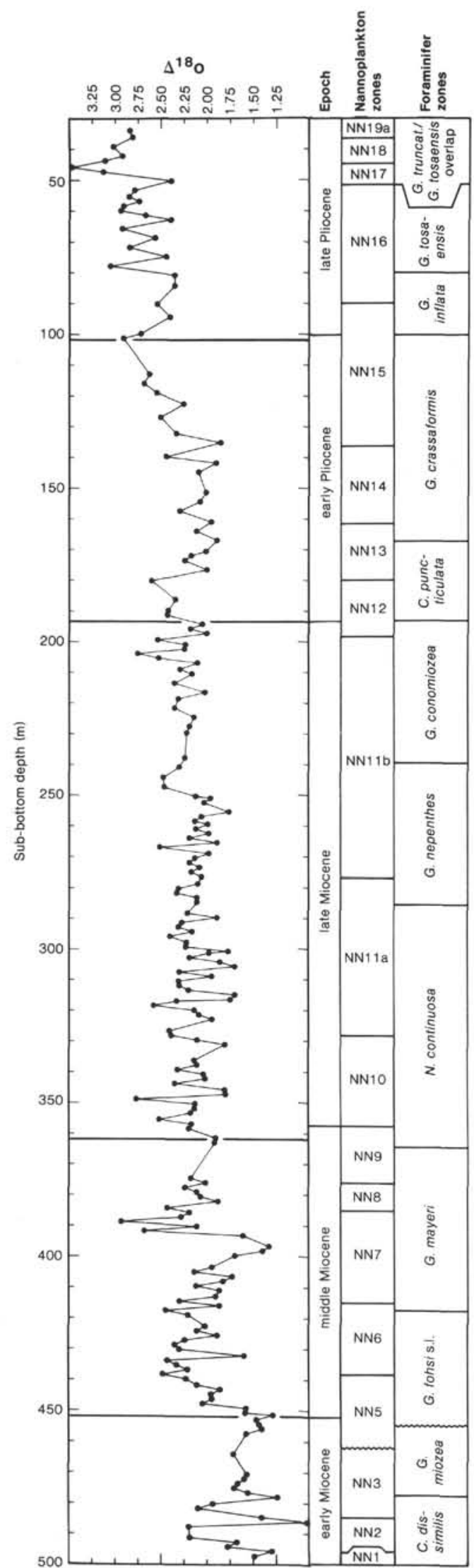

Figure 11. $\delta^{18} \mathrm{O}$ benthics - planktonics $\left(=\Delta^{18} \mathrm{O}\right)$ for Holes $590 \mathrm{~A}$ and $590 \mathrm{~B}$ plotted against depth for Site 590 and biostratigraphic zonations (see caption for Fig. 5). $\Delta^{18} \mathrm{O}$ represents the $\delta^{18} \mathrm{O}$ gradient between bottom waters (water depth $=1300 \mathrm{~m}$ ) and the ocean surface at Site 590.

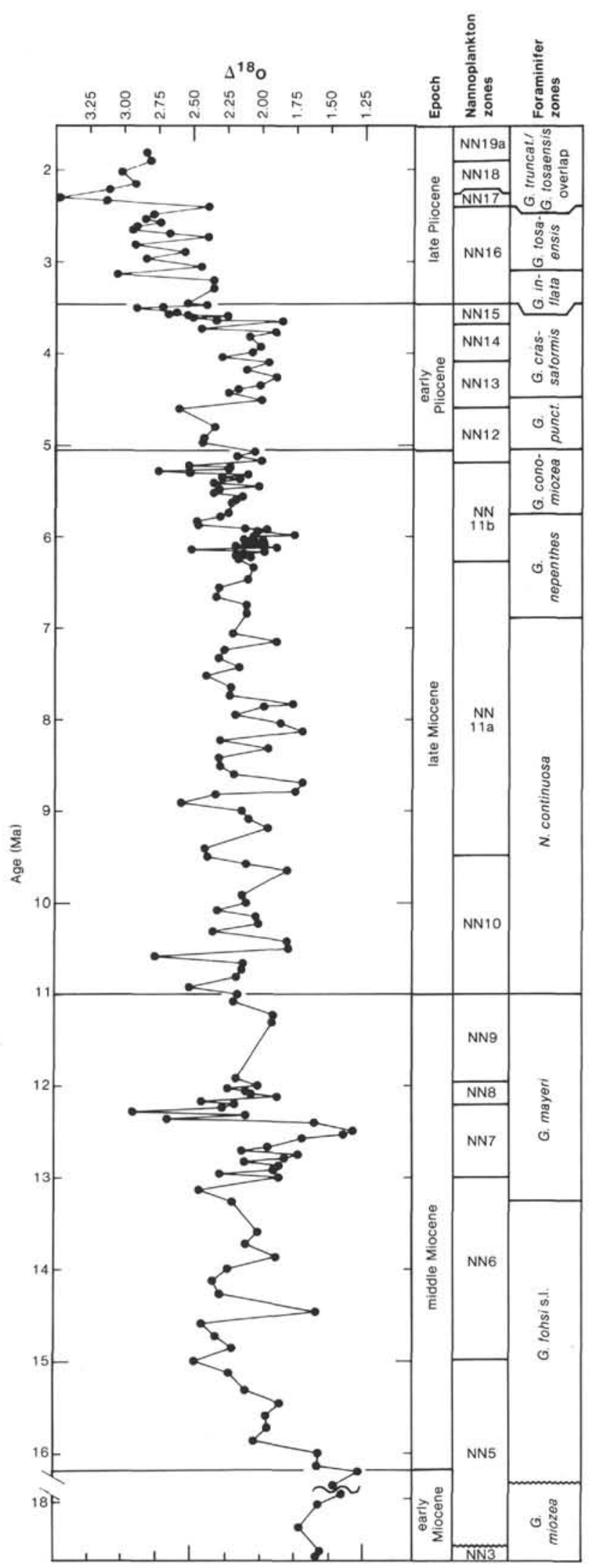

Figure $12 . \delta^{18} \mathrm{O}$ benthics - planktonics $\left(=\Delta^{18} \mathrm{O}\right)$ for Holes $590 \mathrm{~A}$ and $590 \mathrm{~B}$ plotted against age for Site 590 and biostratigraphic zonations (see caption for Fig. 5). $\Delta^{18} \mathrm{O}$ represents the $\delta^{18} \mathrm{O}$ gradient between bottom waters (water depth $=1300 \mathrm{~m}$ ) and the ocean surface at Site 590. Note unconformity between 16.5 and $18 \mathrm{Ma}$. 
Further distinct changes in the vertical temperature gradient occurred during the middle Pliocene at 3.6 Ma, with the average thermal gradient increasing by another $0.5 \%\left(\sim 2{ }^{\circ} \mathrm{C}\right)$, and during the late Pliocene at $2.4 \mathrm{Ma}$, with a further shift of 0.25 to $0.5 \%\left(\sim 1-2^{\circ} \mathrm{C}\right)$.

The records therefore document three permanent, rapid shifts in the vertical temperature gradient of the Neogene: (1) between 16 and $15 \mathrm{Ma}$ during the time of major accumulation of the large, permanent East Antarctic ice sheet; (2) at $\sim 3.5 \mathrm{Ma}$ during a time of further increased polar glaciation especially in the Antarctic; and (3) at $\sim 2.4 \mathrm{Ma}$ when Northern Hemisphere ice sheets began to form. There was little change in the average gradient between these three Neogene episodes. The vertical temperature gradient of the open ocean during the Neogene changed permanently only during times of largescale polar glacial development. As in middle latitudes of the South Atlantic (Hsü et al., 1984), middle-latitude South Pacific locations also record an increase in the vertical temperature gradient during the Neogene.

\section{CARBON ISOTOPES}

Work on Leg 90 sites revealed two major characteristics of carbon isotope stratigraphy. First, considerable similarity exists among the $\delta^{13} \mathrm{C}$ stratigraphies of all three sites and with those of other regions, especially with respect to the longer-term oscillations (Figs. 3, 6, and 9). Second, the planktonic and benthic $\delta^{13} \mathrm{C}$ changes are almost completely parallel, as shown in Site 590 (Fig. 6). This parallelism indicates that both surface and bottom waters are equally affected by changes in $\delta^{13} \mathrm{C}$ of oceanic $\mathrm{HCO}_{3}$, although average planktonic $\delta^{13} \mathrm{C}$ values are always about $1.25 \%$ higher than benthic $\delta^{13} \mathrm{C}$. The similarity of $\delta^{13} \mathrm{C}$ stratigraphies in the Neogene between different sites throughout the ocean basins has been recognized previously (Douglas and Savin, 1973; Loutit, Pisias, et al., 1983; Woodruff and Savin, 1985; Vincent and Berger, 1985). Shackleton and Kennett (1975b) noted a strong parallelism between South Pacific benthic and planktonic $\delta^{13} \mathrm{C}$ records during the middle and late $\mathrm{Ce}$ nozoic, as did Hsü et al. (1984) for the South Atlantic, Barrera et al. (in press) for the northeast Pacific, Vincent et al. (in press) for the tropical Indian Ocean, and Keigwin et al. (in press) for the North Atlantic. The similarity of the $\delta^{13} \mathrm{C}$ time-series records within and between ocean basins and between surface and bottom waters clearly indicates that oceanwide changes in average $\delta^{13} \mathrm{C}$ of $\mathrm{HCO}_{3}^{-}$in seawater, rather than local effects, dominated the records.

A major question concerns the origin of the changes in the benthic and planktonic $\delta^{13} \mathrm{C}$ records. Proposed causes of $\delta^{13} \mathrm{C}$ change through time include changes in sea level, continental hypsometry, continental biomass, vital effects, and oceanic circulation (Shackleton, 1977; Bender and Keigwin, 1979; Broecker, 1982; Loutit, Pisias, et al., 1983; Vincent et al., in press). Summarizing, Berger (1982) noted that the average oceanic $\delta^{13} \mathrm{C}$ composition will change as a result of several processes: the accumulation or release of organic carbon from temporary reservoirs on the continents and in the ocean ba- sins; changes in forest biomass; changes in ocean stratification and fertility; and changes in deep circulation and oxygenation. Oceanic $\delta^{13} \mathrm{C}$ values can be changed most rapidly by changing the flux of carbon from major carbon reservoirs: terrigenous carbon having $\delta^{13} \mathrm{C}$ values of about $-25 \%$ and marine carbon near $-20 \% 0$ (Craig, 1953; Sackett, 1964; Wedepohl, 1969). Broecker (1971) suggested that transgressions and regressions across the continental shelf could produce significant changes in open-ocean $\delta^{13} \mathrm{C}$ values. During transgressions, the shelves act as sinks for organic carbon. Conversely, during regressions, eroded sediment containing organic material depleted in ${ }^{13} \mathrm{C}$ is supplied to the oceans.

My preferred interpretation of the Neogene $\delta^{13} \mathrm{C}$ changes is that they were largely caused by average oceanic compositional changes resulting from fractionation between continental and oceanic organic carbon reservoirs. What caused this fractionation? Loutit, Pisias, et al. (1983) and Woodruff and Savin (1985) have shown that a correlation exists between changes in Neogene carbon isotopic stratigraphy and sea level as inferred from the onlap/offlap curve of Vail and Hardenbol (1979). During marine transgressions, organic carbon accumulated on the continental shelves, and ocean waters became more enriched in ${ }^{13} \mathrm{C}$ by the extraction of organic carbon (enriched in ${ }^{12} \mathrm{C}$ ). Conversely, during marine regression, organic carbon was delivered to the ocean basins and thus the oceans became more depleted in ${ }^{13} \mathrm{C}$. The transgressions and regressions were probably of large magnitude to account for the large changes in oceanic $\delta^{13} \mathrm{C}$ values and were controlled by fluctuations in sea level. The magnitude of the $\delta^{13} \mathrm{C}$ change depended upon the areas of shallow shelves covered or exposed by a given change in sea level. This, in turn, is directly related to the hypsometry of the continental margins and the magnitude of the sea-level change. A marine transgression that covered wide continental shelves provided a larger area for accumulation of organic carbon, and hence a larger increase in oceanic $\delta^{13} \mathrm{C}$ values.

Paleoclimatic change reinforced the $\delta^{13} \mathrm{C}$ changes. Global warming probably enhanced the accumulation of organic carbon in the continental reservoir by expansion of the biosphere through greater supply of moisture. Conversely, cooling led to greater aridity and reduction in size of the continental biosphere (Berger, 1982).

Superimposed upon the average $\delta^{13} \mathrm{C}$ of the oceans are a number of regional and local effects that have created gradients from region to region and with water depth. For example, Kroopnick $(1974,1980,1985)$ documented the fact that different water masses have diferent $\delta^{13} \mathrm{C}$ signatures depending upon source and addition of metabolic $\mathrm{CO}_{2}$ along the flow path. The mechanisms that controlled this variation in the past are less well understood, but include local and regional differences in biological productivity of surface waters, changes in deep-water circulation patterns, changes in the $\delta^{13} \mathrm{C}$ of $\mathrm{HCO}_{3}^{-}$in the source regions of bottom-water formation, and the amount of organic carbon that has been oxidized to form ${ }^{12} \mathrm{C}$-enriched $\mathrm{HCO}_{3}^{-}$in deep waters following its formation at high latitudes (Loutit, Pisias, et al., 1983). 


\section{Early Neogene Carbon Isotope Excursion}

The dominant feature of Neogene carbon isotope stratigraphy is the broad late early to early middle Miocene maximum of about $1 \%$ which Vincent et al. (in press) and Vincent and Berger (1985) have termed the "Monterey Carbon Isotope Excursion." This excursion is best exhibited at Site 588 (at Site 590, part of the excursion is missing because of the hiatus), where it began as a shift toward increased $\delta^{13} \mathrm{C}$ values at about $19.5 \mathrm{Ma}$ (within Zone NN2). The excursion consists of broad peaks centered at $19 \mathrm{Ma}, 16.5 \mathrm{Ma}$, and about 15 to $15.5 \mathrm{Ma}$. As shown in Sites 588 and 590, the decline from the high values began within the middle Miocene between 15 and $14 \mathrm{Ma}$ and continued with little interruption until 13 Ma. This negative shift began about midway through the distinct, early middle Miocene increase in benthic $\delta^{18} \mathrm{O}$ values, and is contemporaneous with the trend toward more positive planktonic $\delta^{18} \mathrm{O}$ values (Figs. 3 and 6).

As several previous workers have proposed, I concur that the origin of this carbon isotopic excursion was due to global marine transgression (Loutit, Pisias, et al., 1983; Vincent et al., in press; Woodruff and Savin, 1985). According to Vincent et al. (in press) and Vincent and Berger (1985) widespread transgression during this excursion occurred throughout the circum-Pacific region and created major sinks for organic carbon. Organic and phosphate-rich deposits accumulated within the Monterey Formation of California and other contemporaneous deposits throughout the Pacific margin. Vail and Hardenbol (1979) documented a period of coastal onlap that began at about $19 \mathrm{Ma}$ and terminated about $14 \mathrm{Ma}$, and was contemporaneous with the interval containing the especially positive $\delta^{13} \mathrm{C}$ values (Figs. 3, 6, and 9).

This excursion also corresponded to the maximum ocean temperatures of the Neogene as reflected in benthic and planktonic $\delta^{18} \mathrm{O}$ values. Because the late early Miocene was the time of optimum climatic warming during the Neogene, tropical forests were probably widespread and the continental organic biosphere would have been more extensive than at other times. The high continental biomass at this time would have contributed to the positive $\delta^{13} \mathrm{C}$ values during this interval. Global cooling during the middle Miocene probably led to greater aridity and reduction of the terrestrial biomass, resulting in a lowering of oceanic $\delta^{13} \mathrm{C}$ values during the middle Miocene.

At Site 590, the warming of surface waters during the early stage of the benthic $\delta^{18} \mathrm{O}$ shift suggests that the early part of that shift may have resulted largely from decreasing temperatures at high latitudes rather than from increasing ice accumulation. If little ice had accumulated at that point, then glacioeustatic regression would not have occurred. The $\delta^{13} \mathrm{C}$ (benthic and planktonic) began to decrease, suggesting regression, at about 14.5 $\mathrm{Ma}$, when the $\delta^{18} \mathrm{O}$ shift occurred in both the benthic and planktonic records. It is possible that this synchronous enrichment in both planktonic and benthic $\delta^{18} \mathrm{O}$ represents the major ice-growth phase of East Antarcti$\mathrm{ca}$. If this scenario is correct, then major ice accumula- tion and resulting regression occurred between 14.5 Ma and $13 \mathrm{Ma}$.

Following the carbon isotope excursion, during the latest middle Miocene, further changes in $\delta^{13} \mathrm{C}$ occurred, including a trend toward lower values that was centered in the earliest late Miocene at $11 \mathrm{Ma}$. A return to markedly increased benthic $\delta^{13} \mathrm{C}$ values occurred during the middle part of the late Miocene, especially between 10 and $7 \mathrm{Ma}$.

\section{Latest Miocene Carbon Isotope Shift}

The latest Miocene at $6.2 \mathrm{Ma}$ is marked by a distinct, rapid $\delta^{13} \mathrm{C}$ shift of up to $-0.75 \%$ in all of the southwest Pacific sites, both in the benthic and planktonic records. This depletion in ${ }^{13} \mathrm{C}$ was followed by markedly low values during much of the remainder of the late Neogene, which lead to the suggestion that it was "permanent" (Keigwin, 1979). This well-known late Miocene carbon isotope shift is recorded throughout the Indo-Pacific and South Atlantic (Keigwin, 1979; Bender and Keigwin, 1979; Loutit and Kennett, 1979; Keigwin and Shackleton, 1980; Vincent et al., 1980; Haq et al., 1980; Hodell and Kennett, 1984). This shift, which seems to have occurred within a period of not much more than $100,000 \mathrm{yr}$. (Vincent et al., 1980), was assigned an age of $\sim 6 \mathrm{Ma}$ by $\mathrm{Haq}$ et al. (1980) and of 6.2 Ma by Loutit and Kennett (1979), and was recently estimated at $6.4 \mathrm{Ma}$ (Barron et al., in press). The magnitude of the shift throughout the IndoPacific region is generally reported to be about $-1 \% 0$ (Haq et al., 1980); in the South Atlantic a shift of 0.7\% has been estimated by Hodell, Elmstrom, and Kennett (unpublished data). Numerous climatic and oceanographic events closely associated with the carbon shift have been summarized by Loutit and Keigwin (1982) (for additional references see therein) and include the following: lowering of sea level; cooling of high- and middle-latitude surface waters; isolation and dessication of the Mediterranean Basin; increase in bottom-water circulation and fertility of the oceans: increase in biogenic siliceous deposits in the Southern Ocean; decrease of biogenic siliceous sedimentation rates in the eastern equatorial $\mathrm{Pa}$ cific; shoaling of the Isthmus of Panama; a change, in the North Atlantic, from a calcite compensation depth (CCD) shallower than that in the Pacific to one deeper than the Pacific CCD; and an increase in deep-sea sedimentation rates. During the latest Miocene, the CCD experienced a sharp fall of at least several hundred meters (van Andel et al., 1977), or even up to $1 \mathrm{~km}$ in the South Atlantic (Hsü et al., 1984).

Numerous hypotheses have been proposed for the cause of the carbon isotope shift, including a change in the rate of organic carbon buried in the oceans and in the rate of upwelling and ocean fertility (Bender and Keigwin, 1979). The carbon shift is believed by some to have been caused by an increase in the flux of organic matter from coastal lowlands and continental shelves exposed by regression (Loutit and Keigwin, 1982; Vincent et al., 1980; Loutit, Pisias, et al., 1983), reinforced by increased oceanic fertility (Vincent et al., 1980). The close temporal association of the carbon shift with global regression (Kennett, 1967; Adams et al., 1977; Vail and Harden- 
bol, 1979), which is inferred to have resulted from glacioeustatic lowering of sea level (Kennett, 1967; Loutit and Kennett, 1979; Mercer and Sutter, 1982) in the latest Miocene, makes this theory very compelling. Estimates of the magnitude of the marine regression are similar, ranging from 40 to $80 \mathrm{~m}$ (Loutit and Kennett, 1979; Berggren and Haq, 1976; Cita and Ryan, 1979).

The drop in the CCD throughout the oceans has an origin similar to that of the carbon isotope shift, having resulted from an increase in the fractionation of carbonate and organic carbon entering the deep basins from the continental shelves during the latest Miocene regression (Berger, 1970; Ciesielski et al., 1982). This sea-level fall was also sufficient to isolate the Mediterranean and initiate the "Messinian Salinity Crisis" (Cita, 1982) between about 5.7 and 5.2 Ma. Previous work has indicated that the sea-level fall was largely glacioeustatic because of the rapidity of the fall and its association with surface-water cooling at middle and high latitudes (Kennett, 1967; Kennett and Watkins, 1974; Loutit and Kennett, 1979; Loutit, 1981) and with a period of relatively high $\delta^{18} \mathrm{O}$ values (Shackleton and Kennett, 1975a; Kennett et al., 1979; Loutit and Kennett, 1979; Ciesielski et al., 1982; McKenzie et al., 1984).

\section{Early Pliocene Events}

During the Pliocene (as shown by Site 590), average benthic $\delta^{13} \mathrm{C}$ values were lower by about $0.25 \%$, planktonic $\delta^{13} \mathrm{C}$ by about $0.75 \%$, than during the Miocene preceding the carbon shift. An interval of relatively increased values occurred in the early Pliocene, between about 5 and $4 \mathrm{Ma}$. This interval corresponds with a period of relative global warmth (Kennett, 1967; Loutit and Kennett, 1979; Ingle, 1967; McKenzie et al., 1984); global marine transgression (Kennett, 1967; Kennett and Watkins, 1974; Vail and Hardenbol, 1979); relatively low $\delta^{18} \mathrm{O}$ values in benthic foraminifers as shown at Site 590 and in records elsewhere (McKenzie et al., 1984; Hodell, Elmstrom, and Kennett, unpublished data), reflecting a decrease in global ice volume; and a marine transgression in the Mediterranean with restoration of pelagic sedimentation. I suggest that the early Pliocene interval of high $\delta^{13} \mathrm{C}$ values resulted from marine transgression. Details for this interval are provided in Elmstrom and Kennett (this volume).

\section{CONCLUSIONS}

1. A high-resolution study of benthic and planktonic oxygen and carbon isotope stratigraphy was conducted for the Miocene to early Pliocene in high-quality DSDP Sites 588, 590, and 591, from the southwest $\mathrm{Pa}$ cific (warm-subtropical to transitional latitudes). Sample resolution for much of the Miocene is between $\sim 25,000$ and 50,000 yr. and for the Pliocene between 5,000 and 15,000 yr.

2. The climax of Neogene warmth, marked by the lowest $\delta^{18} \mathrm{O}$ values of the Neogene, occurred during the late early Miocene, between $\sim 19.5$ and $16.5 \mathrm{Ma}$.

3 . This climatic warming was immediately followed by a major increase in $\delta^{18} \mathrm{O}$ values between $\sim 16.5$ and 13.5 Ma. This event is interpreted as representing major, permanent accumulation of the East Antarctic ice sheet and cooling of bottom waters; it lasted $3 \mathrm{~m}$.y. Surface waters at these middle latitudes warmed during the first half of the ice volume increase, but cooled at higher latitudes.

4. The late Miocene began, in the earliest part (11 to $9 \mathrm{Ma}$ ), with a distinct climatic cooling that is chronicled by the highest $\delta^{18} \mathrm{O}$ for the Miocene. This was followed by relative warmth during the middle part of the late Miocene, between $\sim 9$ and $6.5 \mathrm{Ma}$.

5. The latest Miocene and early Pliocene (6.2 to 4.5 $\mathrm{Ma}$ ) were marked by increased $\delta^{18} \mathrm{O}$ values, indicating increased cooling and glacial development in the Southern Hemisphere.

6. During the middle Pliocene at about $3.4 \mathrm{Ma}$, a $0.4 \%$ increase in benthic $\delta^{18} \mathrm{O}$ documents a net change in average global ice volume and cooling of bottom waters. During this increase in Southern Hemisphere glaciation, surface waters warmed by $2-3^{\circ} \mathrm{C}$ in middle-latitude regions of the Southern Hemisphere.

7. During the late Pliocene between 2.6 and 2.4, a further increase in benthic $\delta^{18} \mathrm{O}$ heralded the development of large ice sheets on the Northern Hemisphere.

8. Surface-water warming in the middle latitudes occurred in association with major high-latitude glacial increases in the early middle Miocene (16-14 Ma), middle Pliocene ( $3.5 \mathrm{Ma})$, and late Pliocene $(\sim 2.4 \mathrm{Ma})$. These intervals were also marked by increases in the vertical temperature gradient in the open ocean. At intervening times, the gradient remained unchanged.

9. Transitions between the early and middle Miocene, the middle and late Miocene, the Miocene and Pliocene, and the "preglacial" and "postglacial" Pliocene were marked by distinct episodes of climatic cooling.

10. A high similarity of the $\delta^{13} \mathrm{C}$ time-series records within and between ocean basins and between surface and bottom waters clearly indicates that ocean wide changes in the average $\delta^{13} \mathrm{C}_{\text {of }} \mathrm{HCO}_{3}^{-}$in seawater dominated the records, rather than local effects. Broad changes in the Neogene $\delta^{13} \mathrm{C}$ record were caused largely by transfers of organic carbon between continental and oceanic reservoirs. These transfers resulted from marine regressions and transgressions on the continental margins. During transgressions, organic carbon, which has low $\delta^{13} \mathrm{C}$ values, accumulated on the continental shelves, and ocean waters thus increased in $\delta^{13} \mathrm{C}$. Conversely, during marine regressions, organic carbon was delivered to the ocean basins and the oceans became lower in $\delta^{13} \mathrm{C}$. Paleoclimatic changes reinforced these $\delta^{13} \mathrm{C}$ changes by influencing the size of continental biomass.

11. The dominant feature of Neogene $\delta^{13} \mathrm{C}$ stratigraphy is a broad maximum of about $1 \%$ between $\sim 19$ and $14.5 \mathrm{Ma}$. This excursion occurred contemporaneously with a period of maximum coastal onlap (transgression) and maximum Neogene climatic warmth. The excursion terminated during the expansion of the Antarctic ice sheet and associated marine regression in the early middle Miocene (15.5-14.5 Ma).

12. The latest Miocene carbon isotope shift (of up to $-0.75 \%$ ) at $6.2 \mathrm{Ma}$ is clearly recorded in the sites examined, and was followed by generally low $\delta^{13} \mathrm{C}$ values dur- 
ing the remainder of the Neogene. This shift may have been caused by an increase in the flux of organic matter from continental marginal areas exposed by regression, which was, in turn, triggered by glacioeustatic lowering of the sea level.

13. An increase in $\delta^{13} \mathrm{C}$ values during the early Pliocene $(\sim 5$ to $4 \mathrm{Ma})$ resulted from marine transgression during a time of global warmth.

\section{ACKNOWLEDGMENTS}

I wish to thank J. Orchardo for his meticulous care in producing the stable isotope data. Valuable conversations about this work with D. Hodell and N. Shackleton are appreciated. I thank D. Hodell for his most valuable constructive criticism of the manuscript, which was typed by N. Meader. The manuscript also benefited from constructive reviews by L. Keigwin, S. Savin, T. Loutit, and N. Shackleton. Thanks are also due to R. Ross, K. Nelson, and R. Rice for picking foraminifers for the analyses and to $\mathrm{K}$. Nelson for producing the data plots and for general assistance. J. Peck also lent useful general assistance.

This research was supported by the U.S. National Science Foundation Grant No. OCE82-14937 (Submarine Geology and Geophysics).

\section{REFERENCES}

Adams, C. G., Benson, R. H., Kidd, R. B., Ryan, W. B. F., and Wright, R. C., 1977. The Messinian salinity crisis and evidence of late Miocene eustatic changes in the world ocean. Nature, 269: 383-386.

Backman, J., 1979. Pliocene biostratigraphy of DSDP Sites 111 and 116 from the North Atlantic Ocean and the age of Northern Hemisphere glaciation. Stockholm Contrib. Geol., 32(3):115-135.

Bandy, O. L., Casey, R. E., and Wright, R. C., 1971. Late Neogene Planktonic Zonation, Magnetic Reversals, and Radiometric Dates, Antarctic to the Tropics. Am. Geophys. Un. Antarctic Ser., 15.

Barrera, E., Keller, G., and Savin, S. M., in press. Evolution of the Miocene Ocean in the eastern North Pacific as inferred from oxygen and carbon isotopic ratios of foraminifera. In Kennett, J. P. (Ed.), The Miocene Ocean: Paleoceanography and Biogeography. Geol. Soc. Am. Mem., 163.

Barron, J. A., Keller, G., and Dunn, D. A., in press. A multiple microfossil biochronology for the Miocene. In Kennett, J. P. (Ed.), The Miocene Ocean: Paleoceanography and Biogeography. Geol. Soc. Am. Mem., 163.

Bender, M. L., and Keigwin, L. D., Jr., 1979. Speculations about the upper Miocene change in abyssal Pacific dissolved bicarbonate $\delta^{13} \mathrm{C}$. Earth Planet. Sci. Lett., 45:383-393.

Berger, W. H., 1970. Planktonic Foraminifera in selective solution and the lysocline. Mar. Geol., 8:111-183.

1982. Deep-sea stratigraphy: Cenozoic climate steps and the search for chemo-climatic feedback. In Einsele, G., and Seilacher, A. (Eds.), Cyclic and Event Stratification: Berlin (Springer-Verlag), pp. 121-157.

Berger, W. H., Killingley, J. S., and Vincent, E., 1978. Stable isotopes in deep-sea carbonates: Box Core ERDC-92, West Equatorial Pacific. Oceanol. Acta, 1:203-216.

Berggren, W. A., 1981. Correlation of Atlantic, Mediterranean and Indo-Pacific Neogene stratigraphies: geochronology and chronostratigraphy. Proc., IGCP-114 Int. Workshop Pacific Neogene Biostratigraphy, Nov. 25-29, 1981, Osaka, Japan, pp. 29-60.

Berggren, W. A., and Haq, B. U., 1976. The Andalusian Stage (late Miocene): biostratigraphy, biochronology, and paleoecology. $\mathrm{Pa}$ laeogeogr., Palaeoclimatol., Palaeoecol., 20:67-129.

Berggren, W. A., Kent, D. V., and Flynn, J. J., 1985. Paleogene geochronology and chronostratigraphy. In Snelling, N. J. (Ed.), Geochronology and the Geological Record. Geol. Soc. London, Spec. Pap.

Berggren, W. A., Kent, D. V., and Van Couvering, J. A., 1985. Neogene geochronology and chronostratigraphy. In Snelling, N. J. (Ed.), Geochronology and the Geologic Time Scale. Geol. Soc. London, Spec. Pap.

Brewster, N. A., 1980. Cenozoic biogenic silica sedimentation in the Antarctic Ocean, based on two Deep Sea Drilling Project sites. Geol. Soc. Am. Bull., 91:337-347.
Broecker, W. S., 1971. A kinetic model for the chemical composition of seawater. Quat. Res., 1:188-207.

1982. Ocean chemistry during glacial time. Geochim. Cosmochim. Acta, 46:1689-1705.

Burckle, L. H., Keigwin, L. D., and Opdyke, N. D., 1982. Middle and late Miocene stable isotope stratigraphy: correlation to the paleomagnetic reversal record. Micropaleontology, 28(4):329-334.

Ciesielski, P. F., Ledbetter, M. T., and Ellwood, B. B., 1982. The development of Antarctic glaciation and the Neogene paleoenvironment of the Maurice Ewing Bank. Mar. Geol., 46:1-52.

Ciesielski, P. F., and Weaver, F. M., 1974. Early Pliocene temperature changes in the Antarctic seas. Geology, 2:511-515.

Cita, M. B., 1976. Biodynamic effects of the Messinian salinity crisis on the evolution of planktonic foraminifers in the Mediterranean. Palaeogeogr., Palaeoclimatol., Palaeoecol., 20:23-42.

1982. The Messinian salinity crisis in the Mediterranean: A review. Alpine Mediterranean Geodynamics Series (Vol. 7): Washington (Am. Geophys. Un.), 113-140.

Cita, M. B., and Ryan, W. B. F., 1979. Late Neogene environmental evolution. In von Rad, U., Ryan, W. B. F., et al., Init. Repts. DSDP, 47 (Pt. 1): Washington (U.S. Govt. Printing Office), 447459.

Craig, H., 1953. The geochemistry of the stable carbon isotopes. Geochim. Cosmochim. Acta, 3:53-92.

Davies, T. A., Hay, W. W., Southam, J. R., and Worsley, T. R., 1977. Estimates of Cenozoic oceanic sedimentation rates. Science, 197: 53-55.

Denham, R. N., and Crook, F. G., 1976. The Tasman Front. N.Z.J. Mar. Freshwater Res., 10:15-30.

Douglas, R. G., and Savin, S. M., 1973. Oxygen and carbon isotope analyses of Cretaceous and Tertiary Foraminifera from the central north Pacific. In Winterer, E. L., Ewing, J. I., et al., Init. Repts. $D S D P$, 17: Washington (U.S. Govt. Printing Office), 591-605.

Epstein, S., Buchsbaum, R., Lowenstam, H. A., and Urey, H. C., 1953. Revised carbonate-water isotopic temperature scale. Geol. Soc. Am. Bull., 64:1315-1326.

Haq, B. U., 1980. Biogeographic history of Miocene calcareous nannoplankton and paleoceanography of the Atlantic Ocean. Micropaleontology, 26(4):414-443.

Haq, B. U., Worsley, T. R., Burckle, L. H., Douglas, R. G., Keigwin, L. D., Jr., Opdyke, N. D., Savin, S. M., Sommer, M. A. II, Vincent, E., and Woodruff, F., 1980. Late Miocene marine carbonisotopic shift and synchroneity of some phytoplanktonic biostratigraphic events. Geology, 8:427-431.

Hodell, D., and Kennett, J. P., 1984. Late Miocene carbon shift in DSDP Site 516A, western south Atlantic. GSA Abstr. Progr., 16(6): 540.

Hsü, K. J., Cita, M. B., and Ryan, W. B. F., 1973. The origin of the Mediterranean evaporites. In Ryan, W. B. F., Hsü, K. J., et al., Init. Repts. DSDP, 13(Pt. 2): Washington (U.S. Govt. Printing Office), 1203-1231.

Hsü, K. J., McKenzie, J. A., Oberhänsli, H., Weissert, H., and Wright, R. C., 1984. South Atlantic Cenozoic paleoceanography. In Hsü, K. J., LaBrecque, J. L., et al., Init. Repts. DSDP, 73: Washington (U.S. Govt. Printing Office), 771-785.

Ingle, J. C., 1967. Foraminiferal biofacies variation and the MiocenePliocene boundary in Southern California. Bull. Am. Paleontol., 52:217-394

1973. Neogene foraminifera from the northeastern Pacific Ocean, Leg 18, Deep Sea Drilling Project. In Kulm, L. D., von Huene, R., et al., Init. Repts. DSDP, 18: Washington (U.S. Govt. Printing Office), 517-567.

Keany, J., 1978. Paleoclimatic trends in early and middle Pliocene deepsea sediments of the Antarctic. Mar. Micropaleontol., 3:35-49.

Keigwin, L. D., Jr., 1976. Late Cenozoic planktonic foraminiferal biostratigraphy and paleoceanography of the Panama Basin. Micropaleontology, 22:419-440.

1979. Late Cenozoic stable isotope stratigraphy and paleoceanography of DSDP sites from the east equatorial and central north Pacific Ocean. Earth Planet. Sci. Lett., 45:361-382.

Keigwin, L. D., Aubry, M.-P., and Kent, D. V., in press. Upper Miocene stable isotopic stratigraphy, biostratigraphy, and magnetostratigraphy of North Atlantic DSDP Sites. In Ruddiman, W. F., Kidd, R. B., et al., Init. Repts. DSDP, 94: Washington (U.S. Govt. Printing Office). 
Keigwin, L. D., Jr., and Shackleton, N. J., 1980. Uppermost Miocene carbon isotope stratigraphy of a piston core in the equatorial $\mathrm{Pa}$ cific. Nature, 284(5757):613-614.

Keigwin, L. D., Jr., and Thunell, R. C., 1980. Middle Pliocene climatic change from faunal and oxygen isotopic trends: western Mediterranean. Nature, 282(5736):294-296.

Keller, G., 1979. Late Neogene planktonic foraminiferal biostratigraphy and paleoceanography of the Northwest Pacific Site 296. Palaeogeogr., Palaeoclimatol., Palaeoecol., 27:129-154.

Kennett, J. P., 1967. Recognition and correlation of the Kapitean Stage (upper Miocene, New Zealand). N.Z.J. Geol. Geophys., 10:10511063.

1977. Cenozoic evolution of Antarctic glaciation, the circum-Antarctic ocean and their impact on global paleoceanography. J. Geophys. Res., 82(27):3843-3859.

Kennett, J. P., Keller, G., and Srinivasan, M. S., in press. Miocene planktonic foraminiferal biogeography and paleoceanographic development of the Indo-Pacific region. In Kennett, J. P. (Ed.), The Miocene Ocean: Paleoceanography and Biogeography. Geol. Soc. Am. Mem., 163.

Kennett, J. P., Shackleton, N. J., Margolis, S. V., Goodney, D. E., Dudley, W. C., and Kroopnick, P. M., 1979. Late Cenozoic oxygen and carbon isotopic history and volcanic ash stratigraphy: DSDP Site 284, South Pacific. Am. J. Sci., 279:52-69.

Kennett, J. P., and Vella, P., 1975. Late Cenozoic planktonic foraminifera and paleoceanography at DSDP Site 284 in the cool subtropical South Pacific. In Kennett, J. P., Houtz, R. E., et al., Init. Repts. DSDP, 29: Washington (U.S. Govt. Printing Office), 769799.

Kennett, J. P., and Watkins, N. D., 1974. Late Miocene-early Pliocene paleomagnetic stratigraphy, paleoclimatology, and biostratigraphy in New Zealand. Geol. Soc. Am. Bull., 85:1385-1398.

Killingley, J. S., Johnson, R. F., and Berger, W. H., 1981. Oxygen and carbon isotopes of individual shells of planktonic foraminifera from Ontong-Java plateau, equatorial Pacific. Palaeogeogr., Palaeoclimatol., Palaeoecol., 33:193-204.

Knox, G. A., 1970. Biological oceanography of the South Pacific. In Wooster, W. A. (Ed.), Scientific Exploration of the South Pacific: Washington (National Academy of Sciences), pp. 155-182.

Kroopnick, P., 1974. The dissolved $\mathrm{O}_{2}-\mathrm{CO}_{2}-{ }^{13} \mathrm{C}$ system in the eastern equatorial Pacific. Deep-Sea Res., 21:211-227.

1980. The distribution of $\delta^{13} \mathrm{C}$ in the Atlantic Ocean. Earth Planet. Sci. Lett., 49:469-484.

1985. The distribution of ${ }^{13} \mathrm{C}$ of $\Sigma \mathrm{CO}_{2}$ in the world oceans. Deep-Sea Res., 32:57-84.

Loutit, T. S., 1981. Late Miocene paleoclimatology: subantarctic water mass, southwest Pacific. Mar. Micropaleontol., 6:1-27.

Loutit, T. S., and Keigwin, L. D., Jr., 1982. Stable isotopic evidence for latest Miocene sea-level fall in the Mediterranean region. $\mathrm{Na}$ ture, 300(5888):163-166.

Loutit, T. S., and Kennett, J. P., 1979. Application of carbon isotope stratigraphy to late Miocene shallow marine sediments, New Zealand. Science, 204:1196-1199.

1981. New Zealand and Australian Cenozoic sedimentary cycles and global sea-level changes. Am. Assoc. Pet. Geol. Bull., 65:1586-1601.

Loutit, T. S., Kennett, J. P., and Savin, S. M., 1983. Miocene equatorial and southwest Pacific paleoceanography from stable isotope evidence. Mar. Micropaleontol., 8:215-233.

Loutit, T. S., Pisias, N. G., and Kennett, J. P., 1983. Pacific Miocene carbon isotope stratigraphy using benthic foraminifera. Earth Planet. Sci. Lett., 66:48-62.

McKenzie, J. A., Weissert, H., Poore, R. Z., Wright, R. C., Percival, S. F., Jr., Oberhänsli, H., and Casey, M., 1984. Paleoceanographic implications of stable-isotope data from upper Miocene-lower Pliocene sediments from the southeast Atlantic (Deep Sea Drilling Project Site 519). In Hsü, K. J., LaBrecque, J. L., et al., Init. Repts. DSDP, 73: Washington (U.S. Govt. Printing Office), $717-$ 724.

Margolis, S. V., Kroopnick, P. M., Goodney, D. E., Dudley, W. C., and Mahoney, M. E., 1975. Oxygen and carbon isotopes from calcareous nannofossils as paleoceanographic indicators. Science, 189: 555-557.

Matthews, R. K., Curry, W. B., Lohmann, K. C., and Sommer, M. A., 1980. Late Miocene palaeo-oceanography of the Atlantic: oxy- gen isotope data on planktonic and benthic Foraminifera. Nature, 283:555-557.

Matthews, R. K., and Poore, R. Z., 1980. Tertiary $\delta^{18} \mathrm{O}$ record and glacio-eustatic sea-level fluctuations. Geology, 8:501-504.

Mercer, J. H., 1976. Glacial history of southernmost South America. Quat. Res., 6:125-166.

Mercer, J. H., and Sutter, J. F., 1982. Late Miocene-earliest Pliocene glaciation in southern Argentina: implications for global ice-sheet history. Palaeogeogr., Palaeoclimatol., Palaeoecol., 38:185-206.

Poore, R. Z., 1981. Late Miocene biogeography and paleoclimatology of the central North Atlantic. Mar. Micropaleontol., 6:599-616.

Prell, W. L., 1984. Covariance patterns of foraminifera $\delta^{18} \mathrm{O}$ : an evaluation of Pliocene ice volume changes near 3.2 million years ago. Science, 206:692-693.

Prell, W. L., Gardner, J. V., et al., 1982. Init. Repts. DSDP, 68: Washington (U.S. Govt. Printing Office).

Sackett, W. M., 1964. The depositional history and isotopic organic carbon composition of marine sediments. Mar. Geol., 2:173-185.

Savin, S. M., Abel, L., Barrera, E., Hodell, D., Keller, G., Kennett, J. P., Killingley, J., Murphy, M., and Vincent, E., in press. The evolution of Miocene surface and near-surface marine temperatures: oxygen isotopic evidence. In Kennett, J. P. (Ed.), The Miocene Ocean: Palaeoceanography and Biogeography. Geol. Soc. Am. Mem., 163.

Savin, S. M., Douglas, R. G., Keller, G., Killingley, J. S., Shaughnessy, L., Sommer, M. A., Vincent, E., and Woodruff, F., 1981. Miocene benthic foraminiferal isotope records: A synthesis. Mar. Micropaleontol., 6:423-450.

Savin, S. M., Douglas, R. G., and Stehli, F. G., 1975. Tertiary marine paleotemperatures. Geol. Soc. Am. Bull., 86:1499-1510.

Schnitker, D., 1980. North Atlantic oceanography as possible cause of Antarctic glaciation and eutrophication. Nature, 287:615-616.

Sclater, J., Meinke, L., Bennett, A., and Murphy, C., in press. The depth of the ocean through the Neogene. In Kennett, J. P. (Ed.), The Miocene Ocean: Paleoceanography and Biogeography. Geol. Soc. Am. Mem., 163.

Shackleton, N. J., 1977. Carbon-13 in Uvigerina: tropical rain forest history and the equatorial Pacific carbonate dissolution cycles. In Anderson, N. R., and Malahoff, A. (Eds.), The Fate of Fossil Fuel $\mathrm{CO}_{2}$ in the Oceans: New York (Plenum), pp. 401-427.

Shackleton, N. J., Backman, J., Zimmerman, H., et al., 1984. Oxygen isotope calibration of the onset of ice rafting and history of glaciation in the North Atlantic region. Nature, 307(5952):620-623.

Shackleton, N. J., and Cita, M. B., 1979. oxygen and carbon isotope stratigraphy of benthic foraminifers at Site 597: detailed history of climatic change during the late Neogene. In von Rad, U., Ryan, W. B. F., et al., Init. Repts. DSDP, 47(Pt.1): Washington (U.S. Govt. Printing Office), 433-445.

Shackleton, N. J., and Kennett, J. P., 1975a. Late Cenozoic oxygen and carbon isotopic changes at DSDP Site 284: Implications for glacial history of the Northern Hemisphere and Antarctica. In Kennett, J. P., Houtz, R. E., et al., Init. Repts. DSDP, 29: Washington (U.S. Govt. Printing Office), 801-806.

1975b. Paleotemperature history of the Cenozoic and the initiation of Antarctic glaciation: Oxygen and carbon isotope analyses in DSDP Sites 277, 279, and 281. In Kennett, J. P., Houtz, R. E., et al., Init. Repts. DSDP, 29: Washington (U.S. Govt. Printing Office), 743-755.

Shackleton, N. J., and Opdyke, N. D., 1977. Oxygen isotopic and paleomagnetic evidence for early Northern Hemisphere glaciation. Nature, 270:216-219.

Stanton, B. R., 1979. The Tasman Front. N.Z.J. Mar. Freshwater Res., 138:201-214.

1981. An oceanographic survey of the Tasman Front. N.Z.J. Mar. Freshwater Res., 15:289-297.

Vail, P. R., and Hardenbol, J., 1979. Sea-level changes during the Tertiary. Oceanus, 22:71-79.

van Andel, T. H., Thiede, J., Sclater, J. G., and Hay, W. W., 1977. Depositional history of the South Atlantic ocean during the last 125 million years. J. Geol., 85:651-698.

Vergnaud Grazzini, C., and Rabussier-Lointier, D., 1980. Essai de correlation stratigraphique par le moyen des iotopes de l'oxygène et du carbone. Soc. Geol. France, 22(7):719-730.

Vincent, E., and Berger, W. H., 1985. Carbon dioxide and polar cooling in the Miocene: The Monterey hypothesis. In Sundquist, E. T., 
and Broecker, W. S. (Ed.), The Carbon Cycle and Atmospheric $\mathrm{CO}_{2}$ : natural Variations Archean to Present: Am. Geophys. Union Monogr. Ser., 32.

Vincent, E., Killingley, J. S., and Berger, W. H., 1980. The magnetic Epoch-6 carbon shift: a change in the ocean's ${ }^{13} \mathrm{C} /{ }^{12} \mathrm{C}$ ratio 6.2 million years ago. Mar. Micropaleontol., 5:185-203. , in press. Miocene oxygen and carbon isotope stratigraphy of the tropical Indian Ocean. In Kennett, J. P. (Ed.), The Miocene Ocean: Paleoceanography and Biogeography. Geol. Soc. Am. Mem., 163.

Wedepohl, K. H. (Ed.), 1969. Handbook of Geochemistry: New York (Springer-Verlag), p. II-1(6).

Weissert, H. J., McKenzie, J. A., Wright, R. C., Clark, M., Oberhänsli, H., and Casey, M., 1984. Paleoclimatic record of the Pliocene at Deep Sea Drilling Project Sites 519, 521, 522, and 523 (Central South Atlantic). In Hsü, K. J., LaBrecque, J. L., et al., Init. Repts. DSDP, 73: Washington (U.S. Govt. Printing Office), 701-715.

Woodruff, F., and Douglas, R. G., 1981. Response of deep-sea benthic foraminifera to Miocene paleoclimatic events, DSDP Site 289. Mar. Micropaleontol., 6:617-632.

Woodruff, F., and Savin, S. M., 1985. $\delta^{13} \mathrm{C}$ values of Miocene Pacific benthic foraminifera: correlations with sea level and biological productivity. Geology, 13(2):119-122.

Woodruff, F., Savin, S. M., and Douglas, R. G., 1981. Miocene stable isotope record: a detailed deep Pacific Ocean study and its paleoclimatic implications. Science, 212:665-668.

Wyrtki, K., 1974. The Dynamic Topography of the Pacific Ocean and Its Fluctuations. Hawaii Inst. Geophys. Rep. HIG 74-5.

Date of Initial Receipt: 10 May 1985

Date of Acceptance: 17 May 1985

APPENDIX

Oxygen and Carbon Isotope Composition ( $\%_{0}$ PDB) of Benthic and Planktonic Foraminifers, DSDP Sites 588, 590 and $591^{1}$

\begin{tabular}{|c|c|c|c|c|}
\hline \multicolumn{5}{|c|}{ SITE 588} \\
\hline $\begin{array}{c}\text { Core-Section } \\
\text { (interval in cm) }\end{array}$ & $\begin{array}{c}\text { Sub-bottom } \\
\text { depth } \\
(\mathrm{m})\end{array}$ & $\begin{array}{l}\text { Age } \\
(\mathrm{Ma})\end{array}$ & $\begin{array}{l}\delta^{18} \mathrm{O} \\
\quad(\% \mathrm{oo} F\end{array}$ & $\begin{array}{l}\delta^{13} \mathrm{C} \\
\text { DB) } \\
\end{array}$ \\
\hline Hole $588^{\mathrm{a}}$ & & & & \\
\hline $\begin{array}{l}10-1,35-37 \\
10-2,35-37 \\
10-3,35-37 \\
10-4,35-37 \\
10-5,35-37 \\
10-6,35-37 \\
11-1,35-37 \\
11-2,35-37 \\
11-3,35-37 \\
11-4,35-37 \\
11-5,35-37 \\
11-6,35-37 \\
12-1,35-37 \\
12-2,35-37 \\
12-3,35-37 \\
12-4,35-37 \\
12-5,35-37 \\
12-6,35-37 \\
12-7,35-37 \\
13-1,35-37 \\
13-2,35-37 \\
13-3,35-37 \\
13-4,110-111 \\
13-5,110-111 \\
13-6,35-37 \\
13-7,35-37\end{array}$ & $\begin{array}{r}82.8 \\
84.3 \\
85.8 \\
87.3 \\
88.8 \\
90.3 \\
92.4 \\
93.9 \\
95.4 \\
96.9 \\
98.4 \\
99.9 \\
101.9 \\
103.4 \\
104.9 \\
106.4 \\
107.9 \\
109.4 \\
110.9 \\
111.6 \\
113.1 \\
114.6 \\
116.8 \\
118.3 \\
119.1 \\
120.6\end{array}$ & $\begin{array}{l}4.34 \\
4.38 \\
4.42 \\
4.46 \\
4.50 \\
4.54 \\
4.60 \\
4.70 \\
4.79 \\
4.88 \\
4.98 \\
5.07 \\
5.12 \\
5.16 \\
5.20 \\
5.23 \\
5.25 \\
5.28 \\
5.30 \\
5.32 \\
5.34 \\
5.37 \\
5.41 \\
5.43 \\
5.45 \\
5.47\end{array}$ & $\begin{array}{l}1.97 \\
2.07 \\
1.93 \\
1.82 \\
1.99 \\
1.90 \\
1.71 \\
1.86 \\
1.91 \\
2.13 \\
2.06 \\
1.97 \\
1.88 \\
2.03 \\
2.13 \\
2.07 \\
2.04 \\
2.04 \\
2.06 \\
2.47 \\
2.28 \\
2.25 \\
2.04 \\
1.79 \\
2.09 \\
2.29\end{array}$ & $\begin{array}{l}0.75 \\
0.81 \\
0.70 \\
0.88 \\
0.83 \\
0.64 \\
0.84 \\
0.85 \\
0.92 \\
0.84 \\
1.04 \\
0.63 \\
0.90 \\
0.81 \\
0.83 \\
0.96 \\
0.98 \\
0.90 \\
1.12 \\
0.73 \\
0.63 \\
0.65 \\
0.69 \\
0.62 \\
0.79 \\
0.56\end{array}$ \\
\hline
\end{tabular}

${ }^{1}$ Stable isotopic data for Oridorsalis umbonatus (Hole 591B) have been adjusted to that of Cibicidoides by adding $+1.06 \%$ for ${ }^{13} \mathrm{C}$ and subtracting 0.72 for $\delta^{18} \mathrm{O}$ (see text for discussion).

\begin{tabular}{|c|c|c|c|}
\hline $\begin{array}{l}\text { Core-Section } \\
\text { (interval in } \mathrm{cm} \text { ) }\end{array}$ & $\begin{array}{l}\text { Sub-bottom } \\
\text { depth } \\
\text { (m) }\end{array}$ & & $\begin{array}{c}\delta^{18} \mathrm{O} \quad \delta^{13} \mathrm{C} \\
(\% \text { \% } \\
\left.{ }^{13}\right)\end{array}$ \\
\hline
\end{tabular}

\section{Hole 588 (Cont.)}

14-1, 35-37

$14-2,35-37$

$14-3,35-37$

$14-4,35-37$

$14-5,35-37$

14-6, 35-37

14-7, 35-37

$15-1,35-37$

15-2, 35-37

$15-3,35-37$

$15-4,35-37$

$15-5,35-37$

15-6, 35-37

16-1, 35-37

$16-2,35-37$

16-3, 35-37

$16-4,35-37$

$17-1,35-37$

$17-2,35-37$

$17-3,35-37$

$17-4,35-37$

$17-5,35-37$

17-6, 35-37

17-7, 35-37

$18-1,35-37$

$18-2,35-37$

$18-3,35-37$

$18-4,35-37$

$18-5,35-37$

18-6, 35-37

$19-1,50-51$

19-2, 35-37

$19-3,35-37$

$19-4,35-37$

19-5, 35-37

19-6, 35-37

19-7, 35-37

20-2, 35-37

$20-3,35-37$

$20-4,35-37$

20-6, 35-37

$20-7,35-37$

$21-1,35-37$

$21-2,35-37$

$21-3,35-37$

$21-4,35-37$

$21-5,35-37$

$21-6,35-37$

$21-7,35-37$

$22-1,35-37$

22-2, 35-37

$22-3,35-37$

$22-4,35-37$

$22-5,35-37$

22-6, 35-37

$22-7,35-37$

23-1, 35-37

23-2, 35-37

$23-3,35-37$

$23-4,35-27$

$23-5,35-37$

23-6, $35-37$

23-7, $35-37$

24-1, 35-37

24-2, 35-37

$24-3,35-37$

$24-4,35-37$

24-5, 35-37

24-6, 35-37

24-7, 35-37

$25-1,35-37$

$25-2,35-37$

$25-3,35-37$

$25-4,35-37$

$25-5,35-37$

$25-6,35-37$

$25-7,35-37$

121.1

122.6

124.1

125.6

127.1
128.6

128.6
130.1

130.8

130.8
132.3

133.8

135.3

136.8

138.3

140.4

141.9

143.4

144.9

150.0

151.5

153.0

154.5

156.0

157.5

159.0

160.0

161.0

162.5

164.0

165.5

167.0

169.3

172.1

173.6

175.1

176.6

178.1

179.6

180.3

181.8

183.3

186.3

187.8

188.4

189.9

191.4

192.9

194.4

195.9

197.4

198.0

199.5

201.0

202.5

204.0

205.0

207.0

207.5

209.5

210.5

212.0

213.5

215.0

216.5

217.1

218.6

220.1

221.6

223.1

224.6

226.1

226.8

228.3

229.8

231.3

232.8

234.3

235.8

$\begin{array}{lll}5.48 & 2.29 & 1.07\end{array}$

$\begin{array}{lll}5.51 & 2.25 & 1.10\end{array}$

$\begin{array}{lll}5.53 & 2.11 & 0.75 \\ 5.56 & 1.86 & 0.90\end{array}$

$\begin{array}{lll}5.58 & 1.96 & 0.82\end{array}$

$\begin{array}{lll}5.61 & 2.07 & 0.93\end{array}$

$\begin{array}{lll}5.64 & 1.99 & 0.74\end{array}$

$\begin{array}{lll}5.65 & 1.97 & 0.75\end{array}$

$\begin{array}{lll}5.67 & 1.94 & 0.85\end{array}$

$\begin{array}{lll}5.70 & 2.05 & 0.40\end{array}$

$\begin{array}{lll}5.73 & 2.03 & 0.77\end{array}$

$\begin{array}{lll}5.75 & 2.03 & 0.83\end{array}$

$\begin{array}{lll}5.78 & 1.99 & 0.81\end{array}$

$\begin{array}{lll}5.81 & 1.91 & 0.82\end{array}$

$\begin{array}{lll}5.84 & 2.00 & 0.81 \\ 5.87 & 2.09 & 0.67\end{array}$

$\begin{array}{lll}5.87 & 2.09 & 0.67 \\ 5.89 & 2.03 & 0.60\end{array}$

$\begin{array}{lll}5.98 & 2.01 & 0.55\end{array}$

$\begin{array}{lll}6.01 & 2.04 & 0.91\end{array}$

$\begin{array}{lll}6.03 & 2.02 & 0.74\end{array}$

$\begin{array}{lll}6.03 & 1.89 & 0.62 \\ 6.08 & 1.78 & 0.82\end{array}$

$\begin{array}{lll}6.11 & 1.86 & 1.00\end{array}$

$\begin{array}{lll}6.14 & 2.05 & 0.78\end{array}$

$\begin{array}{lll}6.15 & 2.05 & 1.02\end{array}$

$\begin{array}{lll}6.17 & 1.88 & 1.00\end{array}$

$\begin{array}{lll}6.20 & 1.77 & 1.05\end{array}$

$\begin{array}{lll}6.22 & 1.73 & 1.06\end{array}$

$\begin{array}{lll}6.25 & 1.84 & 1.18 \\ 6.50 & 1.75 & 1.19\end{array}$

$\begin{array}{lll}6.88 & 1.81 & 1.24\end{array}$

$\begin{array}{lll}7.36 & 1.85 & 1.20\end{array}$

$\begin{array}{lll}7.61 & 1.79 & 1.01\end{array}$

$\begin{array}{lll}7.87 & 1.89 & 1.23 \\ 8.12 & 2.01 & 1.42\end{array}$

$\begin{array}{lll}8.37 & 2.03 & 1.42\end{array}$

$\begin{array}{lll}8.63 & 2.16 & 1.45\end{array}$

$\begin{array}{lll}8.75 & 2.13 & 1.30\end{array}$

$\begin{array}{lll}9.00 & 1.91 & 0.94\end{array}$

$\begin{array}{lll}9.25 & 1.89 & 1.02\end{array}$

$\begin{array}{lll}9.57 & 1.85 & 1.20\end{array}$

$\begin{array}{lll}9.64 & 1.74 & 1.17\end{array}$

$\begin{array}{lll}9.67 & 1.81 & 1.43\end{array}$

$\begin{array}{lll}9.74 & 1.85 & 1.18 \\ 9.81 & 2.20 & 1.12\end{array}$

$\begin{array}{lll}9.88 & 2.15 & 1.31\end{array}$

$\begin{array}{lll}9.96 & 2.26 & 1.39\end{array}$

$\begin{array}{lll}10.03 & 2.07 & 1.49\end{array}$

$\begin{array}{lll}10.10 & 2.09 & 1.21\end{array}$

$\begin{array}{lll}10.13 & 2.26 & 1.35\end{array}$

$\begin{array}{lll}10.20 & 2.19 & 1.49\end{array}$

$\begin{array}{lll}10.27 & 2.15 & 1.41\end{array}$

$\begin{array}{lll}10.34 & 2.21 & 1.42\end{array}$

$\begin{array}{lll}10.41 & 1.99 & 1.09\end{array}$

$\begin{array}{lll}10.48 & 2.07 & 1.10\end{array}$

$\begin{array}{lll}10.55 & 2.26 & 1.18\end{array}$

$\begin{array}{lll}10.57 & 2.40 & 1.08\end{array}$

$\begin{array}{lll}10.67 & 2.15 & 1.09\end{array}$

$\begin{array}{lll}10.71 & 2.18 & 1.00\end{array}$

$\begin{array}{lll}10.79 & 2.08 & 0.88\end{array}$

$\begin{array}{lll}10.86 & 1.96 & 0.72\end{array}$

$\begin{array}{lll}10.93 & 1.79 & 0.78\end{array}$

$\begin{array}{lll}11.00 & 1.78 & 0.75\end{array}$

$\begin{array}{lll}11.04 & 1.82 & 0.80\end{array}$

$\begin{array}{lll}11.14 & 1.79 & 0.77\end{array}$

$\begin{array}{lll}11.24 & 1.62 & 0.92\end{array}$

$\begin{array}{lll}11.34 & 1.99 & 1.13\end{array}$

$\begin{array}{lll}11.45 & 2.13 & 1.21\end{array}$

$\begin{array}{lll}11.55 & 1.91 & 1.18\end{array}$

$\begin{array}{lll}11.65 & 1.89 & 1.34\end{array}$

$\begin{array}{lll}11.70 & 2.05 & 1.32\end{array}$

$\begin{array}{lll}11.80 & 1.94 & 1.16\end{array}$

$\begin{array}{lll}11.90 & 1.91 & 1.18\end{array}$

$\begin{array}{lll}12.00 & 1.75 & 1.10\end{array}$

$\begin{array}{lll}12.04 & 1.61 & 0.85\end{array}$

$\begin{array}{lll}12.08 & 1.99 & 1.07\end{array}$

$\begin{array}{lll}12.11 & 1.91 & 1.26\end{array}$ 
MIOCENE TO PLIOCENE ISOTOPE STRATIGRAPHY, SOUTHWEST PACIFIC

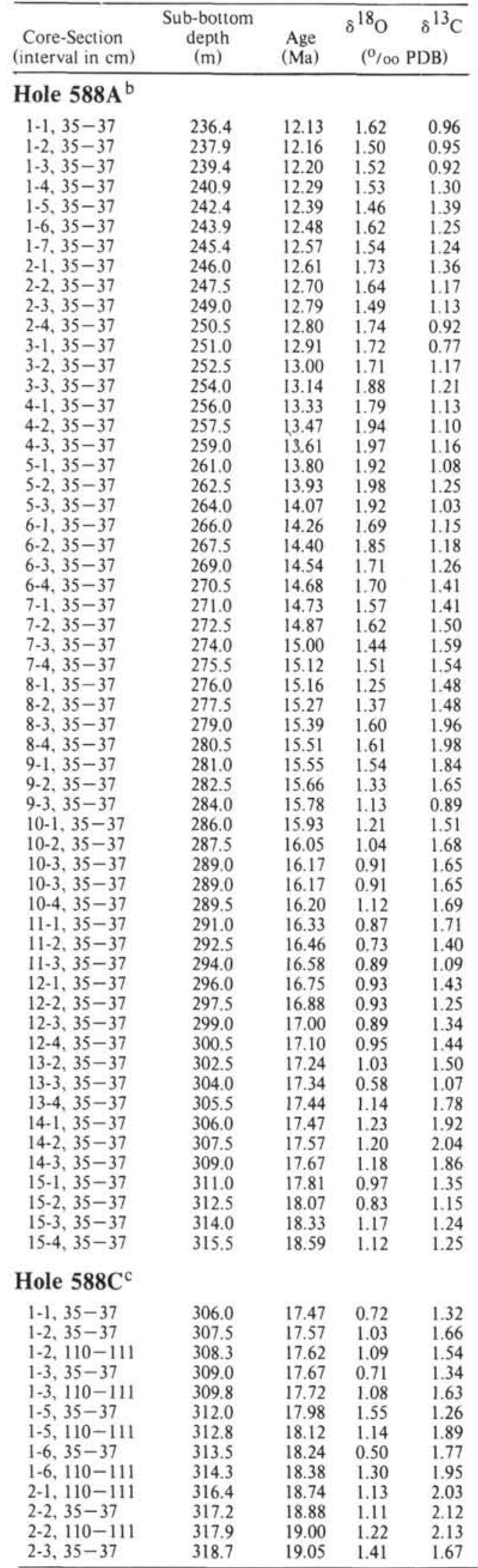

${ }^{\mathrm{b}}$ Samples $588 \mathrm{~A}-1-1,35-37 \mathrm{~cm}$ to $588 \mathrm{~A}-10-4,35-37$ $\mathrm{cm}$, C. kullenbergi; Samples 588A-11-3, 35-37 $\mathrm{cm}$ and $588 \mathrm{~A}-11-2,35-37 \mathrm{~cm}, C$. wuellerstorfi; Samples $588 \mathrm{~A}-1$. $3,35-37 \mathrm{~cm}$ to $588 \mathrm{~A}-15-4,35-37 \mathrm{~cm}$, C. coryelli.

${ }^{\mathrm{c}}$ All samples, $C$, coryelli.

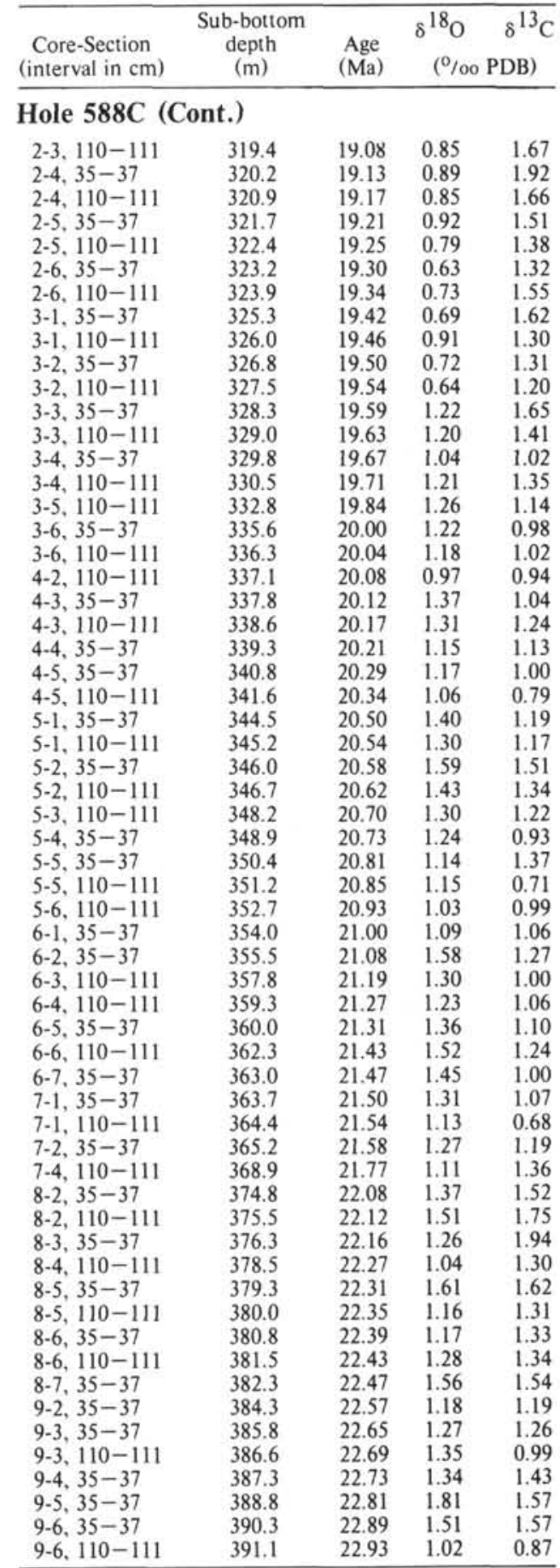

\section{SITE 590}

\begin{tabular}{|c|c|c|c|c|c|c|}
\hline \multirow{2}{*}{$\begin{array}{l}\text { Core-Section } \\
\text { (interval in } \mathrm{cm} \text { ) }\end{array}$} & \multirow{2}{*}{$\begin{array}{l}\text { Sub-bottom } \\
\text { depth } \\
\text { (m) }\end{array}$} & \multirow{2}{*}{$\begin{array}{l}\text { Age } \\
\text { (Ma) }\end{array}$} & \multicolumn{2}{|c|}{$\begin{array}{c}\text { Benthic } \\
(\% \% \text { PDB })\end{array}$} & \multicolumn{2}{|c|}{$\begin{array}{c}\text { Planktonic } \\
\text { ( } \% \text { oo PDB) }\end{array}$} \\
\hline & & & $\delta^{18} \mathrm{O}$ & $\delta^{13} \mathrm{C}$ & $\delta^{18} \mathrm{O}$ & ${ }^{13} \mathrm{C}$ \\
\hline \multicolumn{7}{|l|}{ Hole $590 \mathrm{~A}^{\mathrm{a}}$} \\
\hline $\begin{array}{l}1-6,35-37 \\
2-1,35-37 \\
2-3,35-37\end{array}$ & $\begin{array}{l}34.1 \\
36.2 \\
39.2\end{array}$ & $\begin{array}{l}1.81 \\
1.90 \\
2.02\end{array}$ & $\begin{array}{l}2.59 \\
2.46 \\
2.63\end{array}$ & $\begin{array}{l}0.74 \\
0.85 \\
0.64\end{array}$ & $\begin{array}{l}-0.35 \\
-0.45 \\
-0.49\end{array}$ & $\begin{array}{l}1.90 \\
0.95 \\
1.42\end{array}$ \\
\hline
\end{tabular}

${ }^{\mathrm{a}}$ All benthic results measured using C. kullenbergi; all planktonic results, Globigerinoides sacculifer. 


\begin{tabular}{|c|c|c|c|c|c|c|}
\hline \multirow{2}{*}{$\begin{array}{l}\text { Core-Section } \\
\text { (interval in } \mathrm{cm} \text { ) }\end{array}$} & \multirow{2}{*}{$\begin{array}{l}\text { Sub-bottom } \\
\text { depth } \\
\text { (m) }\end{array}$} & \multirow{2}{*}{$\begin{array}{l}\text { Age } \\
(\mathrm{Ma})\end{array}$} & \multicolumn{2}{|c|}{$\begin{array}{c}\text { Benthic } \\
(\% \% \text { PDB })\end{array}$} & \multicolumn{2}{|c|}{$\begin{array}{l}\text { Planktonic } \\
(\% / \text { oo PDB })\end{array}$} \\
\hline & & & $\delta^{18} \mathrm{O}$ & $\delta^{13} \mathrm{C}$ & $\delta^{18} \mathrm{O}$ & $\delta^{13} \mathrm{C}$ \\
\hline \multicolumn{7}{|c|}{ Hole 590A (Cont.) } \\
\hline $2-5,35-37$ & 42.2 & 2.15 & 2.57 & 0.75 & -0.45 & 1.50 \\
\hline $2-6,35-37$ & 43.7 & 2.21 & 2.52 & 0.94 & -0.69 & 1.58 \\
\hline $3-1,35-37$ & 45.8 & 2.30 & 3.00 & 0.44 & -0.57 & 1.57 \\
\hline $3-2,35-37$ & 47.3 & 2.33 & 2.51 & 0.79 & -0.72 & 1.66 \\
\hline $3-3,35-37$ & 48.8 & 2.37 & -. & .. & -0.09 & 1.39 \\
\hline $3-4,35-37$ & 50.3 & 2.40 & 2.60 & 0.61 & 0.11 & 1.42 \\
\hline $3-5,35-37$ & 51.8 & 2.44 & $\ldots$ & .. & -0.55 & 1.55 \\
\hline $3-6,35-37$ & 53.3 & 2.48 & 2.39 & 0.73 & -0.50 & 1.67 \\
\hline $4-1,35-37$ & 55.3 & 2.53 & 2.38 & 0.78 & -0.56 & 1.52 \\
\hline $4-2,35-37$ & 56.8 & 2.57 & 2.29 & 0.73 & -0.55 & 1.74 \\
\hline $4-3,35-37$ & 58.3 & 2.61 & 2.41 & 0.65 & -0.60 & 1.24 \\
\hline $4-4,35-37$ & 59.8 & 2.65 & 2.34 & 0.85 & -0.70 & 1.57 \\
\hline $4-5,35-37$ & 61.3 & 2.69 & 2.29 & 0.56 & -0.48 & 1.44 \\
\hline $4-6,35-37$ & 62.8 & 2.73 & 1.97 & 0.70 & -0.52 & 1.36 \\
\hline $5-1,110-112$ & 64.9 & 2.79 & 2.25 & 0.98 & -0.77 & 1.39 \\
\hline $5-3,110-112$ & 67.9 & 2.86 & 2.25 & 0.81 & -0.31 & 1.56 \\
\hline $5-5,110-112$ & 70.9 & 2.94 & 1.98 & 0.74 & -0.96 & 1.49 \\
\hline $6-1,55-57$ & 74.6 & 3.04 & 1.98 & 0.83 & -0.60 & 1.59 \\
\hline $6-3,55-57$ & 77.6 & 3.12 & 2.17 & 0.76 & -0.98 & 1.50 \\
\hline $6-5,55-57$ & 80.6 & 3.20 & 1.87 & 0.88 & -0.58 & 1.75 \\
\hline $7-1,35-37$ & 84.1 & 3.29 & 2.15 & 0.93 & -0.67 & 1.58 \\
\hline $7-3,35-37$ & 87.1 & 3.37 & $\ldots$ & .. & -0.39 & 1.45 \\
\hline $7-5,35-37$ & 90.1 & 3.45 & 2.01 & 0.87 & -0.63 & 1.72 \\
\hline $8-1,103-104$ & 93.8 & 3.47 & 2.22 & 0.59 & -0.28 & 1.74 \\
\hline $8-3,35-37$ & 96.8 & 3.48 & -. & -. & -0.35 & 1.34 \\
\hline $8-5,35-37$ & 99.8 & 3.49 & 2.04 & 0.99 & -0.78 & 1.59 \\
\hline $8-6,35-37$ & 101.3 & 3.50 & 2.11 & 0.80 & -0.90 & 1.55 \\
\hline $10-1,35-37$ & 112.9 & 3.55 & 1.98 & 0.73 & -0.74 & 1.37 \\
\hline $10-3,35-37$ & 115.9 & 3.56 & 1.93 & 0.69 & -0.85 & 1.47 \\
\hline $10-5,35-37$ & 118.9 & 3.58 & 1.91 & 0.76 & -0.73 & 1.64 \\
\hline $11-1,35-37$ & 122.6 & 3.59 & 1.89 & 0.91 & -0.46 & 1.48 \\
\hline $11-3,35-37$ & 125.6 & 3.61 & $\ldots$ & .. & -0.45 & 1.39 \\
\hline $11-4,35-37$ & 127.1 & 3.61 & 1.92 & 0.87 & -0.68 & 1.73 \\
\hline $11-6,35-37$ & 130.0 & 3.63 & $\ldots$ & -. & -0.85 & 1.37 \\
\hline $12-1,35-37$ & 132.1 & 3.64 & 1.84 & 0.87 & -0.59 & 1.57 \\
\hline $12-3,35-37$ & 135.1 & 3.65 & 1.64 & 0.75 & -0.31 & 1.53 \\
\hline $12-5,35-37$ & 138.1 & 3.70 & .. & -. & -0.54 & 1.71 \\
\hline $12-6,35-37$ & 139.6 & 3.73 & 1.88 & 1.06 & -0.66 & 1.47 \\
\hline $13-1,35-37$ & 141.8 & 3.77 & 1.78 & 0.94 & -0.22 & 1.68 \\
\hline $13-3,35-37$ & 144.8 & 3.82 & 1.87 & 0.86 & -0.32 & 1.52 \\
\hline $13-5,35-37$ & 147.8 & 3.87 & .. & .. & -0.23 & 1.70 \\
\hline $13-6,35-37$ & 149.3 & 3.90 & 1.80 & 0.87 & -0.20 & 1.32 \\
\hline $14-1,35-37$ & 151.4 & 3.93 & .. & .. & -0.31 & 1.54 \\
\hline $14-2,35-37$ & 152.9 & 3.96 & .. & .. & -0.38 & 1.53 \\
\hline $14-3,35-37$ & 154.4 & 3.99 & 1.81 & 0.77 & -0.36 & 1.08 \\
\hline $14-4,35-37$ & 155.9 & 4.01 & .. & .. & -0.53 & 1.12 \\
\hline $14-5,35-37$ & 157.4 & 4.04 & 1.76 & 0.68 & -0.66 & 0.83 \\
\hline $14-6,35-37$ & 158.9 & 4.06 & $\ldots$ & .. & -0.26 & 1.45 \\
\hline $15-1,35-37$ & 161.0 & 4.10 & 1.76 & 0.93 & -0.29 & 1.58 \\
\hline $15-2,35-37$ & 162.5 & 4.14 & $\ldots$ & .. & -0.45 & 1.46 \\
\hline $15-3,35-37$ & 164.0 & 4.18 & 1.95 & 0.63 & -0.26 & 1.51 \\
\hline $15-4,35-37$ & 165.5 & 4.22 & $\ldots$ & .. & -0.29 & 1.35 \\
\hline $15-5,35-37$ & 167.0 & 4.26 & 1.73 & 1.01 & -0.16 & 1.59 \\
\hline $15-6,35-37$ & 168.5 & 4.30 & $\ldots$ & .. & -0.11 & 1.58 \\
\hline $16-1,35-37$ & 170.6 & 4.35 & 1.80 & 0.96 & -0.31 & 1.75 \\
\hline $16-2,35-37$ & 172.1 & 4.39 & 1.92 & 1.00 & -0.35 & 1.76 \\
\hline $16-3,35-37$ & 173.6 & 4.43 & 1.85 & 1.03 & -0.49 & 1.79 \\
\hline $16-4,35-37$ & 175.1 & 4.47 & .. & .. & -0.22 & 1.88 \\
\hline $16-5,35-37$ & 176.6 & 4.51 & 1.75 & 0.82 & -0.35 & 1.31 \\
\hline $17-1,35-37$ & 180.1 & 4.60 & 1.97 & 1.15 & -0.73 & 1.85 \\
\hline $17-2,35-37$ & 183.1 & 4.70 & .. & .. & -0.80 & 1.67 \\
\hline $17-3,121-122$ & 184.0 & 4.73 & .. & .. & 2.17 & 0.72 \\
\hline $17-5,35-37$ & 186.1 & 4.80 & 2.13 & 0.86 & -0.31 & 1.43 \\
\hline $18-1,35-37$ & 189.9 & 4.92 & 1.93 & 1.09 & -0.59 & 2.01 \\
\hline $18-2,35-37$ & 191.3 & 4.97 & 1.91 & 1.10 & -0.62 & 2.06 \\
\hline $18-4,35-37$ & 194.3 & 5.07 & 1.84 & 0.78 & -0.31 & 1.85 \\
\hline $18-5,35-37$ & 195.8 & 5.12 & 1.79 & 0.88 & -0.49 & 1.83 \\
\hline $18-6,35-37$ & 197.3 & 5.17 & 1.97 & 0.47 & -0.13 & 1.47 \\
\hline $19-1,35-36$ & 199.4 & 5.22 & 2.03 & 0.68 & -0.60 & 1.63 \\
\hline $19-2,35-37$ & 200.9 & 5.24 & 1.83 & 0.84 & -0.55 & 1.93 \\
\hline $19-3,35-37$ & 202.4 & 5.26 & 1.97 & 0.69 & -0.37 & 1.65 \\
\hline $19-4,35-37$ & 203.9 & 5.28 & 2.10 & 0.59 & -0.75 & 1.54 \\
\hline $19-5,35-37$ & 205.4 & 5.30 & 1.86 & 0.88 & -0.76 & 1.78 \\
\hline $19-6,35-37$ & 206.9 & 5.32 & 1.83 & 0.70 & -0.67 & 2.01 \\
\hline $20-1,35-37$ & 209.0 & 5.35 & 1.94 & 0.51 & -0.45 & 1.28 \\
\hline $20-2,35-37$ & 210.5 & 5.37 & 1.76 & 0.66 & -0.50 & 1.59 \\
\hline $20-4,35-37$ & 213.5 & 5.41 & 1.76 & 0.88 & -0.69 & 2.11 \\
\hline
\end{tabular}

\begin{tabular}{|c|c|c|c|c|c|c|}
\hline \multirow{2}{*}{$\begin{array}{l}\text { Core-Section } \\
\text { (interval in } \mathrm{cm} \text { ) }\end{array}$} & \multirow{2}{*}{$\begin{array}{l}\text { Sub-bottom } \\
\text { depth } \\
\text { (m) }\end{array}$} & \multirow{2}{*}{$\begin{array}{l}\text { Age } \\
(\mathrm{Ma})\end{array}$} & \multicolumn{2}{|c|}{$\begin{array}{c}\text { Benthic } \\
(\% \% \text { PDB })\end{array}$} & \multicolumn{2}{|c|}{$\begin{array}{l}\text { Planktonic } \\
\text { (\% \% PDB) }\end{array}$} \\
\hline & & & $\delta^{18} \mathrm{O}$ & $\delta^{13} \mathrm{C}$ & $\delta^{18} \mathrm{O}$ & $\delta^{13} \mathrm{C}$ \\
\hline \multicolumn{7}{|c|}{ Hole 590A (Cont.) } \\
\hline $20-6,35-37$ & 216.5 & 5.45 & 1.67 & 0.65 & -0.45 & 1.59 \\
\hline $21-1,35-37$ & 218.6 & 5.48 & 1.61 & 0.80 & -0.80 & 1.84 \\
\hline $21-3,35-37$ & 221.6 & 5.52 & 1.81 & 0.50 & -0.64 & 1.59 \\
\hline $21-5,35-37$ & 224.6 & 5.56 & 1.80 & 0.93 & -0.44 & 1.97 \\
\hline $21-7,35-37$ & 227.6 & 5.60 & 1.84 & 0.71 & -0.45 & 1.76 \\
\hline $22-2,35-37$ & 229.7 & 5.63 & 1.77 & 0.67 & -0.55 & 2.01 \\
\hline $23-1,35-37$ & 237.8 & 5.74 & 1.87 & 0.69 & -0.47 & 1.73 \\
\hline $23-3,35-37$ & 240.8 & 5.78 & 1.90 & 0.75 & -0.50 & 1.68 \\
\hline $23-5,35-37$ & 244.6 & 5.83 & 1.85 & 0.70 & -0.72 & 1.57 \\
\hline $24-1,35-37$ & 247.4 & 5.87 & 1.96 & 0.48 & -0.60 & 1.26 \\
\hline $24-3,35-37$ & 250.4 & 5.91 & 1.84 & 0.45 & -0.38 & 1.24 \\
\hline $24-5,35-37$ & 253.4 & 5.96 & 1.87 & 0.46 & -0.38 & 1.62 \\
\hline $24-6,35-37$ & 254.9 & 5.98 & 1.64 & 0.60 & -0.32 & 1.85 \\
\hline $24-7,35-37$ & 256.4 & 6.00 & 1.80 & 0.54 & -0.40 & 1.56 \\
\hline $25-1,121-122$ & 257.0 & 6.00 & 2.02 & 0.69 & -0.13 & 1.92 \\
\hline
\end{tabular}

Hole 590 ${ }^{\text {b }}$

\begin{tabular}{|c|c|c|c|c|c|c|}
\hline $28-6,35-37$ & 258.5 & 6.02 & .. & .. & -0.39 & 2.00 \\
\hline $29-1,35-37$ & 259.5 & 6.04 & -. & ... & -0.29 & 1.94 \\
\hline $29-2,35-37$ & 261.5 & 6.07 & 1.80 & 0.77 & -0.33 & 1.59 \\
\hline $29-3,35-37$ & 262.5 & 6.08 & -. & -. & -0.26 & 1.78 \\
\hline $29-4,35-37$ & 264.0 & 6.10 & .. & -. & -0.55 & 2.13 \\
\hline $29-5,35-37$ & 265.5 & 6.12 & - & $\ddot{-}$ & -0.20 & 1.87 \\
\hline $29-6,35-37$ & 267.4 & 6.15 & 1.71 & 0.79 & -0.70 & 2.16 \\
\hline $30-1,35-37$ & 269.0 & 6.17 & .. &.- & -0.19 & 2.09 \\
\hline $30-2,35-37$ & 270.0 & 6.18 & 1.90 & 0.70 & -0.36 & 2.30 \\
\hline $30-3,35-37$ & 272.0 & 6.21 & .. & .. & -0.30 & 2.14 \\
\hline $30-4,35-37$ & 273.5 & 6.23 & -. & .. & -0.53 & 2.12 \\
\hline $30-5,35-37$ & 275.0 & 6.25 &.. & - & -0.47 & 2.20 \\
\hline $30-6,35-37$ & 276.2 & 6.32 & 1.85 & 0.82 & -0.43 & 2.07 \\
\hline $31-1,35-38$ & 278.7 & 6.48 & $\ddot{z}$ & .. & -0.56 & 2.11 \\
\hline $31-2,35-37$ & 280.7 & 6.60 & 1.76 & 1.02 & -0.61 & 2.24 \\
\hline $31-3,35-37$ & 281.7 & 6.66 & 1.73 & 1.11 & -0.71 & 2.15 \\
\hline $31-4,35-37$ & 283.2 & 6.75 & 1.78 & 0.93 & -0.43 & 2.11 \\
\hline $31-5,35-37$ & 284.7 & 6.84 & 1.86 & 1.10 & -0.65 & 2.15 \\
\hline $32-1,35-37$ & 288.3 & 7.06 & 1.69 & 1.06 & -0.62 & 2.18 \\
\hline $32-2,35-37$ & 289.8 & 7.15 & 1.65 & 1.12 & -0.34 & 2.23 \\
\hline $32-3,35-37$ & 291.3 & 7.25 & 1.88 & 0.93 & -0.64 & 2.27 \\
\hline $32-4,35-37$ & 292.8 & 7.34 & 1.77 & 0.98 & -0.49 & 2.13 \\
\hline $32-5,35-37$ & 294.3 & 7.43 & 1.66 & 1.02 & -0.60 & 2.49 \\
\hline $32-6,35-37$ & 295.8 & 7.52 & 1.81 & 0.97 & -0.69 & 2.35 \\
\hline $33-1,35-37$ & 297.8 & 7.64 & 1.63 & 1.26 & -0.69 & 2.48 \\
\hline $33-2,35-37$ & 299.3 & 7.73 & 1.66 & 1.19 & -0.67 & 2.14 \\
\hline $33-3,35-37$ & 300.8 & 7.83 & 1.49 & 1.28 & -0.48 & 2.54 \\
\hline $33-4,35-37$ & 301.3 & 7.86 & 1.46 & 1.29 & -0.62 & 2.67 \\
\hline $33-5,35-37$ & 302.8 & 7.95 & 1.55 & 1.37 & -0.74 & 2.57 \\
\hline $33-6,35-37$ & 304.3 & 8.04 & 1.71 & 1.32 & -0.25 & 2.56 \\
\hline $33-7,35-37$ & 305.8 & 8.13 & 1.42 & 1.00 & -0.38 & 2.07 \\
\hline $34-1,35-37$ & 307.5 & 8.24 & 1.69 & 1.15 & -0.71 & 2.00 \\
\hline $34-2,35-37$ & 309.0 & 8.33 & 1.70 & 1.18 & -0.35 & 2.04 \\
\hline $34-3,35-37$ & 310.5 & 8.42 & 1.85 & 1.17 & -0.56 & 2.02 \\
\hline $34-4,35-37$ & 312.0 & 8.51 & 1.78 & 1.33 & -0.62 & 2.29 \\
\hline $34-5,35-37$ & 313.5 & 8.60 & 1.82 & 1.24 & -0.48 & 2.05 \\
\hline $34-6,35-37$ & 315.0 & 8.69 & 1.58 & 0.93 & -0.22 & 1.95 \\
\hline $34, \mathrm{CC}$ & 316.6 & 8.79 & 1.68 & 1.00 & -0.17 & 2.20 \\
\hline $35-1,35-37$ & 317.0 & 8.82 & 1.82 & 1.14 & -0.61 & 1.93 \\
\hline $35-2,35-37$ & 318.5 & 8.91 & 1.99 & 1.14 & -0.69 & 1.94 \\
\hline $35-3,35-37$ & 320.0 & 9.00 & 1.81 & 1.38 & -0.43 & 1.50 \\
\hline $35-4,35-37$ & 321.5 & 9.09 & 1.92 & 1.43 & -0.27 & 2.27 \\
\hline $35-5,35-37$ & 323.0 & 9.18 & 1.85 & 1.43 & -0.20 & 2.25 \\
\hline $36-1,35-37$ & 326.7 & 9.41 & 1.98 & 1.37 & -0.53 & 2.29 \\
\hline $36-2,35-37$ & 328.2 & 9.50 & 2.00 & 1.52 & -0.49 & 2.35 \\
\hline $36-3,35-37$ & 329.7 & 9.58 & 1.78 & 1.34 & -0.43 & 2.26 \\
\hline $36-4,35-37$ & 331.2 & 9.66 & 1.59 & 1.19 & -0.32 & 2.22 \\
\hline $36-5,35-37$ & 332.7 & 9.73 & 1.75 & 1.49 & $\cdots$ & 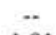 \\
\hline $37-1,35-37$ & 336.3 & 9.92 & 1.54 & 1.01 & -0.70 & 1.91 \\
\hline $37-2,35-37$ & 337.8 & 10.00 & 1.70 & 1.09 & -0.51 & 2.01 \\
\hline $37-3,35-37$ & 339.3 & 10.08 & 1.68 & 1.11 & -0.74 & 2.14 \\
\hline $37-4,35-37$ & 340.8 & 10.16 & 1.71 & 1.04 & -0.43 & 1.83 \\
\hline $37-5,35-37$ & 342.3 & 10.23 & 1.75 & 1.01 & -0.37 & 1.95 \\
\hline $37-6,35-37$ & 343.8 & 10.31 & 1.93 & 1.12 & -0.52 & 2.20 \\
\hline $38-1,35-37$ & 345.9 & 10.42 & 1.40 & 0.76 & -0.51 & 1.85 \\
\hline $38-2,35-37$ & 347.4 & 10.50 & 1.50 & 0.98 & -0.44 & 1.90 \\
\hline
\end{tabular}

${ }^{b}$ All benthic results measured using $C$. kullenbergi except for samples marked with asterisk, where $C$. coryelli was measured. All planktonic results, Globigerinoides quadrilobatus. 


\begin{tabular}{|c|c|c|c|c|c|c|}
\hline \multirow{2}{*}{$\begin{array}{l}\text { Core-Section } \\
\text { (interval in } \mathrm{cm} \text { ) }\end{array}$} & \multirow{2}{*}{$\begin{array}{l}\text { Sub-bottom } \\
\text { depth } \\
\text { (m) }\end{array}$} & \multirow{2}{*}{$\begin{array}{l}\text { Age } \\
(\mathrm{Ma})\end{array}$} & \multicolumn{2}{|c|}{$\begin{array}{c}\text { Benthic } \\
(\% \text { oo PDB })\end{array}$} & \multicolumn{2}{|c|}{$\begin{array}{l}\text { Planktonic } \\
(\% \text { PDB })\end{array}$} \\
\hline & & & $\delta^{18} \mathrm{O}$ & $\delta^{13} \mathrm{C}$ & $\delta^{18} \mathrm{O}$ & ${ }^{13} \mathrm{C}$ \\
\hline \multicolumn{7}{|c|}{ Hole 590B (Cont.) } \\
\hline $38-3,35-37$ & 348.9 & 10.58 & 1.94 & 0.78 & -0.93 & 1.79 \\
\hline $38-4,35-37$ & 350.4 & 10.66 & 1.43 & 0.52 & -0.80 & 1.88 \\
\hline $38-5,35-37$ & 351.9 & 10.73 & 1.80 & 0.69 & -0.44 & 1.88 \\
\hline $38-6,35-37$ & 353.4 & 10.81 & 1.89 & 0.92 & -0.39 & 1.82 \\
\hline $38-7,35-37$ & 354.9 & 10.89 & 1.31 & 0.76 & .. & .. \\
\hline $39-1,35-37$ & 355.5 & 10.92 & 1.83 & 0.84 & -0.79 & 1.93 \\
\hline $39-2,35-37$ & 357.0 & 11.00 & 1.93 & 0.76 & -0.34 & 1.79 \\
\hline $39-3,35-37$ & 358.5 & 11.08 & 1.59 & 1.19 & -0.71 & 1.72 \\
\hline $39-4,35-37$ & 360.0 & 11.16 & 1.72 & 0.86 & -0.40 & 1.57 \\
\hline $39-5,35-37$ & 361.5 & 11.23 & 1.45 & 0.96 & -0.29 & 1.88 \\
\hline $39-6,35-37$ & 363.0 & 11.31 & 1.94 & 0.85 & -0.80 & 1.50 \\
\hline $41-1,35-37$ & 374.7 & 11.92 & 1.59 & 1.20 & -0.69 & 1.51 \\
\hline $41-2,35-37$ & 376.2 & 12.00 & 1.59 & 1.10 & -0.53 & 1.60 \\
\hline $41-3,35-37$ & 377.7 & 12.03 & 1.51 & 1.20 & -0.83 & 1.62 \\
\hline $41-4,35-37$ & 379.2 & 12.06 & 1.65 & 1.17 & -0.56 & 1.43 \\
\hline $41-5,35-37$ & 380.7 & 12.09 & 1.52 & 1.06 & -0.65 & 1.60 \\
\hline $41-6,35-37$ & 382.2 & 12.13 & 1.14 & 1.13 & -0.57 & 1.67 \\
\hline $42-1,35-37$ & 384.3 & 12.17 & 1.86 & 1.17 & -0.67 & 1.79 \\
\hline $42-2,35-37$ & 385.8 & 12.20 & 1.76 & 1.20 & -0.53 & 1.65 \\
\hline $42-3,35-37$ & 387.3 & 12.24 & 1.83 & 1.40 & -0.55 & 2.03 \\
\hline $42-4,35-37$ & 388.8 & 12.28 & 2.17 & 1.45 & -0.86 & 2.02 \\
\hline $42-5,35-37$ & 390.3 & 12.32 & 1.74 & 1.29 & -0.47 & 1.89 \\
\hline $42-6,35-37$ & 391.8 & 12.36 & 1.96 & 1.24 & -0.82 & 1.77 \\
\hline $43-1,35-37$ & 393.8 & 12.41 & 1.34 & 1.07 & -1.01 & 2.08 \\
\hline $43-2,35-37$ & 395.3 & 12.45 & 1.06 & 0.86 & -0.65 & 1.88 \\
\hline $43-3,35-37$ & 396.8 & 12.49 & 1.22 & 0.88 & -0.21 & $\begin{array}{l}1.60 \\
1.63\end{array}$ \\
\hline $43-4,35-37$ & 398.3 & 12.53 & 0.96 & 0.90 & -0.24 & 1.74 \\
\hline $43-5,35-37$ & 399.8 & 12.57 & 1.38 & 1.07 & -0.42 & 1.98 \\
\hline $44-1,35-37$ & 403.5 & 12.67 & 1.29 & 0.84 & -0.76 & 1.88 \\
\hline $44-2,35-37$ & 405.0 & 12.71 & 1.32 & 0.90 & -0.92 & 2.18 \\
\hline $44-3,35-37$ & 406.5 & 12.75 & 1.29 & 1.01 & -0.54 & 1.96 \\
\hline $44-4,35-37$ & 408.0 & 12.79 & 1.42 & 1.02 & -0.51 & 2.28 \\
\hline $44-5,35-37$ & 409.5 & 12.83 & 1.48 & 1.17 & -0.74 & 2.33 \\
\hline $44-6,35-37$ & 411.0 & 12.87 & 1.50 & 1.13 & -0.47 & 2.52 \\
\hline $45-1,35-37$ & 413.0 & 12.92 & 1.50 & 1.24 & -0.51 & 2.15 \\
\hline $45-2,35-37$ & 414.5 & 12.96 & 1.33 & 1.09 & -1.07 & 2.00 \\
\hline $45-4,35-37$ & 417.5 & 13.13 & 1.66 & 1.18 & -0.89 & 2.21 \\
\hline $45-5,35-37$ & 419.0 & 13.27 & 1.61 & 1.26 & -0.70 & 2.07 \\
\hline $46-1,35-37$ & 422.7 & 13.60 & 1.28 & 1.20 & -0.84 & 2.30 \\
\hline $46-2,35-37$ & 424.5 & 13.74 & 1.18 & 1.31 & -0.73 & 2.16 \\
\hline $46-3,35-37$ & 425.7 & 13.87 & 1.30 & 1.44 & -0.69 & 2.47 \\
\hline $46-4,35-37$ & 427.2 & 14.00 & 1.40 & 1.44 & -0.94 & 2.46 \\
\hline $46-5,35-37$ & 428.7 & 14.14 & 1.42 & 1.44 & -1.03 & 2.37 \\
\hline $46-6,35-37$ & 430.2 & 14.27 & 1.31 & 1.51 & -1.09 & 2.42 \\
\hline $47-1,35-37$ & 423.3 & 14.46 & 0.93 & 1.36 & -0.77 & 2.09 \\
\hline $47-2,35-37$ & 433.8 & 14.60 & 1.23 & 1.75 & -1.30 & 2.47 \\
\hline $47-3,35-37$ & 435.3 & 14.73 & 1.26 & 1.74 & -1.17 & 1.70 \\
\hline $47-4,35-37$ & 436.8 & 14.87 & 1.41 & 2.11 & -0.90 & 2.69 \\
\hline $47-5,35-37$ & 438.3 & 15.00 & 1.34 & 2.11 & -1.24 & 3.08 \\
\hline $47-6,35-37$ & 439.8 & 15.14 & 1.33 & 2.19 & -1.00 & 2.88 \\
\hline $48-1,35-37$ & 441.8 & 15.32 & 0.98 & 1.65 & -1.23 & 2.21 \\
\hline $48-2,35-37$ & 443.3 & 15.45 & 0.93 & 1.57 & -1.03 & 2.20 \\
\hline $48-3,35-37$ & 444.8 & 15.59 & 1.12 & 1.75 & -0.94 & 2.68 \\
\hline $48-4,35-37$ & 446.3 & 15.73 & 1.00 & 1.79 & -1.05 & 2.35 \\
\hline $48-5,35-37$ & 447.8 & 15.86 & 0.97 & 1.74 & -1.18 & 2.58 \\
\hline $48-6,35-37$ & 449.7 & 16.00 & 0.34 & 1.46 & -1.04 & 2.44 \\
\hline $48-7,35-37$ & 450.8 & 16.14 & 0.90 & 1.83 & -0.79 & 2.39 \\
\hline - $49-1,35-37$ & 451.5 & 16.20 & 0.95 & 1.51 & -0.54 & 2.33 \\
\hline $49-1,35-37$ & 451.5 & 16.20 & .. & .. & 0.85 & 1.77 \\
\hline $49-2,35-37$ & 453.0 & 16.34 & 0.82 & 1.66 & -0.75 & 2.42 \\
\hline$\cdot 49-2,35-37$ & 453.0 & 16.34 & 0.96 & 1.20 & .. & .. \\
\hline $49-3,35-37$ & 454.5 & 16.50 & 0.86 & 1.75 & -0.68 & 2.35 \\
\hline * $49-3,35-37$ & 454.5 & 16.50 & 1.00 & 1.36 & .. & .. \\
\hline $49-4,35-37$ & 456.0 & 18.00 & 1.09 & 1.41 & -0.83 & 2.20 \\
\hline $49-4,35-37$ & 456.0 & 18.00 & .. & .. & -0.68 & 1.72 \\
\hline $49-5,35-37$ & 457.5 & 18.06 & 1.27 & 1.52 & -0.75 & 2.37 \\
\hline $49-5,35-37$ & 457.5 & 18.06 & .. & .. & 0.93 & 1.64 \\
\hline$-50-1,35-37$ & 461.0 & 18.19 & 0.84 & 1.24 & -0.51 & 2.15 \\
\hline - $50-3,35-37$ & 464.0 & 18.31 & 0.43 & 1.09 & -1.04 & 2.14 \\
\hline $50-3,35-37$ & 464.0 & 18.31 & .. & .. & 0.78 & 1.35 \\
\hline$* 51-1,35-37$ & 470.7 & 18.57 & 1.11 & 0.89 & -0.56 & 1.72 \\
\hline$\cdot 51-2,35-37$ & 472.2 & 18.63 & 1.15 & 0.79 & -0.55 & 1.87 \\
\hline$-51-3,35-37$ & 474.0 & 18.69 & 0.90 & 0.94 & -0.87 & 1.95 \\
\hline$\cdot 51-4,35-37$ & 475.2 & 18.74 & .. & .. & -0.71 & 1.94 \\
\hline * $51-4,35-37$ & 475.2 & 18.74 & .. & $\ldots$ & 1.10 & 1.08 \\
\hline$-51-5,35-37$ & 476.7 & 18.80 & 1.21 & 1.19 & -0.45 & 1.80 \\
\hline$* 51-6,35-37$ & 478.2 & 18.86 & 1.34 & 1.04 & -0.00 & 1.74 \\
\hline
\end{tabular}

\begin{tabular}{|c|c|c|c|c|c|c|}
\hline \multirow{2}{*}{$\begin{array}{l}\text { Core-Section } \\
\text { (interval in } \mathrm{cm} \text { ) }\end{array}$} & \multirow{2}{*}{$\begin{array}{l}\text { Sub-bottom } \\
\text { depth } \\
\text { (m) }\end{array}$} & \multirow{2}{*}{$\begin{array}{l}\text { Age } \\
(\mathrm{Ma})\end{array}$} & \multicolumn{2}{|c|}{$\begin{array}{c}\text { Benthic } \\
(\% \text { PDB }) \\
\end{array}$} & \multicolumn{2}{|c|}{$\begin{array}{l}\text { Planktonic } \\
(\% / 00 \text { PDB })\end{array}$} \\
\hline & & & $\delta^{18} \mathrm{O}$ & ${ }_{\delta}^{13} \mathrm{C}$ & $\delta^{18} \mathrm{O}$ & ${ }^{13} \mathrm{C}$ \\
\hline \multicolumn{7}{|c|}{ Hole 590B (Cont.) } \\
\hline$\cdot 52-1,35-37$ & 480.3 & & 1.07 & $\begin{array}{l}1.07 \\
0.08\end{array}$ & $\begin{array}{r}-0.97 \\
-0.87\end{array}$ & $\begin{array}{l}1.68 \\
1.74\end{array}$ \\
\hline & & & & & -0.87 & 1.74 \\
\hline$* 5$ & 483 & 19.16 & 1.07 & 0.77 & - & $\ddot{x}$ \\
\hline & & & 1.10 & & -0.41 & 1.5 \\
\hline$-52-5,35-3$ & 486 & 19.48 & 1.10 & 1.32 & -0 . & \\
\hline & & & 1.09 & 1. & & 2.15 \\
\hline - $53-1,35$ - & 489 & 19.8 & 1.28 & 1.3 & -0.92 & 2.34 \\
\hline & & & 1.13 & & & 2.33 \\
\hline$-53-3,35-37$ & 492.8 & 20.1 & 1.30 & 1. & -0 & 1.95 \\
\hline$* 53-4,35-37$ & & & 1.28 & & -0 . & 1.73 \\
\hline$* 53-5,35-$ & & 20. & 0.88 & & -0.52 & 1.97 \\
\hline$* 53-6,35-37$ & 497.4 & 20.67 & 1.20 & 1.20 & -0.39 & 1.8 \\
\hline
\end{tabular}

\begin{tabular}{|c|c|c|c|c|}
\hline \multicolumn{5}{|c|}{ SITE 591} \\
\hline $\begin{array}{l}\text { Core-Section } \\
\text { (interval in } \mathrm{cm} \text { ) }\end{array}$ & $\begin{array}{l}\text { Sub-bottom } \\
\text { depth } \\
\text { (m) }\end{array}$ & $\begin{array}{l}\text { Age } \\
\text { (Ma) }\end{array}$ & $\frac{(\% / 00 \text { PDB })}{\delta^{18} \mathrm{O}}$ & $\frac{\delta^{13} \mathrm{C}}{\left(\frac{\mathrm{oo} \text { PDB }}{\delta^{13} \mathrm{C}}\right.}$ \\
\hline
\end{tabular}

Hole $591^{\text {a }}$

\begin{tabular}{lllll}
$20-1,35-37$ & 174.6 & 3.37 & 2.27 & 0.64 \\
$20-1,128-130$ & 175.6 & 3.45 & 2.11 & 0.80 \\
$20-2.35-37$ & 176.1 & 3.49 & 2.22 & 0.83 \\
$20-2,128-130$ & 177.1 & 3.57 & 2.16 & 0.68 \\
$20-3,35-37$ & 177.6 & 3.61 & 2.13 & 0.73 \\
$20-3,128-130$ & 178.6 & 3.69 & 2.16 & 0.70 \\
$20-4,35-37$ & 179.1 & 3.73 & 2.23 & 0.71 \\
$20-4,128-130$ & 180.1 & 3.81 & 2.30 & 0.92 \\
$20-5,35-37$ & 180.6 & 3.85 & 2.18 & 0.82 \\
$20-5,128-130$ & 181.6 & 3.93 & 2.36 & 0.58 \\
$20-6,35-37$ & 182.1 & 3.97 & 2.04 & 0.58 \\
$20-6,128-130$ & 183.1 & 4.04 & 2.01 & 0.50 \\
$20, C C$ & 183.8 & 4.10 & 2.27 & 0.72 \\
$21-1,35-37$ & 184.1 & 4.12 & 2.17 & 0.76 \\
$21-1,128-130$ & 185.1 & 4.20 & 2.26 & 0.86 \\
$21-2,35-37$ & 185.6 & 4.24 & 2.13 & 0.81 \\
$21-2,128-130$ & 186.6 & 4.32 & 2.29 & 0.73 \\
$21-3,35-37$ & 187.1 & 4.36 & 2.35 & 0.58 \\
$21-3,128-130$ & 188.1 & 4.44 & 2.13 & 0.68 \\
$21-4,35-37$ & 188.6 & 4.48 & 2.79 & 0.28 \\
$21-4,128-130$ & 189.6 & 4.56 & 2.25 & 0.65 \\
$21-5,35-37$ & 190.1 & 4.60 & 2.38 & 0.32 \\
$21-5,128-130$ & 191.1 & 4.66 & 2.26 & 0.67 \\
$21-6,35-37$ & 191.6 & 4.69 & 2.13 & 0.61 \\
$21-6,128-130$ & 192.6 & 4.75 & 2.17 & 0.72 \\
$22-1,35-37$ & 193.6 & 4.81 & 2.24 & 0.79 \\
$22-1,128-130$ & 194.6 & 4.86 & 2.35 & 0.63 \\
$22-2,128-130$ & 196.1 & 4.95 & 2.40 & 0.63 \\
$22-3,35-37$ & 196.6 & 4.98 & 2.20 & 0.88 \\
$22-3,128-130$ & 197.6 & 5.04 & 2.11 & 0.63 \\
$22-4,35-37$ & 198.1 & 5.07 & 2.43 & 0.35 \\
$22-4,128-130$ & 199.1 & 5.08 & 2.47 & 0.63 \\
$22-5,35-37$ & 199.6 & 5.08 & 2.31 & 0.80 \\
$22, C C$ & 202.7 & 5.11 & 2.09 & 0.48 \\
$23-1,35-37$ & 203.0 & 5.12 & 2.30 & 0.43 \\
$23-1,128-130$ & 204.0 & 5.13 & 2.34 & 0.52 \\
$23-2,35-37$ & 204.5 & 5.13 & 2.07 & 0.32 \\
$23-2,128-130$ & 205.5 & 5.14 & 2.17 & 0.26 \\
$23-3,35-37$ & 206.0 & 5.15 & 2.28 & 0.33 \\
$23-3,128-130$ & 207.0 & 5.16 & 2.38 & 0.15 \\
$23-4,35-37$ & 207.5 & 5.16 & 2.10 & 0.58 \\
$23-4,128-130$ & 208.5 & 5.17 & 1.35 & 0.56 \\
$23-5,35-37$ & 209.0 & 5.18 & 2.38 & 0.49 \\
$23-5,128-130$ & 210.0 & 5.19 & 2.33 & 0.63 \\
$23-6,35-37$ & 210.5 & 5.19 & 2.26 & 0.73 \\
$23-6,128-130$ & 211.5 & 5.20 & 2.53 & 0.37 \\
$23, C C$ & 212.1 & 5.22 & 2.24 & 0.49 \\
$24-1,35-37$ & 212.5 & 5.23 & 2.40 & 0.56 \\
$24-1,128-130$ & 213.4 & 5.25 & 2.40 & 0.69 \\
$24-2,35-37$ & 214.0 & 5.26 & 2.17 & 0.69 \\
$24-2,128-130$ & 214.9 & 5.29 & 2.27 & 0.37 \\
\hline
\end{tabular}

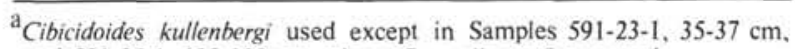
and $591-25-1,128-130 \mathrm{~cm}$, where $C$. wuellerstorfi was used. 


\begin{tabular}{ccccc}
\hline $\begin{array}{c}\text { Core-Section } \\
\text { (interval in cm) }\end{array}$ & $\begin{array}{c}\text { Sub-bottom } \\
\text { depth } \\
(\mathrm{m})\end{array}$ & $\begin{array}{c}\text { Age } \\
\text { (Ma) }\end{array}$ & $\begin{array}{c}\delta^{18} \mathrm{O} \\
\left({ }^{\circ} / 0 \mathrm{PDB}\right)\end{array}$ & $\begin{array}{c}\delta^{18} \mathrm{O} \\
\left({ }^{13} \mathrm{oo} \mathrm{PDB}\right) \\
\delta^{13} \mathrm{C}\end{array}$ \\
\hline
\end{tabular}

\section{Hole 591 (Cont.)}

\begin{tabular}{|c|c|c|c|c|}
\hline $24-3,35-37$ & 215.5 & 5.30 & 2.19 & 0.48 \\
\hline $24-3,128-130$ & 216.4 & 5.32 & 2.23 & 0.75 \\
\hline $24-4,35-37$ & 217.0 & 5.33 & 2.35 & 0.83 \\
\hline $24-4,128-130$ & 217.9 & 5.36 & 2.61 & 0.33 \\
\hline $24-5,25-27$ & 218.5 & 5.37 & 2.21 & 0.71 \\
\hline $24-5,128-130$ & 219.4 & 5.40 & 2.09 & 0.59 \\
\hline $24-6,35-37$ & 220.0 & 5.41 & 2.27 & 0.80 \\
\hline $24, \mathrm{CC}$ & 221.5 & 5.45 & 2.30 & 0.62 \\
\hline $25-1,35-37$ & 221.9 & 5.46 & 2.23 & 0.52 \\
\hline $25-1,128-130$ & 222.8 & 5.48 & 2.36 & 0.38 \\
\hline $25-2,35-37$ & 223.4 & 5.50 & 2.21 & 0.57 \\
\hline $25-2,128-130$ & 224.3 & 5.52 & 2.27 & 0.80 \\
\hline $25-3,35-37$ & 224.9 & 5.53 & 2.09 & 0.67 \\
\hline $25-3,128-130$ & 225.8 & 5.56 & 2.11 & 0.34 \\
\hline $25-4,35-37$ & 226.4 & 5.57 & 2.44 & 0.33 \\
\hline $25-4,128-130$ & 227.3 & 5.59 & 2.19 & 0.44 \\
\hline $25-5,35-37$ & 227.9 & 5.61 & 2.39 & 0.58 \\
\hline $25-5,128-130$ & 228.8 & 5.63 & 2.31 & 0.48 \\
\hline $25-6,35-37$ & 229.4 & 5.65 & 2.33 & 0.68 \\
\hline $25-6,128-130$ & 230.3 & 5.67 & 2.45 & 0.69 \\
\hline $25, \mathrm{CC}$ & 231.1 & 5.69 & 2.30 & 0.78 \\
\hline $26-1,35-37$ & 231.5 & 5.70 & 2.18 & 0.60 \\
\hline $26-1,128-130$ & 232.4 & 5.72 & 2.26 & 0.45 \\
\hline $26-2,35-37$ & 233.0 & 5.74 & 2.24 & 0.57 \\
\hline $26-2,128-130$ & 233.9 & 5.76 & 2.36 & 0.37 \\
\hline $26-3,35-37$ & 234.5 & 5.77 & 2.04 & 0.47 \\
\hline $26-3,128-130$ & 235.4 & 5.80 & 2.22 & 0.51 \\
\hline $26-4,35-37$ & 236.0 & 5.81 & 2.24 & 0.37 \\
\hline $26-4,128-130$ & 236.9 & 5.83 & 2.22 & 0.60 \\
\hline $26-5,35-37$ & 237.5 & 5.85 & 2.31 & 0.65 \\
\hline $26, \mathrm{CC}$ & 240.7 & 5.93 & 2.33 & 0.64 \\
\hline $27-1,35-37$ & 241.0 & 5.94 & 2.02 & 0.59 \\
\hline $27-1,128-130$ & 242.0 & 5.96 & 2.07 & 0.49 \\
\hline $27-2,35-37$ & 242.5 & 5.97 & 2.26 & 0.39 \\
\hline $27-2,128-130$ & 243.5 & 6.00 & 2.46 & 0.59 \\
\hline $27-3,35-37$ & 244.0 & 6.01 & 2.33 & 0.49 \\
\hline $27-3,128-130$ & 245.0 & 6.03 & 2.29 & 0.40 \\
\hline $27-4,35-37$ & 245.5 & 6.05 & 2.26 & 0.35 \\
\hline $27-4,128-130$ & 246.5 & 6.07 & 2.27 & 0.26 \\
\hline $27-5,35-37$ & 247.0 & 6.08 & 2.18 & 0.19 \\
\hline $27-5,128-130$ & 248.0 & 6.11 & 2.33 & 0.39 \\
\hline $27-6,35-37$ & 248.5 & 6.12 & 2.24 & 0.51 \\
\hline $27-6,128-130$ & 249.5 & 6.15 & 2.22 & 0.32 \\
\hline $27, \mathrm{CC}$ & 250.3 & 6.17 & 2.20 & 0.53 \\
\hline $28-1,35-37$ & 250.6 & 6.17 & 2.32 & 0.28 \\
\hline $28-2,35-37$ & 252.5 & 6.22 & 2.40 & 0.67 \\
\hline $28-3,35-37$ & 253.6 & 6.25 & 2.33 & 0.49 \\
\hline $28-4,35-37$ & 255.1 & 6.33 & 2.28 & 0.47 \\
\hline $28-5,35-37$ & 256.7 & 6.43 & 2.22 & 0.62 \\
\hline $28-6,35-37$ & 258.7 & 6.52 & 2.26 & 0.49 \\
\hline $29-1,35-37$ & 260.2 & 6.63 & 2.22 & 0.37 \\
\hline $29-2,35-37$ & 261.7 & 6.72 & 2.21 & 0.76 \\
\hline $29-3,35-37$ & 263.2 & 6.81 & 2.10 & 0.59 \\
\hline $29-4,35-37$ & 264.7 & 6.90 & 2.10 & 0.60 \\
\hline $29-5,35-37$ & 266.2 & 6.98 & 2.12 & 0.60 \\
\hline $29-6,35-37$ & 267.7 & 7.07 & 2.22 & 0.80 \\
\hline $29, \mathrm{CC}$ & 269.3 & 7.17 & 2.31 & 0.93 \\
\hline $30-1,35-37$ & 269.7 & 7.19 & 2.25 & 0.66 \\
\hline $30-2,35-37$ & 271.2 & 7.28 & 2.15 & 0.80 \\
\hline $30-3,35-37$ & 272.7 & 7.37 & 2.01 & 0.89 \\
\hline $30, \mathrm{CC}$ & 274.3 & 7.46 & 2.33 & 0.80 \\
\hline $31-1,35-37$ & 274.7 & 7.48 & 2.09 & 0.83 \\
\hline $31-2,35-37$ & 276.2 & 7.57 & 2.12 & 0.75 \\
\hline $31-3,35-37$ & 277.7 & 7.66 & 2.09 & 0.85 \\
\hline $31-4,35-37$ & 279.2 & 7.75 & 1.95 & 0.95 \\
\hline $31-5,35-37$ & 280.7 & 7.83 & 2.04 & 0.86 \\
\hline $31-6,35-37$ & 282.2 & 7.92 & 2.08 & 0.80 \\
\hline $31, \mathrm{CC}$ & 283.1 & 7.97 & 2.31 & 0.85 \\
\hline
\end{tabular}

Core-Section

Sub-bottom (interval in cm)

Hole 591B

$1-1,35-37$

$1-2,35-37$

$1-3,35-37$

$1, \mathrm{CC}$

2-1, 35-37

$2-2,35-37$

$2-3,35-37$

$2, \mathrm{CC}$

3-1, 35-37

3-2, 35-37

$3-3,35-37$

$3-5,35-37$

$3, \mathrm{CC}$

4-1, 35-37

$4-2,35-37$

$4-3,35-37$

$4-4,35-37$

4-5, 35-37

$4, \mathrm{CC}$

5-1, 35-37

5-2, 35-37

$5-3,35-37$

$5-4,35-37$

6-1, 35-37

6-2, 35-37

6-3, 35- 37

$6-4,35-37$

6-5, 35-37

$6, \mathrm{CC}$

$7-1,35-37$

$7-1,35-37$

$7-2,35-37$

$7-3,35-37$

$7-4,35-37$

$7-5,35-37$

$7-6,35-37$

$7, \mathrm{CC}$

8-2, 35-37

$8, \mathrm{CC}$

9-2, 35-37

$9, \mathrm{CC}$

$10-1,35-37$

$10-2,35-37$

$10-3,35-37$

$11-1,35-37$

$11, \mathrm{CC}$

$12-1,35-37$

$12-2,35-37$

$12, \mathrm{CC}$

$13-1,35-37$

$13-2,35-37$

$13, \mathrm{CC}$

14-1, 35- 37

$14-2,35-37$

$14-6,35-37$

$14, \mathrm{CC}$

$15-1,35-37$

$15-3,35-37$

$17-1,35-37$

17-2, 35-37

$17-3,35-37$

$17-4,35-37$

$18-1,35-37$

$18-2,35-37$

$18-3,35-37$

$18-4,35-37$

$18-5,35-37$

$18-6,35-37$

$19-1,35-37$

$19-2,35-37$

$19-4,35-37$

$19-5,35-37$

$20-1,35-37$

$20-2,35-37$

$20-3,35-37$

$20-5,35-37$

$21-1,35-37$

272.5

274.0

280.2

280.5

282.0
283.5

289.8

290.2

292.0

293.2

296.2

299.4
299.8

301.3

302.8

304.3

305.8

308.8

309.2

310.7

312.2

313.7
318.5

320.0

321.5

323.0
324.5

324.5
327.6

328.0

328.0

329.5

331.0

332.5

335.5

337.2

339.0
346.8

346.8

348.7

356.4

356.8

358.3

359.8

366.3

375.6

376.0

377.3
385.2

385.5

387.0

394.8

395.2

396.7

402.7

404.4
404.8

404.8

407.8

424.0

425.5

427.0

428.5

433.5

435.0

436.5

438.0

439.5

441.0

443.2

444.7

447.7

449.2

452.8

454.3

455.8

458.8
462.3

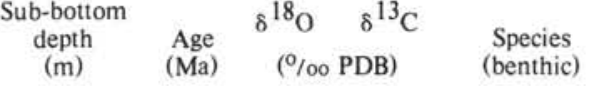

\section{$\begin{array}{ll}7.27 & 2.29\end{array}$}

$\begin{array}{ll}7.35 & 2.22 \\ 7.44 & 2.23\end{array}$

$\begin{array}{ll}7.80 & 2.04\end{array}$

$\begin{array}{ll}7.82 & 2.15\end{array}$

$\begin{array}{ll}7.91 & 2.20 \\ 8.00 & 1.95\end{array}$

$8.37 \quad 2.03$

$\begin{array}{ll}8.39 & 2.17\end{array}$

$8.50 \quad 1.96$

$8.57 \quad 1.05$

$8.74 \quad 2.10$

$8.93 \quad 2.17$

$\begin{array}{ll}8.95 & 2.38\end{array}$

$9.04 \quad 2.21$

$9.13 \quad 2.34$

\begin{tabular}{l}
$9.22 \quad 2.19$ \\
\hline
\end{tabular}

$9.30 \quad 2.34$

$9.48 \quad 2.20$

$\begin{array}{ll}9.50 & 2.34\end{array}$

$\begin{array}{ll}9.56 & 2.33\end{array}$

$9.62 \quad 2.27$

$\begin{array}{ll}9.67 & 2.38\end{array}$

$\begin{array}{ll}9.86 & 2.03\end{array}$

$9.91 \quad 2.40$

$9.97 \quad 2.29$

$10.03 \quad 2.35$

$10.08 \quad 2.29$

$10.20 \quad 2.21$

$10.22 \quad 2.24$

$10.22 \quad 2.24$

$10.27 \quad 2.15$

$10.33 \quad 2.02$

$10.39 \quad 2.09$

$10.44 \quad 2.23$

$\begin{array}{ll}10.50 & 2.29\end{array}$

$10.57 \quad 2.44$

$10.63 \quad 2.09$

$10.93 \quad 2.30$

$11.00 \quad 2.10$

$\begin{array}{ll}11.44 & 2.12 \\ 11.46 & 1.74\end{array}$

$\begin{array}{ll}11.55 & 1.89\end{array}$

$11.63 \quad 2.14$
1.00

$12.00 \quad 2.08$

$\begin{array}{ll}12.19 & 1.81\end{array}$

$\begin{array}{ll}12.20 & 1.42 \\ 12.26 & 1.98\end{array}$

$\begin{array}{ll}12.26 & 1.98 \\ 12.63 & 2.01\end{array}$

$12.64 \quad 1.84$

$12.61 \quad 2.12$

$\begin{array}{ll}13.07 & 1.90 \\ 13.09 & 1.95\end{array}$

$\begin{array}{ll}13.16 & 1.85\end{array}$

$13.44 \quad 1.32$

$\begin{array}{ll}13.51 & 1.77\end{array}$

$\begin{array}{ll}13.53 & 2.12\end{array}$

$\begin{array}{ll}13.67 & 1.69\end{array}$

$\begin{array}{ll}14.42 & 1.82 \\ 14.49 & 1.61\end{array}$

$14.56 \quad 1.70$

$\begin{array}{ll}14.63 & 1.64 \\ 14.86 & 1.58\end{array}$

$\begin{array}{ll}14.93 & 1.33\end{array}$

$15.00 \quad 1.69$

$15.11 \quad 1.54$

$15.22 \quad 1.55$

$\begin{array}{ll}15.33 & 1.87\end{array}$

$15.49 \quad 1.62$

$\begin{array}{ll}15.60 & 1.36 \\ 15.83 & 1.41\end{array}$

$15.94 \quad 1.40$

$16.20 \quad 1.14$

$16.23 \quad 1.11$

$16.26 \quad 1.36$

$\begin{array}{ll}16.32 & 1.02 \\ 16.39 & 0.71\end{array}$
0.82 C. kullenbergi

0.95 C. kullenbergi

0.99 C. kullenbergi

0.78 C. kullenbergi

02 C. kullenbergi

0.98 C. kullenbergi

1.01 C. kullenbergi

0.84 C. kullenbergi

1.02 C. kullenbergi

1.11 C. kullenbergi

0.71 C. wuellerstorfi

.96 C. wuellerstorf

1.25 C. kullenbergi

1.19 C. kullenbergi

1.01 C. kullenbergi

1.03 C. kullenbergi

1.08 C. kullenbergi

0.97 C. wuellerstorfi

1.11 C. kullenbergi

1.14 C. kullenbergi

0.93 C. kullenbergi

1.00 C. kullenbergi

1.38 C. kullenbergi

1.10 C. kullenbergi

1.14 C. kullenbergi

1.33 C. kullenbergi

1.19 C. kullenbergi

1.18 C. kullenbergi

1.18 C. kullenbergi

0.95 C. kullenbergi

1.04 C. kullenbergi

0.99 C. kullenbergi

1.02 C. kullenbergi

0.98 C. kullenbergi

0.99 C. kullenbergi

0.82 C. kullenbergi

0.69 C. kullenbergi

0.79 C. wuellerstorfi

0.72 C. wuellerstorfi

0.85 C. wuellerstorfi

0.97 C. wuellerstorfi

1.10 C. wuellerstorfi

1.41 C. wuellerstorfi

0.96 C. kullenbergi

1.41 C. kullenbergi

1.13 C. kullenbergi

1.22 C. kullenbergi

0.94 C. kullenbergi

0.66 C. kullenbergi

0.97 C. kullenbergi

1.18 C. kullenbergi

0.86 C. kullenbergi

1.30 C. kullenbergi

0.87 C. kullenbergi

1.13 C. kullenbergi

1.03 C. kullentergi

1.25 C. kullenbergi

1.09 C. kullenbergi

1.54 C. kullenbergi

1.52 C. kullenbergi

1.35 C.wuellerstorfi

1.24 C.wuellerstorfi

1.52 C.wuellerstorfi 
MIOCENE TO PLIOCENE ISOTOPE STRATIGRAPHY, SOUTHWEST PACIFIC

\begin{tabular}{lccccc}
\hline $\begin{array}{c}\text { Core-Section } \\
\text { (interval in cm) }\end{array}$ & $\begin{array}{c}\text { Sub-bottom } \\
\text { depth } \\
(\mathrm{m})\end{array}$ & $\begin{array}{c}\text { Age } \\
(\mathrm{Ma})\end{array}$ & $\begin{array}{c}\delta^{18} \mathrm{O} \\
(\% \text { oo PDB })\end{array}$ & $\begin{array}{c}\delta^{13} \mathrm{C} \\
\text { Hole 591B (Cont.) } \\
\text { Holenthic) }\end{array}$ & $\begin{array}{c}\text { Species } \\
\text { (benthen }\end{array}$ \\
$21-2,35-37$ & 463.8 & 16.42 & 0.68 & 1.29 & O. umbonatus \\
$21-3,35-37$ & 465.3 & 16.45 & 0.80 & 1.49 & O. umbonatus \\
$22-1,35-37$ & 472.0 & 16.59 & 0.87 & 1.74 & O. umbonatus \\
$22-3,35-37$ & 475.0 & 16.65 & 0.99 & 1.91 & O. umbonatus \\
$22-4,35-37$ & 476.5 & 16.68 & 0.93 & 2.01 & O. umbonatus \\
$22-5,35-37$ & 478.0 & 16.71 & 1.04 & 2.28 & O. umbonatus \\
$22-6,35-37$ & 479.5 & 16.74 & 1.11 & 1.97 & O. umbonatus \\
$23-1,35-37$ & 481.5 & 16.78 & 0.92 & 1.87 & O. umbonatus \\
$23-2,35-37$ & 483.0 & 16.81 & 0.80 & 2.03 & O. umbonatus \\
$23-3,35-37$ & 484.5 & 16.84 & 0.30 & 1.54 & O. umbonatus \\
$23-4,35-37$ & 486.0 & 16.87 & 0.42 & 1.30 & O. umbonatus \\
$23-6,35-37$ & 489.0 & 16.93 & 0.62 & 1.82 & O. umbonatus \\
$24-2,35-37$ & 492.7 & 17.00 & 0.87 & 1.28 & O. umbonatus \\
$24-3,35-37$ & 494.2 & 17.03 & 0.69 & 1.63 & O. umbonatus \\
$24-4,35-37$ & 495.7 & 17.06 & 0.54 & 1.05 & O. umbonatus \\
\hline
\end{tabular}

